OPEN ACCESS

Edited by:

Ana Catarina Sousa, University of Evora, Portugal

Reviewed by: Yu Ait Bamai, Hokkaido University, Japan Vimalkumar Krishnamoorthi, NYU Grossman School of Medicine, United States

Chau-Ren Jung,

China Medical University, Taiwan

*Correspondence:

Yuki Ito yukey@med.nagoya-cu.ac.jp

Specialty section: This article was submitted to Obesity,

a section of the journal

Frontiers in Endocrinology

Received: 17 September 2021 Accepted: 23 October 2021

Published: 11 November 2021

Citation:

Mohanto NC, Ito $Y$, Kato $S$ and Kamijima M (2021) Life-Time Environmental Chemical Exposure and Obesity: Review of Epidemiological Studies Using Human Biomonitoring Methods.

Front. Endocrinol. 12:778737. doi: 10.3389/fendo.2021.778737

\section{Life-Time Environmental Chemical Exposure and Obesity: Review of Epidemiological Studies Using Human Biomonitoring Methods}

\author{
Nayan Chandra Mohanto, Yuki Ito *, Sayaka Kato and Michihiro Kamijima \\ Department of Occupational and Environmental Health, Nagoya City University Graduate School of Medical Sciences, \\ Nagoya, Japan
}

The exponential global increase in the incidence of obesity may be partly attributable to environmental chemical (EC) exposure. Humans are constantly exposed to ECs, primarily through environmental components. This review compiled human epidemiological study findings of associations between blood and/or urinary exposure levels of ECs and anthropometric overweight and obesity indices. The findings reveal research gaps that should be addressed. We searched MEDLINE (PubMed) for full text English articles published in 2006-2020 using the keywords "environmental exposure" and "obesity". A total of 821 articles were retrieved; 102 reported relationships between environmental exposure and obesity indices. ECs were the predominantly studied environmental exposure compounds. The ECs were grouped into phenols, phthalates, and persistent organic pollutants (POPs) to evaluate obesogenic roles. In total, 106 articles meeting the inclusion criteria were summarized after an additional search by each group of EC combined with obesity in the PubMed and Scopus databases. Dose-dependent positive associations between bisphenol $\mathrm{A}(\mathrm{BPA})$ and various obesity indices were revealed. Both individual and summed di(2-ethylhexyl) phthalate (DEHP) and non-DEHP metabolites showed inconsistent associations with overweight and obesity indices, although mono-butyl phthalate (MBP), mono-ethyl phthalate (MEP), and mono-benzyl phthalate (MBzP) seem to have obesogenic roles in adolescents, adults, and the elderly. Maternal exposure levels of individual POP metabolites or congeners showed inconsistent associations, whereas dichlorodiphenyldichloroethylene (DDE) and perfluorooctanoic acid (PFOA) were positively associated with obesity indices. There was insufficient evidence of associations between early childhood EC exposure and the subsequent development of overweight and obesity in late childhood. Overall, human evidence explicitly reveals the consistent obesogenic roles of BPA, DDE, and PFOA, but inconsistent roles of phthalate metabolites and other POPs. Further prospective studies may yield deeper insights into the overall scenario.

Keywords: environmental chemicals, phthalates, persistent organic pollutants, overweight, obesity, bisphenols, environmental obesogens, human biomonitoring 


\section{INTRODUCTION}

Obesity is characterized by excess body fat, total body fat, or a particular depot of body fat (1). The most commonly evaluated anthropometric indices of obesity are body mass index (BMI), waist circumference (WC), hip circumference (HC), skinfold thickness (ST), percent body fat (\%BF), fat mass (FM), and waistto-height ratio (WHtR) (2-5). An adult individual is overweight if BMI $\geq 25 \mathrm{~kg} / \mathrm{m}^{2}$ to $<30 \mathrm{~kg} / \mathrm{m}^{2}$, and obese if $\mathrm{BMI} \geq 30 \mathrm{~kg} / \mathrm{m}^{2}$ or $\mathrm{WC} \geq 80 \mathrm{~cm}$ in women and WC $\geq 90 \mathrm{~cm}$ in men (6). Childhood overweight and obesity can be defined as BMI z-scores $>1$ and $>2$, respectively $(3,4,6)$. Sex- and age-specific WC $\geq 90^{\text {th }}$ percentile or WHtR $\geq 0.5$ are also used to determine obesity in children $(7,8)$. Some alternative measurements are still available for both children and adults, and differ with age, gender, and country (9).

Whether obesity should be declared a disease is controversial (1). However, obesity leads to many aspects of ill health or functional impairment and several diseases (10-13), reduces health quality of life $(14,15)$, and increase mortality and morbidity (16-18). It is a complex condition with many causal contributors, including genetic factors and environmental factors (19-21). Recent epidemiological research has also reported the associations with overweight and obesity of environmental exposure sources that include environmental chemicals (ECs), air pollution, particulate matter, heavy metals, noise, green space, and others (22-31). According to the "obesogen hypothesis," ECs, which are termed environmental obesogens (EOs), regulate lipid metabolism and adipogenesis, leading to obesity (32).

Over time, the use of synthetic chemicals has grown exponentially with the development of commerce and industry (33). Excessive usage results in environmental contamination. Humans are exposed to these ECs through environmental media by ingestion, inhalation, absorption, and even through transplacental transfer and breast milk (34-42). The human exposure levels of these ECs are generally estimated by biomonitoring of their metabolites or parent compounds in human urine or blood (cord blood or peripheral blood) as exposure biomarkers worldwide (43-47).

Recently, there has been increased interest in epidemiological studies of EC biomonitoring and subsequent evaluation of their obesogenic effects $(4,8,34,48-51)$. A concise view of the overall

\footnotetext{
Abbreviations: BF, body fat; BMI, body mass index; BPA, bisphenol A; BPF, bisphenol F; BPS, bisphenol S; $\beta$-HCH, beta-hexachlorocyclohexane; DBP, dibutyl phthalate; DDT, dichlorodiphenyltrichloroethane; DDE, dichlorodiphenyldichloroethylene; DEHP; di(2ethylhexyl) phthalate; EC, environmental chemical; EO, environmental obesogen; FM, fat mass; HC, hip circumference; HCB, hexachlorobenzene; HMWP, high molecular weight phthalate; LMWP, low molecular weight phthalate; MBP, mono-butyl phthalate/ mono-n-butyl phthalate; MBzP, mono-benzyl phthalate; MCMHP, mono-2carboxymethyl-hexyl phthalate; MCPP, mono-(3-carboxypropyl) phthalate; MEP, mono-ethyl phthalate; MEHP, mono-2-ethylhexyl phthalate; MEOHP, mono (2ethyl-5-exohexyl) phthalate; MEHHP, mono (2-ethyl-5hydroxyhexyl) phthalate; MEHP, mono-ethylhexyl-phthalate; MECPP, mono-(2-ethyl-5-carboxypentyl) phthalate; MiBP, mono-isobutyl phthalate; MMP, mono-methyl phthalate; OC, organochlorine compound; PBDEs, polybrominated diphenyl ethers; $\mathrm{PCB}$, polychlorinated biphenyl; PFAS, per- and polyfluoroalkyl substances; POPs, persistent organic pollutants; ST, skinfold thickness; WC, waist circumference; WHtR, waist-toheight ratio; WtHR, weight-to-height ratio.
}

epidemiological findings is required to clarify whether obesogenic evidence of ECs is sufficient or consistent for the advancement of future research. Some previous reviews have explored the obesogenic role of ECs. However, most of these considered only a single group of ECs, and/or selected ECs based on their endocrine-disrupting properties, and/or considered limited exposure and outcome assessment period or age, and even not focused on epidemiological studies, and/or focused on a mechanism (52-59).

A further review addressing the current epidemiological evidence of the obesogenic effects of ECs at all stages of life from a public health perspective is needed. Accordingly, the objectives of the present review are to illuminate epidemiological study findings of the associations between EC exposure and anthropometric overweight and obesity indices, uncover the current research gap, and contemplate future research.

\section{METHODS}

\section{Selection and Grouping of EOs}

Research articles that demonstrated the associations between environmental exposure and obesity in MEDLINE of PubMed were searched for using "environmental exposure" AND "obesity" as keywords to select EOs (Figure 1). After additional filtering for full text, journal articles, inclusion of humans, English, and publication year (2006-2020), a total of 821 articles were retrieved. Of these, 719 articles were excluded owing to the following reasons: abstract not available $(n=10)$; involved clinical trials $(n=7)$, review/systematic review/metaanalysis $(n=299)$; cell line studies $(n=12)$; animal studies and statistical/computational models $(n=21)$; editorial/commentary/ protocol and approach $(\mathrm{n}=19)$; investigated associations of EC exposure with other adverse outcomes, including hypertension, puberty, diabetes, polycystic ovary syndrome, cardiovascular diseases, cancer risk, and others, and simple biomonitoring and ecological studies $(n=351)$. In the remaining 102 articles, the ECs were predominantly studied environmental exposure $(\mathrm{ECs}=62$ and others $=40)$. Also, the production and uses of agricultural, industrials, and other synthetic chemicals are increasing, and recognized as major environmental pollutants over other environmental exposures namely heavy metals, noise or sound, green space and particulate matters. Therefore, we selected ECs as the major EOs apart from other environmental exposure and grouped them as follows: (i) phenols [bisphenol A (BPA), bisphenol S (BPS), bisphenol F (BPF), and others], (ii) phthalates (all phthalates and their metabolites), and (iii) persistent organic pollutants (POPs) [organochlorine compounds (OCs), polybrominated diphenyl ethers (PBDEs) and per- and polyfluoroalkyl substances (PFASs), and their metabolites or congeners] (Figure 1).

\section{Literature Search and Inclusion Criteria}

A primary search in PubMed and Scopus databases for each group of EO used the keywords "bisphenols" AND "obesity," "phthalate" AND "obesity", and "persistent organic pollutants" 


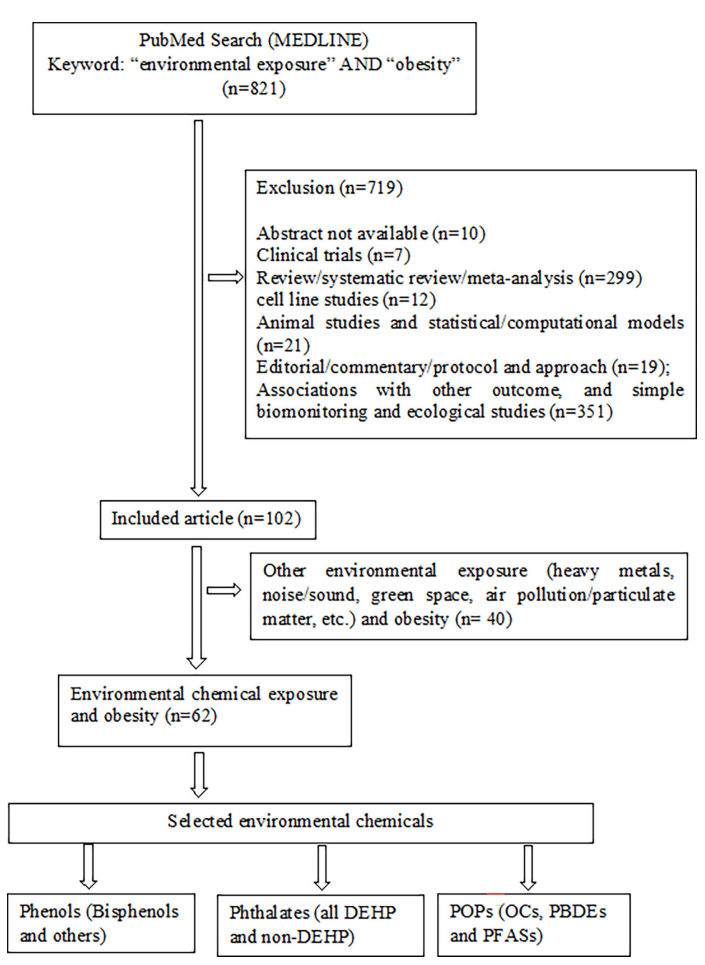

FIGURE 1 | Schematic diagram of the strategy for selection and grouping of environmental obesogens.

AND "obesity" to identify original research articles of human epidemiological studies. Additional PubMed filtering and Scopus refining were performed to select relevant articles (Figure 2). Articles were considered relevant when they investigated the associations of selected EOs with anthropometric overweight and obesity indices. The references of the selected primary research articles were also searched for relevant publications. A secondary search was also performed for each group of POPs combined with obesity (Figure 2).

All full-length articles, short communications, and brief reports of original research work from all over the world, irrespective of sex, religion, and race/ethnicity, were included in this review (Figure 1). Inclusion criteria included (i) epidemiological study (cohort, cross-sectional, and casecontrol); (ii) all ages and/or life-stage at exposure or outcome assessment; (iii) primary outcomes of overweight and/or obesity, or at least one anthropometric index of overweight or obesity; (iv) EO concentrations measured in urine or blood as human biomonitoring; (v) assessment of only non-occupational exposure levels of EOs; (vi) published after postulating "obesogen hypothesis"; and (vii) written in English. All other articles were excluded (Figure 2). Finally, 106 original research articles were included in this review.

\section{Visualizing Evidence}

Associations of EOs with overweight and/or obesity have been demonstrated in the aforementioned three groups. We grouped

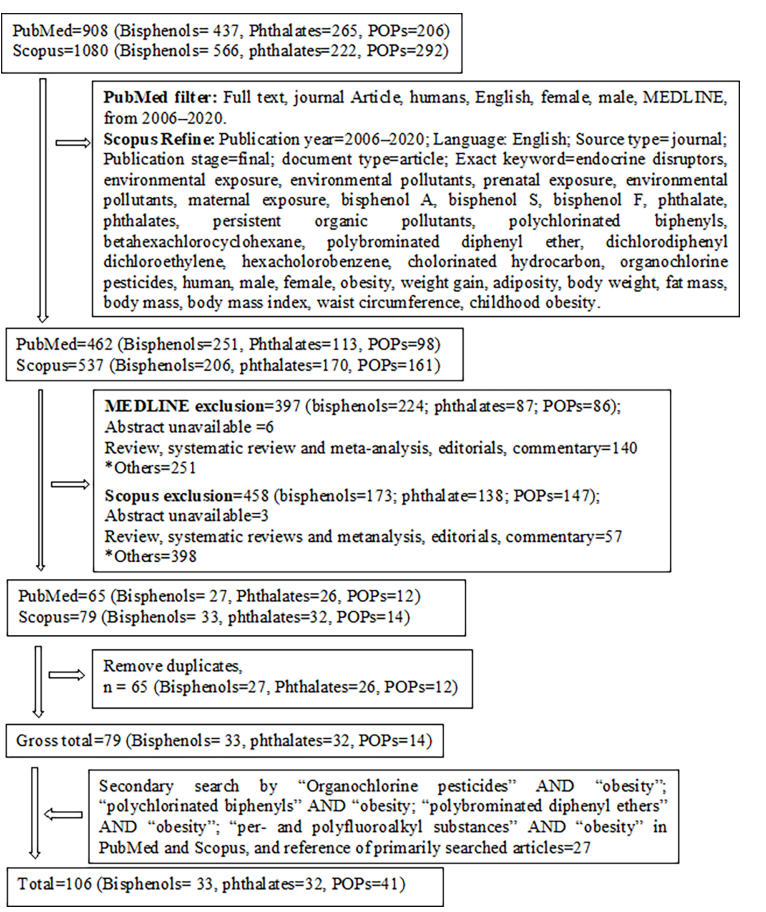

FIGURE 2 | Schematic diagram of study selection. *Cell line studies, animal/ rodent/drosophila studies, investigation of other associations (e.g., growth, metabolic syndrome, fatty liver disease, diabetes, cardiometabolic risk, inflammation, polycystic ovary syndrome, prostate cancer, food intake, semen quality, puberty), ecological studies, and or simple biomonitoring studies.

the early- and later-life exposure and outcome assessment age into seven categories (Matrix Tables 1-6): infants (up to 1 year), toddlers ( $>1-2$ years), preschoolers $(>2-5$ years), school-aged $(>5-13$ years), adolescents ( $>13-19$ years), adults $(\geq 20-60$ years), and elderly (>60 years) as classified previously (60). Matrix tables were created according to categories.

\section{RESULTS}

\section{Environmental Phenols and Obesity}

We summarized a total of 33 human epidemiological studies, including 13 cohort studies and 20 cross-sectional studies that explored the association between prenatal and early- to later-life urinary phenols, especially bisphenol exposure levels with anthropometric overweight and obesity indices (Table 1 and Matrix Table 1). Most of the cohort studies were birth cohorts. The study subjects enrolled in the birth cohorts ranged from 173 to 1128 mother-child pairs. Among the 20 cross-sectional studies, 9 involved children and adolescents between the ages of 3 and 19 years, and 11 involved adults and elderly participants $>18$ years. Both the cohort and cross-sectional studies measured BPA, BPS, and BPF in spot urine other than the first morning void urine, or $24 \mathrm{~h}$ urine.

Maternal urinary BPA levels showed null or positive associations with one or more anthropometric obesity indices 
TABLE 1 | Associations of environmental phenols with anthropometric overweight and obesity indices.

\begin{tabular}{|c|c|c|c|c|c|c|}
\hline \multirow[t]{2}{*}{ Ref. } & \multirow{2}{*}{$\begin{array}{l}\text { Study type } \\
\text { (country), } \\
\text { Subjects (n) }\end{array}$} & \multicolumn{2}{|c|}{ Exposure } & \multirow{2}{*}{$\begin{array}{l}\text { Outcome } \\
\text { ass. time }\end{array}$} & \multirow[t]{2}{*}{ Covariates } & \multirow[t]{2}{*}{ Key findings } \\
\hline & & Marker & $\begin{array}{l}\text { Biomonitoring } \\
\text { time }\end{array}$ & & & \\
\hline (8) & $\begin{array}{l}\text { Birth cohort } \\
\text { (China), } \\
\text { Mother-child } \\
(430)\end{array}$ & BPA & $\begin{array}{l}40 \text { (mean) GW, } \\
3 \text { y, } 7 \text { y }\end{array}$ & $7 \mathrm{y}$ & $\begin{array}{l}1 \mathrm{a}, 2 \mathrm{a}, 3 \mathrm{a} \\
4 \mathrm{a}, 5 \mathrm{a}, 6 \mathrm{a} \\
7 \mathrm{a}, 16 \mathrm{a}\end{array}$ & $\begin{array}{l}\text { - Maternal urinary BPA concentration (range: } 0.17-280 \mu \mathrm{g} / \mathrm{l}) \text { was associated with } \\
\text { WC in children aged } 7 \mathrm{y}[\beta=0.51(0.07,0.95)] \text {. Positive associations were } \\
\text { observed only in girls }[\beta=0.69(0.04,1.34)] \text { not in boys. } \\
\text { Risk of } A O \text { related to prenatal BPA exposure was higher in the } \mathrm{T} 2 \text { and the T3 } \\
\text { than those in the } \mathrm{T} 1[\mathrm{OR}=2.51(1.15,5.50) \text { and } \mathrm{OR}=2.58(1.19,5.63) \text {, } \\
\text { respectively]. No significant associations with } \mathrm{GO} \text { were evident at } 7 \mathrm{y} \text {. } \\
\text { Risk of } \mathrm{AO} \text { at } 7 \mathrm{y} \text { in } \mathrm{T} 3 \text { of early childhood }(3 \mathrm{y}) \mathrm{BPA} \text { exposure was higher than } \\
\text { those in } \mathrm{T} 1[\mathrm{OR}=2.86(1.02,8.04)] \text {. }\end{array}$ \\
\hline$(2)$ & $\begin{array}{l}\text { Cross- } \\
\text { sectional } \\
\text { (Korea), } \\
\text { Adults (702) }\end{array}$ & BPA & 40.1 y (mean) & $40.1 y$ & $\begin{array}{l}1,2,7,8 \\
\quad 9 a\end{array}$ & $\begin{array}{l}\text { - Urinary BPA levels were not associated with GO risk. Participants in the Q4 of } \\
\text { BPA level had } 1.75 \text { times higher risk of } A O \text { than participants in the Q1 of BPA } \\
\text { level. } \\
\text { Urinary BPA level significantly associated with } \mathrm{AO} \text { in women }[\mathrm{OR}=1.50(1.00 \text {, } \\
2.26)] \text { but not in men }[\mathrm{OR}=1.13(0.85,1.50)] \text {. Also, the association was } \\
\text { significant in postmenopausal women }[\mathrm{OR}=2.23(1.01,4.92)] \text { but non-significant } \\
\text { in premenopausal women }[\mathrm{OR}=1.31(0.78,2.20)] \text {. }\end{array}$ \\
\hline (50) & $\begin{array}{l}\text { Birth cohort } \\
\text { (Netherlands), } \\
\text { Mother-child } \\
(1128)\end{array}$ & $\begin{array}{l}\text { BPA, BPS, } \\
\text { BPF }\end{array}$ & $1^{\text {st }}-3^{r d} T_{r}$ & $10 y$ & $\begin{array}{c}1 \mathrm{ab}, 2 \mathrm{a} \\
3 \mathrm{a}, 5 \mathrm{a}, 6 \mathrm{c} \\
7 \mathrm{~b}, 8,10 \mathrm{a} \\
11 \mathrm{a}\end{array}$ & $\begin{array}{l}\text { - Null associations were evident between maternal bisphenol concentrations and } \\
\text { childhood adiposity measures at } 10 \mathrm{y} \text {. }\end{array}$ \\
\hline (61) & $\begin{array}{l}\text { Birth cohort } \\
\text { (Canada), } \\
\text { Mother-child } \\
\text { (719) }\end{array}$ & BPA & 6.3-15 GW & $1.9-6.2$ y & $\begin{array}{c}1 b, 3 a, 4 a \\
5 a, 7 b \\
10 a, 12 \\
13 a\end{array}$ & $\begin{array}{l}\text { - A 2-fold increase in BPA concentrations (range: } 0.1-63 \mathrm{ng} / \mathrm{ml}) \text { was associated } \\
\text { with higher waist to hip ratio }[\beta=0.003(0.001,0.005)] \text { among overall child. } \\
\text { A 2-fold increase in BPA concentrations was associated with increased WC } \\
{[\beta=0.20(0.00,0.50)] \text { and subscapular ST }[\beta=0.15(0.01,0.30)] \text { in girls. }} \\
\text { Associations were null in boys. }\end{array}$ \\
\hline$(48)$ & $\begin{array}{l}\text { Cross- } \\
\text { sectional } \\
\text { (USA), Adults } \\
(1269)\end{array}$ & $\begin{array}{l}\text { BPA, BPS, } \\
2,4-\mathrm{DP}, 2,5- \\
\text { DP }\end{array}$ & $\geq 20 y$ & $\geq 20 y$ & $\begin{array}{l}1,2,3,4 b \\
6 b, 7,9 b \\
10 a, 16 a\end{array}$ & $\begin{array}{l}\text { - BPS was associated with both } \mathrm{GO}[\mathrm{OR}=1.44(1.01,2.07)] \text { and } \mathrm{AO}[\mathrm{OR}=1.47 \\
(1.01,2.16)](\mathrm{Q} 4 \text { vs. Q1) whereas } \mathrm{BPA} \text { showed nonsignificant associations with } \\
\mathrm{GO}[\mathrm{OR}=1.53(0.99,2.35)] \text { and } \mathrm{AO}[\mathrm{OR}=1.36(0.87,2.13)] \text {. } \\
\text { - There were no associations of 2,4-DP and 2,5-DP with } \mathrm{GO} \text { and } \mathrm{AO} \text {. }\end{array}$ \\
\hline (62) & $\begin{array}{l}\text { Cross- } \\
\text { sectional } \\
\text { (Iran), } \\
\text { Children, } \\
\text { adolescents } \\
(132)\end{array}$ & BPA & $6-18$ y & $6-18$ y & $\begin{array}{l}1,2,9 b \\
16 a\end{array}$ & $\begin{array}{l}\text { - The mean BMl increased significantly from T1 to T3 (T1: 8.70-78.90, T2: 82.70- } \\
246.80 \text { and T3: } 247-725 \mu \mathrm{g} / \mathrm{l}) \text {; [T2: difference=3.65 }(1.92,5.38) \text { and T3: } \\
\text { difference=8.26 }(6.48,10.03) \text { vs T1, respectively]. Similarly, consistent } \\
\text { association also found between BPA levels and WC }[7.97(3.64,12.31) \text { and } \\
16.26 \text { (11.81, } 20.72) \text { at T2 and T3, respectively]. } \\
\text { Participants in the T2 and T3 had higher odds for obesity [OR=4.11 (1.56, } \\
\text { 10.81) and OR=12.48 (3.36, 46.39), respectively], in comparison with T1. }\end{array}$ \\
\hline (63) & $\begin{array}{l}\text { Cross- } \\
\text { sectional } \\
\text { (USA), } \\
\text { Children (NA) }\end{array}$ & BPA & $6 y, 19 y$ & $6 y, 19 y$ & $\begin{array}{l}1,2,3 a \\
4 b c, 6 b \\
9 c, 10 a \\
16 a\end{array}$ & $\begin{array}{l}\text { - Increase odds of obesity were found among the Q2 [OR=1.25 }(0.95,1.65)], \mathrm{Q} 3 \\
{[\mathrm{OR}=1.39(1.03,1.86)] \text { and } \mathrm{Q} 4[\mathrm{OR}=1.43(1.11,1.84)] \text { compared with } \mathrm{Q} 1 \text { before }} \\
\text { creatinine adjustment. After the adjustment, the associations were null; Q2 } \\
{[\mathrm{OR}=0.83(0.66,1.03)], \mathrm{Q} 3[\mathrm{OR}=0.91(0.70,1.18)] \text { and } \mathrm{Q} 4[\mathrm{OR}=0.95(0.74,} \\
1.21)] \text {. } \\
\text { Children enrolled in 2003-2008 with higher urinary BPA concentrations had } \\
\text { elevated odds of obesity, whereas these associations were inconsistent who } \\
\text { enrolled during 2009-2014. }\end{array}$ \\
\hline (34) & $\begin{array}{l}\text { Cross- } \\
\text { sectional } \\
\text { (USA), } \\
\text { Children, } \\
\text { adolescents } \\
\text { (1831) }\end{array}$ & $\begin{array}{l}\text { BPA, BPS, } \\
\text { BPF }\end{array}$ & $6-19 y$ & $6-19 y$ & $\begin{array}{l}1,2,3,4 b \\
10 a\end{array}$ & $\begin{array}{l}\text { - A 10-fold increase in BPS, the odds of } \mathrm{GO} \text { increased by } 16 \%[\mathrm{OR}=1.16(1.02 \text {, } \\
\text { 1.32)], severe obesity by } 18 \%[\mathrm{OR}=1.18(1.03,1.35)] \text {, and } \mathrm{AO} \text { by } 13 \% \\
{[\mathrm{OR}=1.13(1.02,1.27)] \text {. }} \\
\text { - Detected BPF (detected } v \text { s not detected) concentration was associated with an } \\
\text { increased prevalence of } \mathrm{AO}[\mathrm{OR}=1.29(1.01,1.64)] \text { and continuous } \mathrm{BMIZ} \\
{[\beta=0.10(0.01,0.20)] \text {. }} \\
\text { - } \mathrm{BPA} \text { was not associated with obesity. }\end{array}$ \\
\hline$(7)$ & $\begin{array}{l}\text { Cross- } \\
\text { sectional } \\
\text { (USA), } \\
\text { Children, } \\
\text { adolescents } \\
\text { (745) }\end{array}$ & $\begin{array}{l}\text { BPA, BPF, } \\
\text { BPS }\end{array}$ & $6-17$ y & $6-17$ y & $\begin{array}{l}1,2,4 b \\
6 b d, 9 c \\
10 a, 16 a\end{array}$ & $\begin{array}{l}\text { - The OR of GO comparing the Q4 with Q1 of urinary bisphenol levels were [1.74 } \\
(0.92,3.31)] \text { for BPA (3.98 vs } 0.46 \mathrm{ng} / \mathrm{ml}),[1.54(1.02,2.32)] \text { for BPF }(1.55 \mathrm{vs} \\
0.14 \mathrm{ng} / \mathrm{ml}) \text {, and }[1.36(0.53,3.51)] \text { for BPS }(1.30 \mathrm{vs} 0.07 \mathrm{ng} / \mathrm{ml}) \text {. } \\
\text { - Urinary BPA, BPF, and BPS levels }(\mathrm{Q} 4) \text { were significantly associated with both } \\
\text { GO and AO only in girls. } \\
\text { - The weighted prevalence of GO and AO were } 21 \%(15.5,26.4) \text { and } 35 \%(28.2 \text {, } \\
\text { 41.9). }\end{array}$ \\
\hline (64) & $\begin{array}{l}\text { Cross- } \\
\text { sectional }\end{array}$ & BPA & $18-79$ y & $18-79$ y & $\begin{array}{l}1,2,8 \\
10 a, 16 a \\
\quad 6 e f\end{array}$ & $\begin{array}{l}\text { - Urinary BPA concentrations was associated with increased odds of GO } \\
{[\mathrm{OR}=1.54(1.002,2.37)] \text { and } \mathrm{AO}[\mathrm{OR}=1.16(0.81,1.66)] \text { in the Q4 }(>2.4 \mu \mathrm{g} / \mathrm{l}) \mathrm{vs} \text {. }} \\
\mathrm{Q} 1(<0.7 \mu \mathrm{g} / \mathrm{l}) \text {. }\end{array}$ \\
\hline
\end{tabular}


TABLE 1 | Continued

\begin{tabular}{cccc}
\hline Ref. & $\begin{array}{c}\text { Study type } \\
\text { (country), } \\
\text { Subjects }(\mathrm{n})\end{array}$ & Marker & $\begin{array}{c}\text { Exposure } \\
\text { Biomonitoring } \\
\text { time }\end{array}$
\end{tabular}

(Canada),

Adults (4733)

(65) Cross-

sectional

(Korea),

Female (296)

(66) Cross-

sectional

(USA),

Children

(1860)

(67) Cros

sectional

(USA), Adults

(1709)

(68) Cohort (USA), Girls (1017)

BPA, 2,5-

DP,

Triclosan,

enterolactone

(69) Cohort

(China), Adults

(888)

(70) Birth cohort

(Mexico),

Mother-child

(249)

(71) Birth cohort

(USA),

BPA, 2,5-

Mother-child

DP, BeP-3,

(173)

Triclosan

(72) Birth cohort BPA

(USA), Mother

(375) children

(408 \& 518) $5 b, 6 b, 7 c$ 9cd, 10a, $16 a b$

$16 \mathrm{a}$, $16 \mathrm{c}$ 10a, 11b, $16 \mathrm{~cd}$,
- For the overweight category, associations were generally positive but nonsignificant $[\mathrm{OR}=1.14(0.73,1.77)]$ in the Q4 (vs. Q1) of BPA concentrations.

- A 2.71-fold increase in urinary BPA concentration was associated with increased $\mathrm{BMI}$ and $\mathrm{WC}[\beta=0.33(0.10,0.57)]$ and $[\beta=1.00(0.34,1.65)]$, respectively.

30-49 y $\quad 30-49$ y $1,7,8,14 a$ - Urinary BPA levels were associated with BMl $[\beta=0.04(0.01,0.06)]$ and WC $[\beta=0.02(0.01,0.03)]$ before the adjustment.

- $\quad$ BPA levels were also associated with BMI and WC $[\beta=0.03(0.01,0.06)$ and $\beta=0.02(0.01,0.03)$, respectively] even after potential covariate adjustment.

$1,3 \mathrm{~b}, 4 \mathrm{~b}$, - Urinary BPA concentration was associated with percentage of trunk fat in girls $[\beta=2.85(0.92,4.78)$ in $Q 2(1.50-3.16 \mathrm{ng} / \mathrm{ml}),[\beta=2.57(0.28,4.85)]$ in Q3 $(3.17-$ $6.05 \mathrm{ng} / \mathrm{ml})$ and $[\beta=2.79(0.44,5.14)]$ in Q4 $(\geq 6.06 \mathrm{ng} / \mathrm{ml})$, compared with Q1 (0.30-1.49 ng/ml).

- $\quad$ BPA levels in Q4 were associated with elevated LBMI z-score in boys $(p<0.05)$, and with elevated FMl z-scores in girls $(p<0.05)$.

- $\quad F M l z-s c o r e s$ were increased in the $Q 2[\beta=0.29(0.06,0.52)], Q 3[\beta=0.30(0.02$, $0.57)]$, and $Q 4[\beta=0.29(0.04,0.55)]$ of urinary BPA concentrations in overall participants.

$\geq 20$ y $1,2,3,4 b$, - The OR for GO comparing the Q4 $(>2.6,>1.00$ and $1.00 \mathrm{ng} / \mathrm{ml})$ with Q1 $(<0.6$, 6b, 7, 9b, $\quad<0.14$ and $<0.2 \mathrm{ng} / \mathrm{ml})$ for BPA, BPF and BPS were [1.78 $(1.10,2.89)],[1.02$

10a, 16a $\quad(0.70,1.47)]$, and $[1.22(0.81,1.83)]$, respectively. The corresponding odds for AO for BPA, BPF and BPS were [1.55 (1.04, 2.32)], [1.05 $(0.68,1.63)]$ and $[1.16$ $(0.72,1.88)]$, respectively.

1,10a - Positive associations were found between 2,5-DP and BMI, WC and \%BF Enterolactone was inversely associated with changes in BMI, WC, and \%BF fat in different ages.

- $\quad$ Differences in adiposity measurements were observed between tertiles of 2,5DP (T2 vs T1 and T3 vs T1) beginning at age 8-9 y, which consistently increased through age $13 \mathrm{y}$.

- Triclosan was positively associated with all adiposity measures only among overweight girls.

- $\quad$ BPA was inversely associated with \%BF.

$\geq 44$ y $1,2,3,5 \mathrm{c}, \quad$ - A 10-fold increase in BPA concentrations was positively associated with 2.30

$7,8,14 \mathrm{~b}, \quad$ folds of risk of $\mathrm{AO}$ incidence [OR=2.30 (1.39, 3.78)]. Compared with the T1 $(0.15-0.48 \mathrm{ng} / \mathrm{ml})$ of urinary BPA concentration, T2 $(0.71-1.00 \mathrm{ng} / \mathrm{ml})$ and T3 $(1.51-2.95 \mathrm{ng} / \mathrm{ml})$ were associated with a higher risk of $\mathrm{AO}$ incidence [OR=1.79 $(1.08,2.97)$ and $\mathrm{OR}=1.83(1.09,3.08)$, respectively].

- A 10-fold increase in BPA concentration was associated with $1.17 \mathrm{~cm}$ increment in WC (SE=0.46, $p=0.01)$.

- $\quad$ BPA positively associated with the AO incidence in women but not in men.

- Prenatal BPA exposure was not associated with obesity indices.

$1 \mathrm{ab}, 2 \mathrm{a}, \quad$ - Prenatal BPA expo

5a, 3c - In girls 4 y of age, increased BPA exposure was associated with sum of ST $[\beta=3.47(0.05,6.40)]$.

- Child sex modified the relationships between specific gravity-corrected and Intransformed urinary BPA levels and BMIZ $[\beta=0.05(-0.16,0.25)]$ and sum of ST $[\beta=0.97(-1.01,2.94)]$. These associations might depend on pubertal transitions.

$1 \mathrm{ab}, 2 \mathrm{a}$, - Before adjustment, maternal urinary concentrations of 2,5-DP were associated 3a, 5ade, $\quad$ with greater \%FM $[\beta=1.24(0.08,2.40)]$ and BeP-3 were associated with lower $6 \mathrm{a}, 7 \mathrm{~b}, 9 \mathrm{~b}, \quad \% \mathrm{FM}[\beta=-1.13(-2.24,0.00)]$ among children.

10a, 15, - BeP-3 concentrations were inversely associated with \%FM in girls $[\beta=-1.51$ $(-3.06,0.01)]$ but not boys $[\beta=-0.20(-1.69,1.26)]$.

- After adjustment, null associations were observed for all phenol markers with \% FM.

2a, 5efg, - Prenatal In-transformed BPA concentrations were associated with FMl [ $\beta=0.31$ $(0.01,0.60)], \% B F[\beta=0.79(0.03,1.55)]$ and $W C[\beta=1.29(0.29,2.30)]$ but null with $\mathrm{BMIZ}$ at $7 \mathrm{y}$.

- In girls, prenatal urinary BPA concentrations were associated with FMl $[\beta=0.48$ (0.50-0.91)] but not in boys at $7 \mathrm{y}$.

- Child urinary BPA concentrations (3y, 5 y) were not associated with obesity indices. 
TABLE 1 | Continued

\begin{tabular}{|c|c|c|c|c|c|c|}
\hline \multirow[t]{2}{*}{ Ref. } & \multirow{2}{*}{$\begin{array}{l}\text { Study type } \\
\text { (country), } \\
\text { Subjects (n) }\end{array}$} & \multicolumn{2}{|c|}{ Exposure } & \multirow{2}{*}{$\begin{array}{l}\text { Outcome } \\
\text { ass. time }\end{array}$} & \multirow[t]{2}{*}{ Covariates } & \multirow[t]{2}{*}{ Key findings } \\
\hline & & Marker & $\begin{array}{l}\text { Biomonitoring } \\
\text { time }\end{array}$ & & & \\
\hline (73) & $\begin{array}{l}\text { Birth cohort } \\
\text { (Greece), } \\
\text { Mother-child } \\
(500)\end{array}$ & BPA & $1^{\mathrm{st}} \mathrm{T}_{\mathrm{r}}, 2.5 \mathrm{y}, 4 \mathrm{y}$ & $2.5 \mathrm{y}, 4 \mathrm{y}$ & $\begin{array}{l}1 \mathrm{~b}, 2 \mathrm{a}, 3 \mathrm{a} \\
5 \mathrm{ag}, 6 \mathrm{a}, 15\end{array}$ & $\begin{array}{l}\text { BPA concentrations at } 4 \text { y were associated with increased child } B M I Z[\beta=0.2 \\
(0.01,0.4)] \text {, WC }[\beta=1.2(0.1,2.2)] \text { and sum of } S T[\beta=3.7(0.7,6.7)] \text {, and a higher } \\
\text { prevalence of obesity }[R R=2.9(0.8,10.5)] \text { at age } 4 \text {. } \\
\text { - } \log _{10} \text {-transformed creatinine-adjusted BPA concentrations during pregnancy } \\
\text { and early childhood }(2.5 \mathrm{y} \text { and } 4 \mathrm{y}) \text { were associated with obesity }[\mathrm{RR}=0.1 \\
(0.003,5.4) \text { for maternal; } R R=0.3(0.01,6.4) \text { and } R R=2.9(0.8,10.5) \text { for } \\
\text { childhood BPA, respectively]. }\end{array}$ \\
\hline (74) & $\begin{array}{l}\text { Panel-cohort } \\
\text { (Korea), Elder } \\
\text { people (558) }\end{array}$ & BPA & $60-87$ y & $60-87$ y & $\begin{array}{c}1,2,6 \mathrm{bg} \\
7 \mathrm{c}, 8,9 \mathrm{a} \\
14 \mathrm{bc}\end{array}$ & $\begin{array}{l}\text { - Per IQR increase }(0.96 \mu \mathrm{g} / \mathrm{g} \text { of creatinine) in log-transformed BPA was } \\
\text { associated with overweight }[\mathrm{OR}=1.17(1.04,1.32)] \text {. A significant association was } \\
\text { found in women }[\mathrm{OR}=1.25(1.09,1.45)] \text {, but not in men }[\mathrm{OR}=0.97(0.77,1.22)] \text {. } \\
\text { ORs of overweight increased with quartiles of BPA (Q1 }=0.38, \mathrm{Q} 2=0.39-0.75 \text {, } \\
\mathrm{Q} 3=0.76-1.41 \text { and } \mathrm{Q} 4=\geq 1.42 \mu \mathrm{g} / \mathrm{g} \text { of creatinine) in women }[\mathrm{Q} 2 \mathrm{OR}=1.54 \\
(1.02,2.32), \mathrm{Q} 3 \mathrm{OR}=1.70(1.10,2.62) \text {, and Q4 } \mathrm{OR}=1.81(1.13,2.92)] \text {. }\end{array}$ \\
\hline (75) & $\begin{array}{l}\text { Cross- } \\
\text { sectional } \\
\text { (Cyprus), } \\
\text { Adults } \\
(223)\end{array}$ & $\begin{array}{l}\text { BPA, mono- } \\
\text { chloro BPA }\end{array}$ & $\geq 18 y$ & $\geq 18 y$ & $1,2,3,14 d$ & $\begin{array}{l}\text { - A significant correlation was observed between creatinine-adjusted urinary } \\
\text { mono-chloro }(\mathrm{mCl}) \mathrm{BPA} \text { and } \mathrm{BMI}\left(\mathrm{r}_{\mathrm{S}}=0.18, p=0.0087\right) \text {. } \\
\text { Observed an increase prevalence in above normal BMI participants with } \\
\text { increasing tertile of creatinine-adjusted urinary In-transformed mCIBPA ( } p=0.056) \\
\text { but not for BPA }(p=0.254) \text {. } \\
\text { - An increase in the OR for above normal BMl was observed for the T3 of } \\
\text { creatinine-adjusted urinary BPA }[>2697 \mathrm{ng} / \mathrm{g}, \mathrm{OR}=1.17(0.57,2.43)] \text { and } \\
\text { mCIBPA }[>108 \mathrm{ng} / \mathrm{g}, \mathrm{OR}=1.14(0.50,2.59)] \text { compared with } \mathrm{T} 1 \text {. }\end{array}$ \\
\hline (76) & $\begin{array}{l}\text { Cross- } \\
\text { sectional } \\
\text { (Italy), Elder } \\
\text { male (76) }\end{array}$ & BPA & 53.5 y (mean) & 53.5 y & NA & $\begin{array}{l}\text { - Significantly higher BPA levels were observed in the subjects with visceral } \\
\text { obesity }(\mathrm{WC}>102 \mathrm{~cm}) \text { compared to the subjects with } \mathrm{WC}<102 \mathrm{~cm} \text {. }\end{array}$ \\
\hline$(77)$ & $\begin{array}{l}\text { Cross- } \\
\text { sectional } \\
\text { (Korea), } \\
\text { Adults (1030) }\end{array}$ & BPA & 44.3 y (mean) & 44.3 y & $\begin{array}{l}1,2,3,4 a \\
7,8,16 a\end{array}$ & $\begin{array}{l}\text { - WC was higher among subjects with a urinary BPA concentration in the Q4 } \\
\text { - }>2.594 \mu \mathrm{g} / \mathrm{ml}) \text { relative to those in the } \mathrm{Q} 1(<0.853 \mu \mathrm{g} / \mathrm{ml})(p=0.0071) \text {. } \\
\text { Positive associations were found between urinary BPA concentrations and BMI } \\
(\beta=0.1866 ; p=0.0128), \mathrm{WC}(\beta=0.0564 ; p=0.0533) \text {, and } \% \mathrm{BF}(\beta=0.1091 ; \\
p=0.0389) \text {. } \\
\text { Subjects at Q4 were more likely to be obese compared to those at Q1 } \\
{[\mathrm{OR}=1.94(1.31,2.86)] \text {. }}\end{array}$ \\
\hline$(78)$ & $\begin{array}{l}\text { Birth cohort } \\
\text { (USA), } \\
\text { Mother-child } \\
(297)\end{array}$ & BPA & $\begin{array}{c}2^{\text {nd }}-3^{\text {rd }} T_{r}, 1-2 \\
y\end{array}$ & $2-5 y$ & $\begin{array}{l}1 \mathrm{~b}, 3 \mathrm{a} \\
4 \mathrm{ac}, 5 \mathrm{c} \\
6 \mathrm{~h}, 7 \mathrm{c} \\
10 \mathrm{a}, 11 \mathrm{a} \\
12,14 \mathrm{e}\end{array}$ & $\begin{array}{l}\text { - A 10-fold increase in prenatal and early-childhood BPA concentrations was } \\
\text { associated with a reduction in child BMI }[\beta=-0.1(-0.5,0.3) \text { and } \beta=-0.2(-0.6 \text {, } \\
\text { 0.1), respectively]. } \\
\text { Children in the early-childhood at T3 of BPA }(20-314 \mu \mathrm{g} / \mathrm{g} \text { of creatinine) had } \\
\text { lower BMl at } 2 \mathrm{y} \text { [difference=-0.3 }(-0.6,0.0)] \text { and larger increases in their BMl } \\
\text { slope from } 2 \text { through } 5 \mathrm{y} \text { [BMl increase per year=0.12 }(0.07,0.18)] \text { than children } \\
\text { in the T1 }(2.1-11 \mu \mathrm{g} / \mathrm{g} \text { of creatinine) }[\mathrm{BMI} \text { increase per year=0.07 }(0.01,0.13)] \text {. }\end{array}$ \\
\hline (79) & $\begin{array}{l}\text { Birth cohort } \\
\text { (USA), } \\
\text { Mother-child } \\
(311)\end{array}$ & BPA & $\begin{array}{l}1^{\text {st }}-2^{\text {nd }} T_{r}, 5 y \\
9 y\end{array}$ & $5 y, 9 y$ & $\begin{array}{l}6,8,9,10 \\
43,44,45 \\
3 a, 4 a, 5 a \\
7 b, 6 i j, 13 b\end{array}$ & $\begin{array}{l}\text { - Prenatal BPA concentrations was associated with decreased BMIZ }[\beta=-0.47 \\
(-0.87,-0.07)] \text { and } \% \mathrm{BF}[\beta=-4.36(-8.37,-0.34)] \text { and decreased odds of } \\
\text { overweight/obesity }[\mathrm{OR}=0.37(0.16,0.91)] \text { in } \mathrm{T} 3(1.7-27.0 \mu \mathrm{g} / \mathrm{l}) \mathrm{vs} \mathrm{T} 1(<\mathrm{LOD}-1.0 \\
\mu \mathrm{g} / \mathrm{l}) \text { among girls. } \\
\text { - Urinary BPA concentrations at } 5 \mathrm{y} \text { of age were not associated with obesity } \\
\text { indices at } 5 \text { or } 9 \mathrm{y} \text {. } \\
\text { BPA concentrations at } 9 \mathrm{y} \text { were positively associated with BMIZ }[\beta=0.55(0.15 \text {, } \\
\text { 0.95)], WC }[\beta=5.89(1.19,10.59)] \text {, FM }[\beta=4.62(0.26,8.98)] \text {, and overweight/ } \\
\text { obesity }[\beta=4.20(1.60,11.02)] \text { at } 9 \mathrm{y} \text { in boys and girls. }\end{array}$ \\
\hline (80) & $\begin{array}{l}\text { Birth cohort } \\
\text { (Spain), } \\
\text { Mother-child } \\
(402)\end{array}$ & BPA & $1^{\text {st }}, 3 r d T_{r}$ & $\begin{array}{c}6 \mathrm{~m} \\
14 \mathrm{~m}, 4 \mathrm{y}\end{array}$ & $\begin{array}{c}1 \mathrm{ab}, 2 \mathrm{a}, \\
3 \mathrm{a}, 5 \mathrm{a}, 7 \mathrm{~b} \\
10 \mathrm{~b}, 11 \mathrm{ac}\end{array}$ & $\begin{array}{l}\text { - A 10-fold increase in creatinine adjusted BPA concentration was associated with } \\
\text { increased WC } z \text {-score }[\beta=0.28(0.01,0.57)] \text {, BMIZ }[\beta=0.28(-0.06,0.63)] \text {, and } \\
\text { BMIZ } \geq 85 \text { th percentile }[R R=1.38(0.72,2.67)] \text { at } 4 \mathrm{y} \text {. } \\
\text { BPA was not associated with obesity-related outcomes at earlier ages (at } 6 \mathrm{~m} \\
\text { and } 14 \mathrm{~m} \text { of age). }\end{array}$ \\
\hline$(81)$ & $\begin{array}{l}\text { Cross- } \\
\text { sectional } \\
\text { (China), } \\
\text { School } \\
\text { children } \\
(1326)\end{array}$ & BPA & $9-12 y, \geq 12 y$ & $\begin{array}{c}9-12 y, \geq \\
12 y\end{array}$ & $\begin{array}{l}1,2,3 a \\
5 h, 6 e k \\
9 e f, 13 c \\
14 a, 16 a\end{array}$ & $\begin{array}{l}\text { - A higher urine BPA level }(\geq 2 \mu \mathrm{g} / \mathrm{l}) \text { was associated with more than } 2 \text {-fold } \\
\text { increased risk of overweight/obese (weight } \geq 90 \text { th percentile) among girls aged } \\
9-12 \text { y }[\mathrm{OR}=2.32(1.15,4.65)] \text {. } \\
\text { Similar associations were also found for hip circumference }[\mathrm{OR}=2.88(1.12 \text {, } \\
\text { 7.45)], WC }[\mathrm{OR}=2.60(0.98,6.91)] \text {, weight to height ratio }[\mathrm{OR}=2.38(0.92,6.16)] \text {, } \\
\text { ST }[\mathrm{OR}=1.86(0.73,4.71)] \text { and } \mathrm{BMI}[\mathrm{OR}=1.47(0.71,3.05)] \text {. }\end{array}$ \\
\hline
\end{tabular}


TABLE 1 | Continued

\begin{tabular}{|c|c|c|c|c|c|c|}
\hline \multirow[t]{2}{*}{ Ref. } & \multirow{2}{*}{$\begin{array}{l}\text { Study type } \\
\text { (country), } \\
\text { Subjects (n) }\end{array}$} & \multicolumn{2}{|c|}{ Exposure } & \multirow{2}{*}{$\begin{array}{l}\text { Outcome } \\
\text { ass. time }\end{array}$} & \multirow[t]{2}{*}{ Covariates } & \multirow[t]{2}{*}{ Key findings } \\
\hline & & Marker & $\begin{array}{l}\text { Biomonitoring } \\
\text { time }\end{array}$ & & & \\
\hline$(82)$ & $\begin{array}{l}\text { Cross- } \\
\text { sectional } \\
\text { (USA), } \\
\text { Children } \\
\text { (2664) }\end{array}$ & BPA & $6-18$ y & $6-18$ y & $\begin{array}{c}1,2,3,7 c \\
9 b, 10 a \\
16 a\end{array}$ & 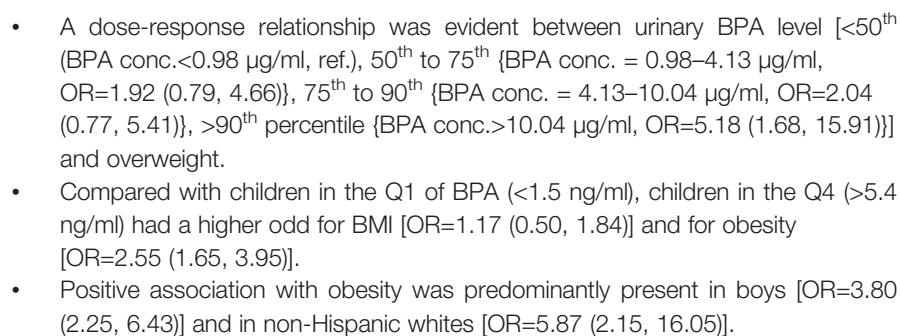 \\
\hline (83) & $\begin{array}{l}\text { Cross- } \\
\text { sectional } \\
\text { (USA), } \\
\text { Children and } \\
\text { adolescents } \\
(2838)\end{array}$ & BPA & $6-19 y$ & $6-19 y$ & $\begin{array}{l}1,2,3 a \\
4 b, 6 b, 7 c \\
9 c, 10 a \\
16 a\end{array}$ & $\begin{array}{l}\text { - Urinary BPA showed dose-dependent associations with BMIZ. The odds of } \\
\text { obesity were increased in the Q2 [OR=2.22 }(1.53,3.23)] \text {, Q3 }[\mathrm{OR}=2.09(1.48 \text {, } \\
\text { 2.95)], and Q4 [OR=2.53 }(1.72,3.74)] \text { of urinary BPA concentration. } \\
\text { Children in the Q1 BPA }(<1.5 \mathrm{ng} / \mathrm{ml}) \text { had a lower prevalence of obesity }[10.3 \% \\
(7.5,13.1)] \text { than those in } \mathrm{Q} 2(1.5-2.7 \mathrm{ng} / \mathrm{ml})[20.1 \%(14.5,25.6)], \mathrm{Q} 3(2.8-5.5 \\
\mathrm{ng} / \mathrm{ml})[19.0 \%(13.7,24.2)] \text {, and } \mathrm{Q} 4(\geq 5.6 \mathrm{ng} / \mathrm{ml})[22.3 \%(16.6,27.9)] \text {. } \\
\text { Race/ethnicity-urinary BPA quartile interaction with obesity as the outcome } \\
\text { showed significant interactions for only non-Hispanic white participants [Q2 } \\
\text { OR=3.10 (1.33, 7.21); Q3 OR=3.33 }(1.48,7.49) ; \mathrm{Q} \text { OR=4.08 }(1.66,10.0)] \text {. }\end{array}$ \\
\hline (84) & $\begin{array}{l}\text { Cross- } \\
\text { sectional } \\
\text { (China), Adults } \\
\text { (3390) }\end{array}$ & BPA & $\geq 40 y$ & $\geq 40 y$ & $\begin{array}{c}1,2,3,7 \\
8,14 \mathrm{cfg} \\
16 \mathrm{a}\end{array}$ & $\begin{array}{l}\text { - Compared with the participants in the Q1, those in the Q4 of urinary BPA had } \\
\text { significantly higher BMl }(p<0.001) \text { and } \mathrm{WC}(p<0.001) \text {. } \\
\text { Observed highest prevalence of GO }[\mathrm{OR}=1.50(1.15,1.97)] \text { and } \mathrm{AO}[\mathrm{OR}=1.28 \\
(1.03,1.60)] \text { in the Q4 of BPA }(>1.43 \mathrm{ng} / \mathrm{ml}) \text { in compared with Q1 }(\leq 0.47 \mathrm{ng} / \mathrm{ml}) \text {, } \\
\text { Q2 }(0.48-0.81 \mathrm{ng} / \mathrm{ml}) \text { and Q3 }(0.82-1.43 \mathrm{ng} / \mathrm{ml}) \text {. }\end{array}$ \\
\hline (85) & $\begin{array}{l}\text { Cross- } \\
\text { sectional } \\
\text { (China), } \\
\text { Children (259) }\end{array}$ & BPA & $8-15$ y & $8-15$ y & $1,2,16 d$ & $\begin{array}{l}\text { - Log-transformed urinary BPA concentrations were significantly associated with } \\
\text { increasing BMI }[\beta=0.017(0.002,0.032)] \text { in all subjects. }\end{array}$ \\
\hline (86) & $\begin{array}{l}\text { Cross- } \\
\text { sectional } \\
\text { (USA), Adults } \\
\text { (3967) }\end{array}$ & BPA & $\geq 20 y$ & $\geq 20 y$ & $\begin{array}{c}\text { 1, 2, 3, 7 } \\
8,9 \mathrm{~b}, 10 \mathrm{a} \\
14 \mathrm{bhi}\end{array}$ & $\begin{array}{l}\text { Positive association was found between increasing levels of urinary BPA, and } \\
\text { both GO and AO. Compared with Q1 }(<1.10 \mathrm{ng} / \mathrm{ml}), \mathrm{Q} 4(>4.20 \mathrm{ng} / \mathrm{ml}) \text { had } \\
\text { higher odds for GO [OR=1.69 }(1.30,2.20) \text { and } \mathrm{AO}[\mathrm{OR}=1.59(1.21,2.09)] \text { in } \\
\text { whole population. } \\
\text { Similar associations were also found after stratification in men, women, non- } \\
\text { Hispanic white, non-Hispanic blacks and Mexican Americans and others (p } \\
<0.05) \text {. }\end{array}$ \\
\hline$(41)$ & $\begin{array}{l}\text { Cross- } \\
\text { sectional } \\
\text { (USA), Adults } \\
(2747)\end{array}$ & BPA & $18-74$ y & $18-74$ y & $\begin{array}{l}1,2,3,7 \\
10 a, 16 a\end{array}$ & $\begin{array}{l}\text { - Compared to participants in the Q1 of BPA }(\leq 1.1 \mathrm{ng} / \mathrm{ml}) \text {, participants in the Q4 } \\
\text { were obese [\{Q2 }(1.2-2.3 \mathrm{ng} / \mathrm{ml}), \mathrm{OR}=1.85(1.22,2.79)\} ;\{\mathrm{Q} 3(2.4-4.6 \mathrm{ng} / \mathrm{ml}), \\
\text { OR=1.60 }(1.05,2.44)\} ;\{\mathrm{Q} 4(\geq 4.7 \mathrm{ng} / \mathrm{ml}) \text {, OR=1.76 }(1.06,2.94)\}] . \\
\text { Higher BPA concentration was also associated with } \mathrm{AO}[\mathrm{Q} 2 \mathrm{OR}=1.62(1.11 \text {, } \\
\text { 2.36); Q3 OR=1.39 (1.02, 1.90); Q4 OR=1.58 (1.03, 2.42)]. }\end{array}$ \\
\hline
\end{tabular}

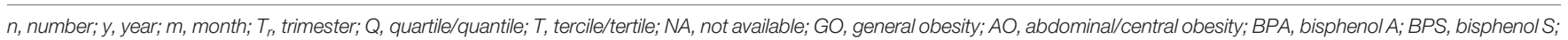

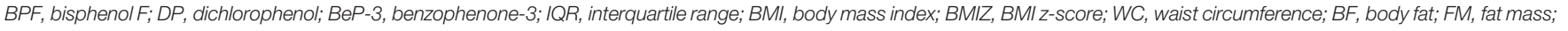
FMI, fat mass index; LBMI, lean body mass index; ST, skinfold thickness; OR, odds ratio; RR, relative risk; GW, weeks of gestation; $\Sigma D E H P$, sum of di-2-ethylhexyl phthalate.

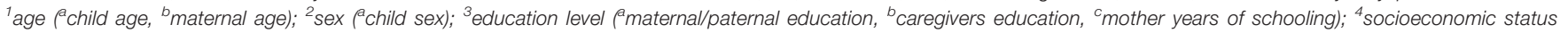

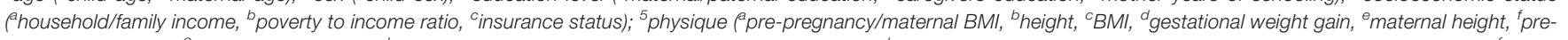

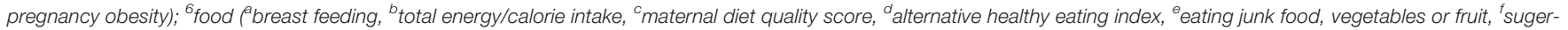

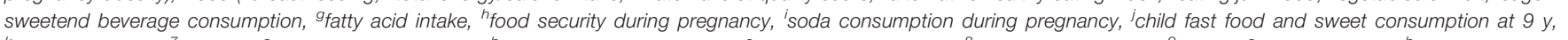

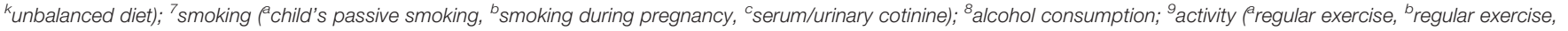

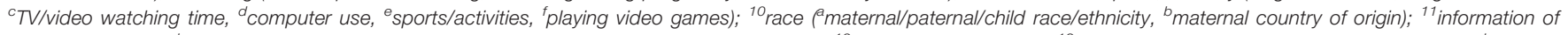

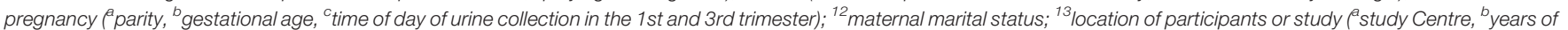

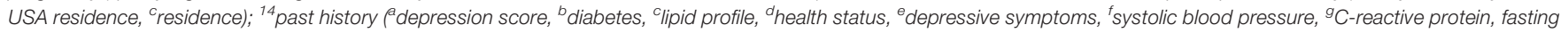

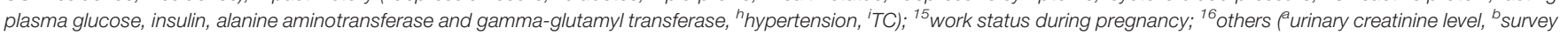
year, ${ }^{c}$ maternal/prenatal sum of DEHP, ' urinary specific gravity).

[All outcome ranges within the first bracket indicate the 95\% Cl].

in infants and toddlers $(61,73,80)$. Similar associations were also found between maternal BPA exposure levels and obesity measures in preschoolers and school-aged children. These associations were sex-specific $(8,50,61,70-73,78,80)$. Only one study reported negative associations between prenatal BPA exposure and BMI $\mathrm{Z}$-score and \%BF (79). Toddler and preschooler exposure levels of BPA reported null or positive associations with overweight or obesity indices in toddlers, preschoolers, and school-aged children (8, 70, 72, 73, 78, 79). Associations were mostly null in children 5 to 9 years of age ( 72 , 79). Urinary BPA concentrations among school-aged children showed inconsistent relationships with one or more obesity 
indices $(8,63,68,79,81)$. However, several studies recruited children with ages ranging from 6 to 19 years and investigated the associations of urinary BPA, BPS, and BPF exposure levels with overweight and obesity indices. All these studies found positive associations with one or more anthropometric parameters of obesity $(7,34,62,66,82,83,85)$. Adult exposure levels of BPA, BPS, and BPF were also positively associated with at least one anthropometric index of obesity in adults and elderly individuals $(2,41,48,64,65,67,69,75-77,84,86)$ with the exception of inconsistent associations in one study (63). One panel study (cohort) investigated the association between urinary BPA concentrations and overweight. The authors reported a positive association in the case of overall and female study participants, but not in male participants (74). Some other studies also observed a sex-stratified relationship between prenatal bisphenol exposure and overweight and obesity indices $(8,61,72,79)$. A few studies reported sex-dependent associations between childhood bisphenol exposure levels and obesity or adiposity measures $(7,66,81)$. Race- or ethnicityspecific associations of urinary BPA concentrations with obesity indices were also reported, with a significant association of BPA levels only in non-Hispanic white subjects (83). Pubertal status was reported as a confounder of the associations between BPA concentrations and BMI, WC, and ST, especially in girls $(70,79)$. Maternal exposure levels of 2, 5-dichlorophenol, benzophenone3 , and triclosan showed null associations with \%FM in children aged 4-9 years (71). In contrast, one study reported positive associations between urinary 2, 5-dichlorophenol levels in children aged 6-8 years and $\mathrm{BMI}, \mathrm{WC}$, and $\% \mathrm{BF}$ in later childhood, which consistently increased up to 13 years of age (68).

BPA levels in urine varied among the studies and ranged from non-detectable to $>2594 \mathrm{ng} / \mathrm{ml}$ (Table 1). Children and adolescents (6-19 years) with urinary BPA, BPS, and BPF concentrations of $\geq 2, \geq 1.30$, and $\geq 0.2 \mathrm{ng} / \mathrm{ml}$, are susceptible to developing overweight or obesity $(7,34,62,81)$. In adults, BPA, BPS, and BPF showed obesogenic effects at concentrations $\geq 0.71, \geq 1$, and $1 \mathrm{ng} / \mathrm{ml}$, respectively $(41,64,67,69,77,86)$. In addition, BPA concentrations $\geq 0.39 \mathrm{ng} / \mathrm{ml}$ may be responsible for subsequent development of overweight or obesity in elderly people (74).

\section{Environmental Phthalates and Obesity}

A total of 32 studies (11 birth cohort, 19 cross-sectional, and 2 case-control studies) explored the association of both prenatal and postnatal urinary exposure levels of phthalate metabolites with overweight and obesity measures in human populations of different ages (Table 2, and Matrix Tables 2, 3). In the birth cohort studies, urine samples were collected from both the pregnant mother and their children aged 1-14 years. The study subjects ranged from 128 to 1128 mother-child pairs in the birth cohorts. Among the 19 cross-sectional studies, 11 involved children and adolescents, 8 involved only adults and elderly people (male and/or female) of different ages. Almost all the studies determined phthalate metabolites in the spot urine of the study participants.
Associations between maternal $1^{\text {st }}$ trimester DEHP exposure levels and obesity measures in preschoolers, school-aged children, and adolescents were inconsistent (50, 70, 87, 93). Similarly, the individual or sum of maternal $2^{\text {nd }}$ trimester urinary DEHP metabolites showed both positive and null associations with different obesity indices in preschoolers, school-aged children, and adolescents (50, 87, 95, 96). However, negative or null associations were found between the $2^{\text {nd }}$ and $3^{\text {rd }}$ trimester DEHP exposure levels and anthropometric obesity indices in infants, preschoolers, school-aged children, and adolescents (50, 87, 98-101). Infant (1 year) exposure to DEHP was negatively associated with obesity indices at 8 years of age. In contrast, preschoolers exposed to DEHP (4 and 5 years) were negatively or positively associated $(93,96)$. Associations of DEHP exposure levels at 6-19 years of age (individual metabolite levels or sum of levels) with overweight or obesity indices in school-aged children and adolescents were very inconsistent (89-92, 94, 96, 102, 105-111). Most of the studies that recruited adults and elderly people reported positive or null associations between one or more DEHP metabolites or the sum of DEHP and different overweight and obesity indices in overall adult and elderly populations or after sex stratification $(2,48,49$, $65,88,97,104,106,111,112)$.

Similar inconsistent associations were also found among nonDEHP metabolites [mono-butyl phthalate (MBP), mono-ethyl phthalate (MEP), mono-methyl phthalate (MMP), mono-benzyl phthalate (MBzP), mono-isobutyl phthalate (MiBP), mono(carboxylnonyl) phthalate (MCNP), mono-isononyl phthalate (MINP), and others], and obesity indices at different stages of life. First to $3^{\text {rd }}$-trimester maternal urinary concentrations of non-DEHP metabolites (except MCPP) displayed null or negative associations with anthropometric parameters of obesity in preschoolers, school-aged children, and adolescents $(50,70,93,98,99,101,103)$. In contrast, one study found positive associations between maternal urinary concentrations of MEP, MBP, MBzP, and MiBP and obesity indices among all study participants (95). Another study also found positive associations after sex-stratified analysis in both males (MBzP) and females (MiBP and MBP) (87). Exposure levels of nonDEHP metabolites in toddlers and preschoolers showed null associations with their obesity measures $(96,101)$. However, one study described positive associations between MEP, MBP, and MBP, and obesity indices in girls, with negative associations in boys (93). Exposure levels of school-aged to adolescents to nonDEHP metabolites (MMP, MEP, MBP, MiBP, and MBzP) were mostly positively associated with one or more anthropometric indices in school-aged children or adolescents $(89,91,92,94,96$, $102,105-110)$. In contrast, after sex stratification, inconsistent associations were evident $(94,102,107,110)$. One study recruited subjects 6-80 years old and found inconsistent associations among non-DEHP metabolite concentrations at different exposures (6-11, 12-19, 20-59 and 60-80 y) and corresponding outcome assessment ages (111). Exposure levels of non-DEHP metabolites in adults and the elderly also showed null or positive associations with their overweight and obesity indices (2, 48, 49, $65,88,97,104,106,112)$. One study evaluated ethnicity- 
TABLE 2 | Associations of environmental phthalates with anthropometric overweight and obesity indices.

\begin{tabular}{|c|c|c|c|c|c|c|}
\hline \multirow[t]{2}{*}{ Ref. } & \multirow{2}{*}{$\begin{array}{l}\text { Study type } \\
\text { (country), } \\
\text { Subjects (n) }\end{array}$} & \multicolumn{2}{|c|}{ Exposure } & \multirow{2}{*}{$\begin{array}{l}\text { Outcome } \\
\text { ass. time }\end{array}$} & \multirow[t]{2}{*}{ Covariate } & \multirow[t]{2}{*}{ Key findings } \\
\hline & & Markers & $\begin{array}{c}\text { Biomonitoring } \\
\text { time }\end{array}$ & & & \\
\hline (49) & $\begin{array}{l}\text { Cross- } \\
\text { sectional } \\
\text { (China) Elder } \\
\text { men and } \\
\text { women (942) }\end{array}$ & $\begin{array}{l}\text { MBP, MEP, MMP, } \\
\text { DEHP (MEHP, MEHHP, } \\
\text { MEOHP), MBzP }\end{array}$ & $\geq 60 y$ & $\geq 60 y$ & $\begin{array}{l}1,2,4 a \\
7,8,9 a \\
13 a, 15\end{array}$ & 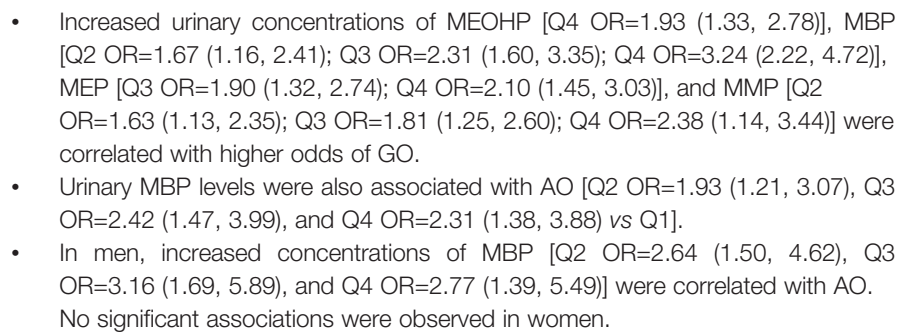 \\
\hline (2) & $\begin{array}{l}\text { Cross- } \\
\text { sectional } \\
\text { (Korea), } \\
\text { Adult (702) }\end{array}$ & $\begin{array}{l}\text { MiBP, MBP, MECPP } \\
\text { MEHHP, MEOHP, } \\
\text { MBzP }\end{array}$ & $40.1 \mathrm{y}$ & $\begin{array}{l}40.1 \mathrm{y} \\
\text { (mean) }\end{array}$ & $\begin{array}{c}1,2,7,8 \\
9 b\end{array}$ & $\begin{array}{l}\text { - Log transformed urinary phthalate metabolite concentrations were not } \\
\text { associated with } \mathrm{GO}\left[\sum \text { Phthalate metabolites, } \mathrm{OR}=0.93(0.68,1.28)\right] \text { and } \mathrm{AO} \\
{[\Sigma \text { Phthalate metabolites, OR=0.98 }(0.68,1.40)] \text {. }}\end{array}$ \\
\hline (50) & $\begin{array}{l}\text { Birth cohort } \\
\text { (Netherland), } \\
\text { Mother-child } \\
\text { (1128) }\end{array}$ & $\begin{array}{l}\text { MiBP, MBnP, MEP, } \\
\text { MMP, MBzP, MHxP, } \\
\text { MHPP, MCHP, MCPP } \\
\text { MEHHP, MEOHP, } \\
\text { MECPP, MCMHP, PA }\end{array}$ & $1^{\text {st }}-3^{r d} T_{r}$ & $10 y$ & $\begin{array}{l}1 \mathrm{ab}, 2 \mathrm{a} \\
3 \mathrm{a}, 5 \mathrm{a} \\
6 \mathrm{a}, 7,8 \\
10 \mathrm{a} 11 \mathrm{a}\end{array}$ & $\begin{array}{l}\text { - A 2.72-fold increase in PA concentrations in } 1^{\text {st }} T_{r} \text { of pregnancy were } \\
\text { associated with an increase in childhood BMI }[S D S=0.07(0.00,0.14)] \text {. } \\
\text { - Null associations were observed between other phthalate metabolites and BMl. }\end{array}$ \\
\hline$(87)$ & $\begin{array}{l}\text { Birth cohort } \\
\text { (Mexico), } \\
\text { Mother-child } \\
\text { (223) }\end{array}$ & $\begin{array}{l}\text { MBP, MiBP, MEP, } \\
\text { MCPP, MEHP, MEHHP, } \\
\text { MEOHP, MECPP, MBzP }\end{array}$ & $1^{\text {st }}-3^{r d} T_{r}, 8-14 y$ & $\begin{array}{c}8-14 y, 9- \\
17 y\end{array}$ & $\begin{array}{c}1 \mathrm{~b}, 3 \mathrm{a} \\
18 \mathrm{a}\end{array}$ & $\begin{array}{l}\text { - Natural log-transformed } 1^{\text {st }} T_{r} \text { MiBP concentrations were associated with } \\
\text { increased } S T[\beta=3.41(1.50,5.31)], B M I Z[\beta=0.28(0.12,0.45)] \text { and } \mathrm{WC}[\beta=2.33 \\
(0.86,3.8)] \text {, and MBP with only } \mathrm{BMIZ}[\beta=0.25(0.03,0.46)] \text {. Second } \mathrm{T}_{\mathrm{r}} \mathrm{MBzP} \\
\text { concentration was associated with decreased } \mathrm{ST}[\beta=-2.53(-4.78,-0.28)] \\
\text { among girls. } \\
\text { Maternal urinary } 2^{\text {nd }} \mathrm{T}_{r} \mathrm{MBzP} \text { concentration was also associated with BMIZ } \\
{[\beta=0.25(0.01,0.49)] \text { and } \mathrm{WC}[\beta=2.11(0.27,3.95)] \text { among boys. }}\end{array}$ \\
\hline (88) & $\begin{array}{l}\text { Cross- } \\
\text { sectional } \\
\text { (Korea), } \\
\text { Adults (4752) }\end{array}$ & $\begin{array}{l}\text { MBP, } \Sigma \text { DEHP (MEHHP, } \\
\text { MEOHP, MECPP), } \\
\text { MBzP }\end{array}$ & $\geq 19 y$ & $\geq 19 y$ & $\begin{array}{l}1,3,12 \\
4 a, 7,8 \\
9 b\end{array}$ & $\begin{array}{l}\text { - In women, urinary MEHHP and } \sum \mathrm{DEHP} \text { concentrations were associated with } \\
\text { obesity [Q4 vs Q1; OR=1.72 }(1.19,2.49) \text { and } \mathrm{OR}=1.52(1.04,2.21) \text {, } \\
\text { respectively]. } \\
\text { In men, urinary MBP concentration was found to be significantly associated with } \\
\text { obesity [Q4 vs Q1; OR=0.71 }(0.50,0.99)] \text {. } \\
\text { Women } \geq 50 \text { y showed positive associations between the MEHHP, MEOHP, } \\
\sum \mathrm{DEHP} \text {, and MBzP concentrations and obesity [Q4 vs Q1; OR=1.94 (1.28, } \\
2.94), \mathrm{OR}=1.88(1.21,2.94), \mathrm{OR}=2.04(1.31,3.18) \text {, and } \mathrm{Q} 3 \text { vs Q1; OR=1.45 } \\
(1.02,2.05)] \text {, respectively. }\end{array}$ \\
\hline$(48)$ & $\begin{array}{l}\text { Cross- } \\
\text { sectional } \\
\text { (USA), Adults } \\
\text { (1269) }\end{array}$ & MEP, MCOP, MECPP & $\geq 20 y$ & $\geq 20 y$ & $\begin{array}{c}1,2,3 \\
4 a, 6 b, 7 \\
9 a, 10 a \\
18 b\end{array}$ & $\begin{array}{l}\text { - MCOP concentrations were associated with } \mathrm{BMI}[\beta=0.36(0.06-0.66)] \text { and WC } \\
\text { - } \beta=0.98(0.28,1.69)] \text {. } \\
\text { MCOP and MECPP were associated with } \mathrm{GO}[\mathrm{OR}=1.80(1.22,2.65) \text { and } \\
\mathrm{OR}=1.62(1.04,2.51)] \text {, and } \mathrm{AO}[\mathrm{OR}=1.70(1.14,2.54) \text { and } \mathrm{OR}=1.59(1.01 \text {, } \\
2.51)] \text { at } \mathrm{Q} 4 \text { vs } \mathrm{Q} 1 \text {. } \\
\text { The weighted quantile sum index was associated with both } \mathrm{GO}[\mathrm{OR}=1.63(1.21 \text {, } \\
\text { 2.20)] and } \mathrm{AO}[\mathrm{OR}=1.66(1.18,2.34)] \text {. }\end{array}$ \\
\hline (89) & $\begin{array}{l}\text { Cross- } \\
\text { sectional } \\
\text { (Iran), } \\
\text { Children, } \\
\text { adolescent } \\
\text { (242) }\end{array}$ & $\begin{array}{l}\text { MBP, MEHP, MMP, } \\
\text { MEOHP, MEHHP, } \\
\text { MBZP, }\end{array}$ & $6-18 y$ & $6-18$ y & $\begin{array}{c}1,2,9 a \\
14 a b c, 17\end{array}$ & $\begin{array}{l}\text { - All metabolites had significant positive association with BMI, whereas only } \\
\text { MEOHP showed a significant association with WC after the adjustment. } \\
\text { Most of the phthalates were associated with obesity (T3 vs T1) [MBP: OR=1.26 } \\
\text { (0.54, 1.98)], [MBzP: OR=5.54 (4.79, 6.28)], [MMP: OR=4.26 }(3.56,4.96)] \text {, } \\
\text { [MEHP: OR=3.63 (2.95, 4.31)], and [MEHHP: OR=4.16 }(3.31,5.01)] \text {. }\end{array}$ \\
\hline (90) & $\begin{array}{l}\text { Case-control } \\
\text { (Korea), Girls } \\
(137)\end{array}$ & $\begin{array}{l}\text { MEHP, MEHHP, } \\
\text { MEOHP, MECPP }\end{array}$ & $6-13 y$ & $6-13 y$ & $1,5 b, 16 a$ & $\begin{array}{l}\text { - In pubertal girls, null associations were found between DEHP metabolites and } \\
\text { obesity indices. \%MEHHP among all DEHP metabolites was higher in the } \\
\text { overweight prepubertal girls than in the controls. } \\
\text { - The \%MEHHP was positively associated with the } \mathrm{BMI}[\beta=1.93(0.18,3.70)] \text {, WC } \\
\text { [ } \beta=0.67(0.15,1.19)] \text {, and \%BF }[\beta=0.60(0.03,1.18)] \text { in prepubertal girls. } \\
\text { The \%MEHHP of prepubertal girls in } \mathrm{Q} 3 \text { and } \mathrm{Q} 4 \text { was significantly higher OR for } \\
\text { AO than those in Q1 (OR=5.05 for } \mathrm{Q} 3 \text { and } \mathrm{OR}=7.30 \text { for } \mathrm{Q} 4) \text {. }\end{array}$ \\
\hline (91) & $\begin{array}{l}\text { Case-control } \\
\text { (China), Child } \\
(149)\end{array}$ & $\begin{array}{l}\text { MMP, MEP, MBP, } \\
\text { MEHP, MEOHP, } \\
\text { MEHHP }\end{array}$ & $10-15 y$ & $10-15 y$ & $\begin{array}{c}1,2,4 b \\
6 b, 9 a \\
16 b\end{array}$ & $\begin{array}{l}\text { - Compared with normal weight children, higher levels of MBP were detected in } \\
\text { urinary samples of children with overweight and obesity. } \\
\text { Positive association was found between urinary MBP concentration and } \\
\text { childhood overweight/obesity }[\mathrm{OR}=1.586(1.043,2.412)] \text {. }\end{array}$ \\
\hline (92) & $\begin{array}{l}\text { Cross- } \\
\text { sectional } \\
\text { (Iran), Child } \\
\text { (242) }\end{array}$ & $\begin{array}{l}\text { MBP, MEHP, MMP, } \\
\text { MEOHP, MEHHP, } \\
\text { MBZP }\end{array}$ & $6-18$ y & $6-18$ y & $1,2,18 \mathrm{c}$ & $\begin{array}{l}\text { - After adjustment, all metabolites showed a positive relationship with BMIZ } \\
(\beta=0.17 \text { for } \mathrm{MEOHP}, \beta=0.18 \text { for } \mathrm{MBz}, \beta=0.22 \text { for } \mathrm{MBP}, \beta=0.23 \text { for } \mathrm{MEHP} \text { and } \\
\beta=0.30 \text { for } \mathrm{MEHHP} ; \beta \leq 0.005) \text { and } \mathrm{WC}(\beta=0.14 \text { for } \mathrm{MMP}, \beta=0.19 \text { for } \mathrm{MEOHP} \text {, }\end{array}$ \\
\hline
\end{tabular}


TABLE 2 | Continued

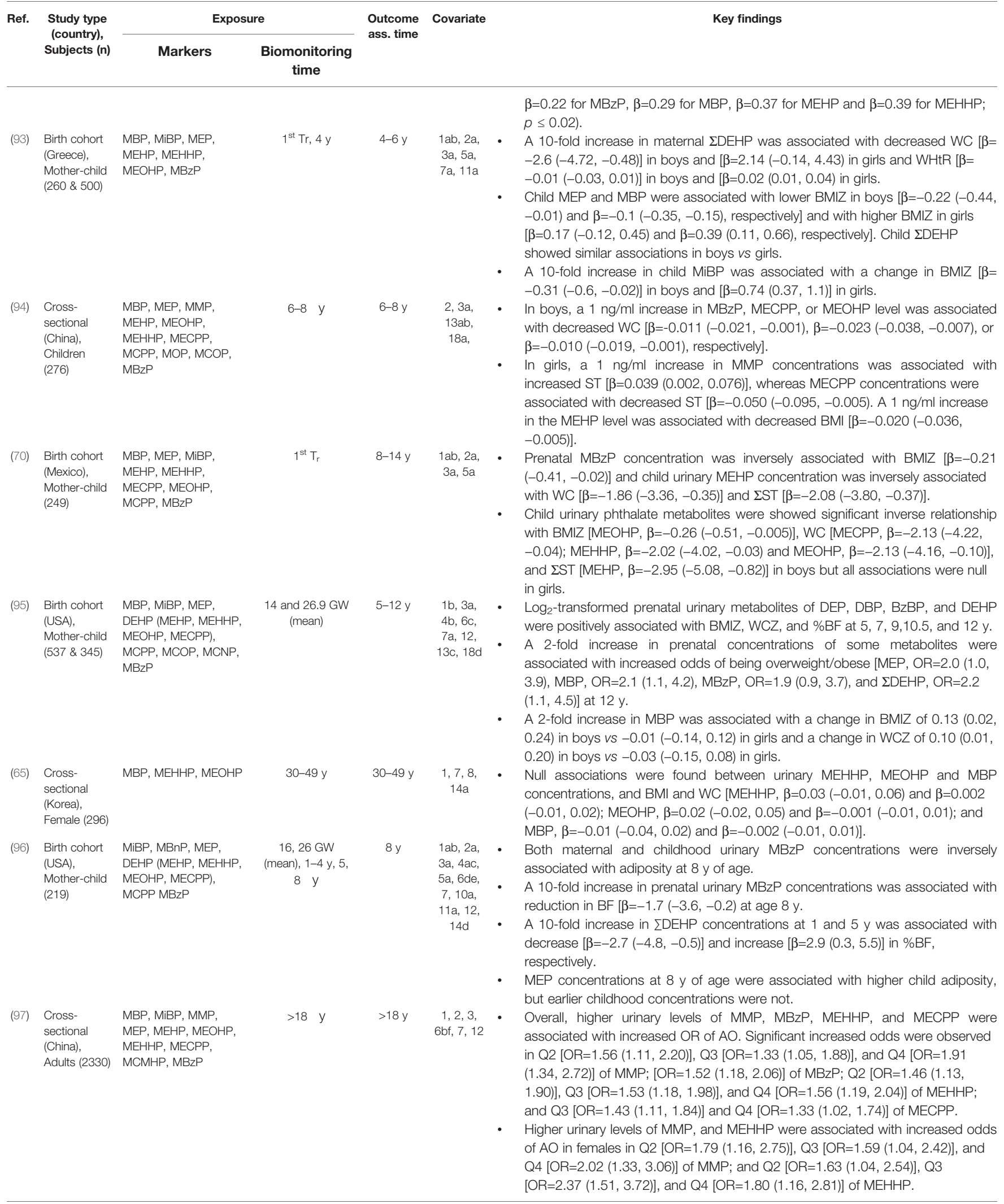


TABLE 2 | Continued

\begin{tabular}{|c|c|c|c|c|c|c|}
\hline \multirow[t]{2}{*}{ Ref. } & \multirow{2}{*}{$\begin{array}{l}\text { Study type } \\
\text { (country), } \\
\text { Subjects (n) }\end{array}$} & \multicolumn{2}{|c|}{ Exposure } & \multirow{2}{*}{$\begin{array}{l}\text { Outcome } \\
\text { ass. time }\end{array}$} & \multirow[t]{2}{*}{ Covariate } & \multirow[t]{2}{*}{ Key findings } \\
\hline & & Markers & $\begin{array}{c}\text { Biomonitoring } \\
\text { time }\end{array}$ & & & \\
\hline (98) & $\begin{array}{l}\text { Birth cohort } \\
\text { (USA), } \\
\text { Mother-child } \\
\text { (404 \& 180) }\end{array}$ & $\begin{array}{l}\text { DEP, MEP, MBP, MiBP, } \\
\text { ¿DEHP (MEHP, } \\
\text { MEHHP, MEOHP, } \\
\text { MECPP), MCPP MBzP, }\end{array}$ & $3^{\text {rd }} T_{r}$ & $4-9 y$ & $\begin{array}{l}1 \mathrm{ab}, 2 \mathrm{a} \\
3 \mathrm{a}, 5 \mathrm{abc} \\
6 \mathrm{~g}, 7 \mathrm{a} \\
9 \mathrm{a}, 10 \mathrm{a} \\
15 \mathrm{a}, 18 \mathrm{e}\end{array}$ & $\begin{array}{l}\text { - Maternal } \sum \mathrm{DEHP} \text { concentrations were associated with decreased \%FM }[\beta= \\
-3.06(-5.99,-0.09)] \text { among children in the T3 of } \Sigma \mathrm{DEHP} \text { concentrations than in } \\
\text { the children in T1. } \\
\text { Null associations were evident between } \Sigma \mathrm{DEHP} \text { metabolite concentrations and } \\
\text { BMIZ. }\end{array}$ \\
\hline (99) & $\begin{array}{l}\text { Birth cohort } \\
\text { (USA), } \\
\text { Mother-child } \\
(707)\end{array}$ & $\begin{array}{l}\text { MiBP, MBP, MEP, } \\
\text { ¿DEHP (MEHP, } \\
\text { MEHHP, MEOHP, } \\
\text { MECPP), MBzP, MCPP }\end{array}$ & $2^{\text {nd }}-3^{r d} T_{r}$ & $4-9 y$ & $\begin{array}{l}1 \mathrm{~b}, 2 \mathrm{a} \\
3 \mathrm{a}, 5 \mathrm{abc} \\
6 \mathrm{~g}, 7 \mathrm{a} \\
10 \mathrm{a}, 11 \mathrm{a} \\
13 \mathrm{~d}, 15 \mathrm{a} \\
18 \mathrm{be}\end{array}$ & $\begin{array}{l}\text { - Prenatal urinary MCPP concentrations were positively associated with } \\
\text { overweight/obese status in children }[\mathrm{OR}=2.1(1.2,4.0)] \text { but not with } \mathrm{BMIZ}[\beta= \\
-0.02(-0.15,0.11)] \text {. } \\
\text { - Maternal MEP and } \sum \mathrm{DEHP} \text { concentrations showed negative trend with } \mathrm{BMIZ} \\
\text { among girls }[\beta=-0.14(-0.28,0.00) \text { and } \beta=-0.12(-0.27,0.02) \text {, respectively]. } \\
\text { Urinary MCPP concentrations of Hispanic in compared with non-Hispanic } \\
\text { blacks showed higher odds [OR=3.7 }(1.6,9.1)] \text { of being overweight/obese, } \\
\text { although had null association with } \mathrm{BMIZ}[\beta=0.08(-0.11,0.27) \text {. }\end{array}$ \\
\hline (100) & $\begin{array}{l}\text { Birth cohort } \\
\text { (Korea) } \\
\text { Mother-child } \\
(128)\end{array}$ & $\begin{array}{l}\text { ¿DEHP (MEHHP, } \\
\text { MEOHP) }\end{array}$ & 38-40 GW & $3 \mathrm{~m}$ & $\begin{array}{c}1 b, 5 a \\
11 b c, 18 b\end{array}$ & $\begin{array}{l}\text { - } \quad \sum \text { DEHP exposure levels in newborns were associated with decrease of ponderal } \\
\text { index in boys }(\beta=-0.13, p=0.021) \text {. } \\
\text { - } \quad \sum \text { DEHP metabolites concentrations in newborns' urine were also associated } \\
\text { with increased BMIZ during the } 3 \mathrm{~m} \text { after birth [OR=4.35 }(1.20,15.72)] \text {. }\end{array}$ \\
\hline (101) & $\begin{array}{l}\text { Birth cohort } \\
\text { (USA), } \\
\text { Mother-child } \\
(424)\end{array}$ & $\begin{array}{l}\text { MiBP, MBnP, MEP, } \\
\text { MEHP, MEHHP, } \\
\text { MEOHP, MECPP, } \\
\text { MCPP, MBzP }\end{array}$ & $3^{\text {rd }} T_{r}, 3 y, 5 y$ & $5,7 y$ & $\begin{array}{c}1 \mathrm{a}, 4 \mathrm{~d} \\
5 \mathrm{a}, 10 \mathrm{a} \\
15 \mathrm{a}, 18 \mathrm{a}\end{array}$ & $\begin{array}{l}\text { - In PCA analysis, prenatal DEHP component scores were non significantly and } \\
\text { inversely associated with BMIZ at } 5 \text { and } 7 \mathrm{y} \text {. } \\
\text { In boys, higher maternal non-DEHP component scores were associated with } \\
\text { lower BMIZ }[\beta=-0.30(-0.50,-0.10)] \text {, \%BF }[\beta=-1.62(-2.91,-0.34)] \text {, FM index } \\
{[\beta=-0.50(-0.96,-0.04) \text { and smaller WC }[\beta=-2.02(-3.71,-0.32)] \text { at } 7 \mathrm{y} \text {. }}\end{array}$ \\
\hline (102) & $\begin{array}{l}\text { Cross- } \\
\text { sectional } \\
\text { (USA), Girls } \\
\text { (1239) }\end{array}$ & $\begin{array}{l}\text { LMWP (MEP, MBP, } \\
\text { MiBP, DBP, DiBP), } \\
\text { IDEHP (MEHP, } \\
\text { MEOHP, MECPP, } \\
\text { MEHHP), MBZP, MCPP }\end{array}$ & $6-8 \quad y$ & $7-13 y$ & $\begin{array}{l}1,1 \mathrm{c} \\
10 \mathrm{a} \\
18 \mathrm{fgh}\end{array}$ & 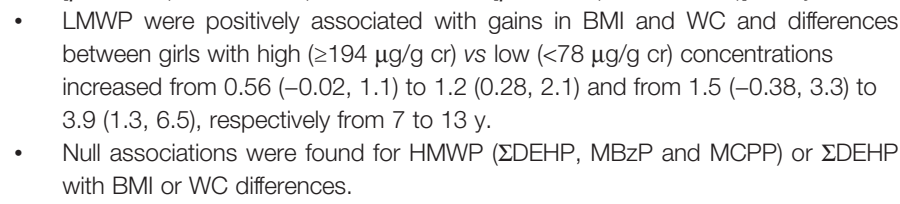 \\
\hline (103) & $\begin{array}{l}\text { Birth cohort } \\
\text { (Spain), } \\
\text { Mother-child } \\
(470)\end{array}$ & $\begin{array}{l}\text { MiBP, MBP, MEP, } \\
\text { MEHP, MEHHP, } \\
\text { MECPP, MEOHP, } \\
\text { MCMHP, MBZP, } \\
\text { 7OHMMEOP }\end{array}$ & $1^{\text {st }}, 3^{\text {rd }} T_{r}$ & $7 y$ & $\begin{array}{c}1 \mathrm{ab}, 2 \mathrm{a} \\
4 \mathrm{~b}, 5 \mathrm{acd} \\
6 \mathrm{~g}, 7 \mathrm{a} \\
10 \mathrm{~b}, 11 \mathrm{~b}\end{array}$ & $\begin{array}{l}\text { - For 7OHMMeOP, T3 estimates were decreased compared to T1 }[\beta=-0.29 \\
\text { - }-0.59,0.01)] \text {. } \\
\text { Maternal phthalate metabolites concentrations were negatively associated with } \\
\text { BMIZ and overweight but significant associations was found between phthalate } \\
\text { metabolites and overweight at } T 2 \text { vs } T 1[R R=0.49(0.26,0.94)] \text {. }\end{array}$ \\
\hline (104) & $\begin{array}{l}\text { Cross- } \\
\text { sectional } \\
\text { (USA), } \\
\text { Female } \\
\text { (1690) }\end{array}$ & $\begin{array}{l}\text { MBP, MEP, MEHP, } \\
\text { MEHHP, MEOHP, } \\
\text { MECPP, MBzP }\end{array}$ & $\geq 18 y$ & $\geq 18 y$ & $\begin{array}{c}1,3,4 b \\
6 b, 7,8 \\
9 a, 6 f \\
10 a, 16 c\end{array}$ & $\begin{array}{l}\text { - MBP concentrations were associated with } \mathrm{BMI} \text { and WC }[\mathrm{OR}=1.13(1.03,1.23) \\
\text { and } \mathrm{OR}=1.13(1.03,1.24) \text {, respectively], and MEHP with only } \mathrm{BMI}[\mathrm{OR}=1.12 \\
(1.03,1.23)] \text {. } \\
\text { A higher ratio of MEHP to MEHHP was associated with } \mathrm{BMI}[\mathrm{OR}=1.21(1.09 \text {, } \\
\text { 1.34)] and WC [OR=1.20 }(1.10,1.31)] \text {. }\end{array}$ \\
\hline (105) & $\begin{array}{l}\text { Cross- } \\
\text { sectional } \\
\text { (Taiwan), } \\
\text { Adolescents } \\
(270)\end{array}$ & $\begin{array}{l}\text { LMWP (MMP, MEP, } \\
\text { MiBP, MBP) MEHP, } \\
\text { MEHHP, MECPP, } \\
\text { MEOHP, MBzP }\end{array}$ & $6.5-15 y$ & $6.5-15 y$ & $1,2,18 b$ & $\begin{array}{l}\text { - MEP, MiBP, MEOHP, MEHHP, MECPP, and LMWP were positively associated } \\
\text { with WC; MEP, MEOHP, MEHHP and LMWP were positively associated with } \\
\text { ST; MEP, MiBP, MEOHP, MEHHP, MECPP, LMWP, and PAEs were positively } \\
\text { associated with WHtR; MEP, MiBP, MBP, MEOHP, MEHHP, LMWP, and total } \\
\text { phthalate metabolites were positively associated with waist to hip ratio, and } \\
\text { MEP and MEHHP were positively associated with BMI. } \\
\text { - Indices (except HC) significantly increased among general adolescents with } 25- \\
75^{\text {th }} \text { and }>75^{\text {th }} \text { percentile of phthalate metabolites in compared with }<25^{\text {th }} \\
\text { percentile. }\end{array}$ \\
\hline (106) & $\begin{array}{l}\text { Cross- } \\
\text { sectional } \\
\text { (USA), } \\
\text { Children, } \\
\text { adolescents } \\
\text { and adults }\end{array}$ & $\begin{array}{l}\text { LMWP (MBP, MiBP, } \\
\text { MEP), HMWP (MEHP, } \\
\text { MECPP, MEHHP, } \\
\text { MEOHP, MBZP, MCNP, } \\
\text { MCOP) }\end{array}$ & $6-19 y, \geq 20 \quad y$ & $\begin{array}{l}6-19 y \\
\geq 20 y\end{array}$ & $\begin{array}{l}1,2,3 \\
4 a, 6 b, 7 \\
7 b, 8,9 c \\
10 a, 14 e \\
18 b\end{array}$ & 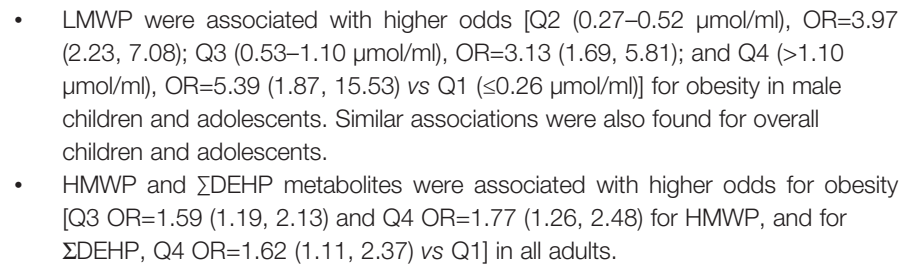 \\
\hline (107) & $\begin{array}{l}\text { Cross- } \\
\text { sectional } \\
\text { (China), } \\
\text { Children } \\
\text { (493) }\end{array}$ & $\begin{array}{l}\text { LMWP (MEP, MBP, } \\
\text { MMP), } \Sigma \text { MEHP (MEHP, } \\
\text { MEOHP, MEHHP) }\end{array}$ & $8-13 y$ & $8-13 y$ & $\begin{array}{l}4 b, 6 b \\
9 a, 16 b\end{array}$ & $\begin{array}{l}\text { - MBP and LMWP were positively associated with obesity in boys in a } \\
\text { concentration-effect manner. In the 11-13 y group, LMWP level was positively } \\
\text { associated with all obesity indices, including subscapular ST, WC and HC, \% } \\
\text { BF, BMI, BMIZ, and BSA. The Q3 and Q4 of MBP were significantly associated } \\
\text { with higher BSA, BMI, BMIZ, subscapular ST and HC. }\end{array}$ \\
\hline
\end{tabular}


TABLE 2 | Continued

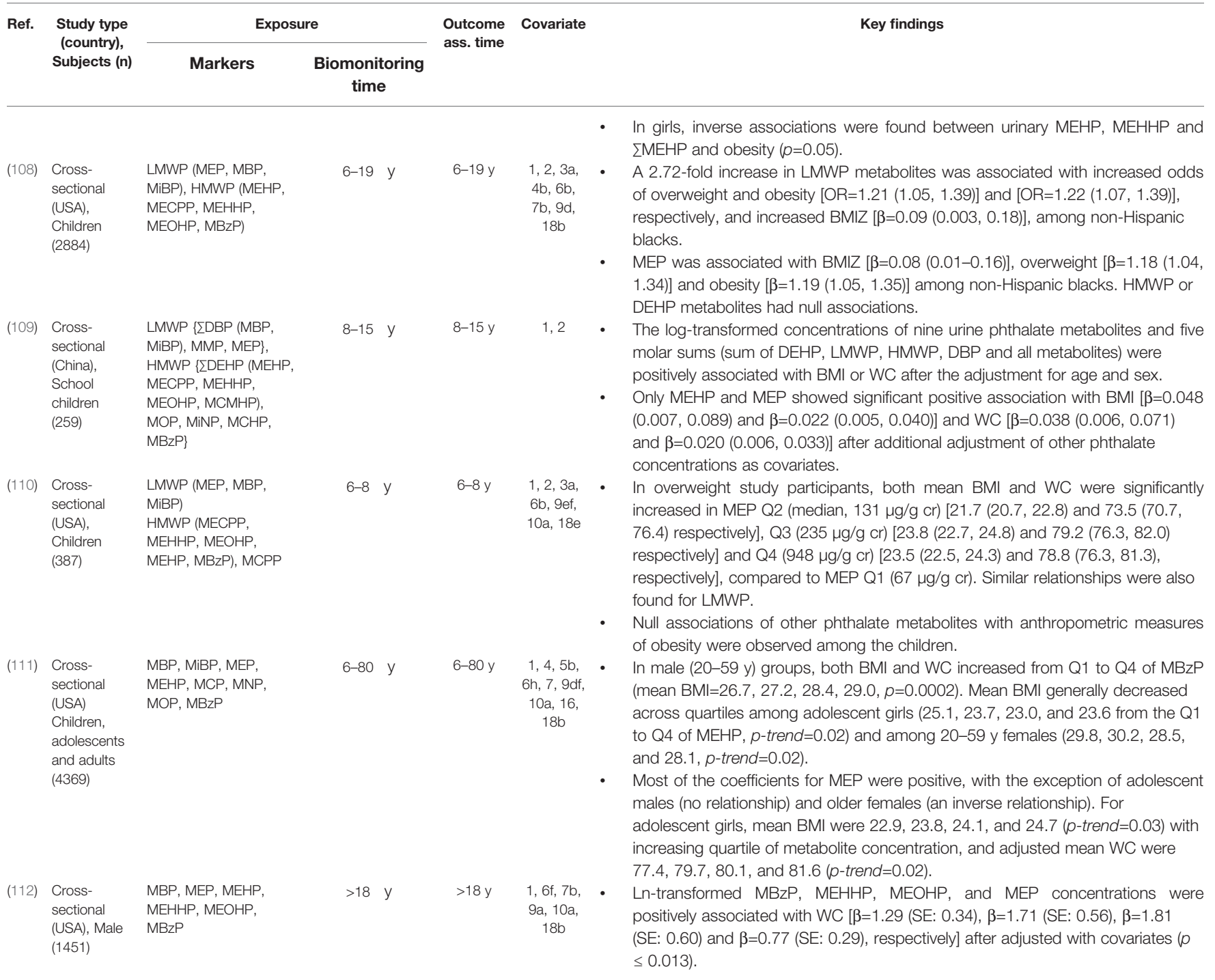

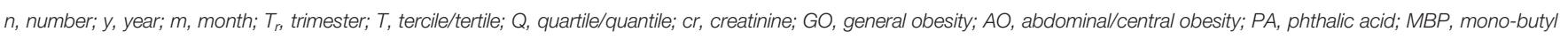

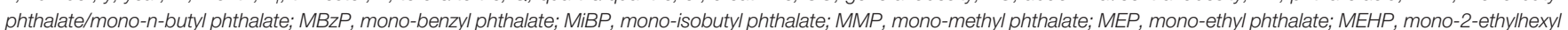

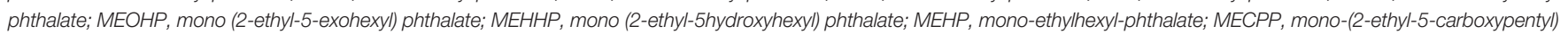

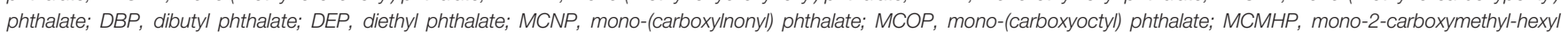

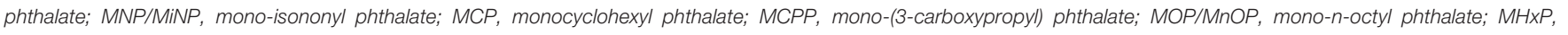

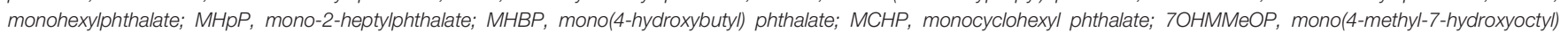

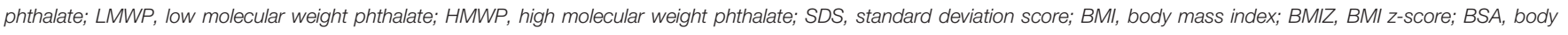

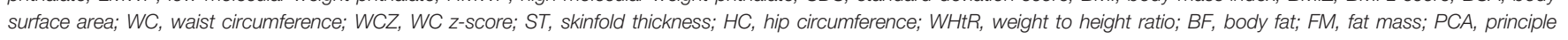
component analysis.

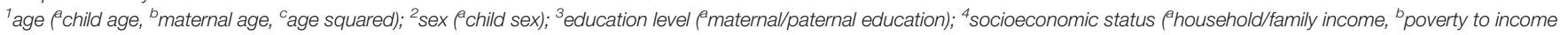
ratio, ${ }^{c}$ insurance, ${ }^{d}$ maternal receipt of public assistance); ${ }^{5}$ physique ( ${ }^{a}$ pre-pregnancy/maternal BMl, ${ }^{b}$ height, ${ }^{c}$ gestational weight gain, ${ }^{d}$ birth weight); ${ }^{6}$ food $\left({ }^{a}\right.$ maternal diet quality score,

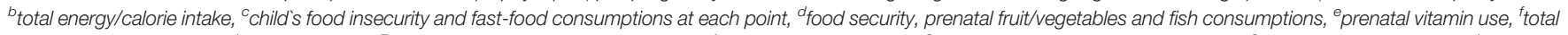

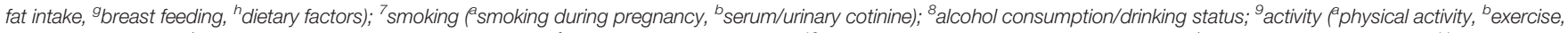

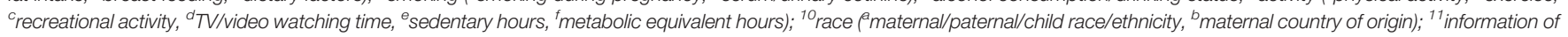

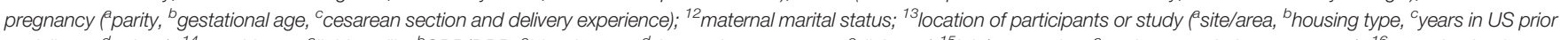

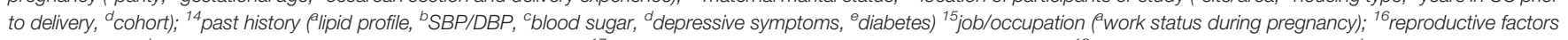

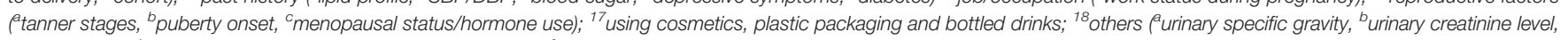

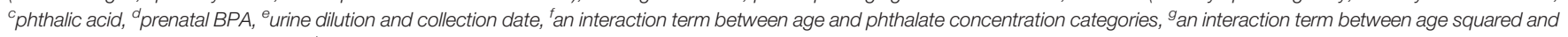
phthalate concentration categories, ${ }^{h}$ an interaction term between race/ethnicity and age).

[In all cases in the outcome, ranges within the first bracket indicate the 95\% Cl.] 
dependent association and found that higher maternal urinary concentrations of MCPP heightened the odds of being overweight or obese in Hispanics than in non-Hispanic blacks, although null associations were found with BMI (99). Prepubertal girls showed positive associations between \% MEHHP and BMI, WC, and \%BF, and showed significant odds increase in the $3^{\text {rd }}$ and $4^{\text {th }}$ quartiles compared to the $1^{\text {st }}$ quartile. The relationship was null in pubertal girls (90).

Data regarding the lowest threshold levels of phthalate metabolites for overweight or obesity outcomes in humans are limited. Low molecular weight phthalate (LMWP) metabolite concentrations $\geq 0.27 \mu \mathrm{mol} / \mathrm{ml}$ were associated with significantly increased overweight or obesity indices in male children and adolescents (106). Another study reported increased BMI and WC for median urinary MEP concentrations $\geq 131$ and $\geq 948 \mu \mathrm{g} / \mathrm{g}$ creatinine, respectively (110).

\section{Environmental POPs and Obesity}

A total of 41 human epidemiological studies (33 cohort and 8 cross-sectional studies) explored the relationships between in utero and early life exposure to POPs and anthropometric indices of overweight and obesity among infants, children, adults, and elderly populations (Table 3 ). The studies assessed POP levels in blood (serum/plasma) or umbilical cord blood (whole blood, serum/plasma).

A total of 8 epidemiological studies (7 cohort and one crosssectional study) investigated the associations of several PBDEs with anthropometric measures of obesity along with other POPs in children, adults, and elderly individuals. Inconsistent associations were documented (Table 3 and Matrix Table 4). PBDE congeners, including BDE28, BDE47, BDE99, BDE100, BDE153, and BDE154, were mainly associated with obesity indices. In most of the included studies, the BDE153 congener was negatively associated with one or more overweight or obesity indices in children and adults $(4,114,117,123,127)$. All other PBDE congeners (BDE28, BDE47, BDE99, BDE100, BDE154, BDE209, and sum of PBDE), except BDE154, showed null associations with obesity indices $(4,103,114,117,127,141$, $145)$. One study instead showed a positive association between BDE47 and BMI in adults $\geq 18$ years of age (117). Associations of PBDE congeners with obesity in elderly people aged $\geq 70$ years were null in two separate studies $(141,145)$. Early childhood exposure to PBDEs was negatively associated (BDE153) or inconsistent (others) with obesity indices, especially BMI and WC, at 7 years of age $(114,127)$.

Eleven birth cohort studies investigated the associations between in utero or maternal and childhood exposure to PFAS and obesity indices. Associations between maternal exposure levels of PFAS metabolites and obesity indices were inconsistent (Table 3 and Matrix Table 5). First- to $2^{\text {nd }}$-trimester exposure levels of PFOS and PFOA showed inconsistent associations with the obesity indices of infants and toddlers $(51,146)$. In contrast, almost all studies found positive associations between maternal PFOA concentrations and different obesity indices in overall and/or sex-stratified populations of preschoolers and school-aged children (3, 115, 121, 122, 124), with two exceptions: in utero PFOA exposure showed a null association with BMI, WC, and overweight in school-aged children $(120,137)$. In contrast, PFOS and other PFAS levels were inconsistently associated with anthropometric measures of overweight and obesity in preschoolers and school-aged children (113). Prenatal exposure levels of PFOA were positively associated only in adult females, but the associations were null for all PFASs when considering the overall population (138). However, exposure levels of PFAS in preschoolers and school-aged children mostly showed null or negative associations with overweight or obesity indices $(3,120,121)$. Gestational exposure levels of PFOA $\geq 4.3-6.4$ $\mathrm{ng} / \mathrm{ml}$ were associated with increased $\mathrm{WC}$ in the children $2-8$ years of age (122). In contrast, $1^{\text {st }}$ and $2^{\text {nd }}$ trimester exposure levels of PFOA $(0.5-\leq 7.10 \mathrm{ng} / \mathrm{ml}$ in boys and 1.10 to $\leq 6.70 \mathrm{ng} / \mathrm{ml}$ in girls) showed null associations with BMI or overweight at 7 years of age (137).

Positive, negative, or null associations have also been reported between in utero or prenatal and postnatal, and between early childhood to the elderly concerning exposure to OCs and overweight and obesity indices (Table 3 and Matrix Table 6) (103, 115-119, 121, 125, 126, 128-136, 139-145, 147-149). Maternal $1^{\text {st }}$ to $3^{\text {rd }}$ trimester blood and/or umbilical cord blood levels of OC metabolites, especially DDE and HCB levels, were positively associated with different anthropometric indices of obesity, whereas associations of PCBs, DDT metabolites, and $\beta$ $\mathrm{HCH}$ concentrations were null or positive in toddlers and preschoolers (115, 116, 126, 132, 142, 148). Inconsistent associations (positive and null) were also found between PCBs, DDT metabolites, DDE, $\mathrm{HCB}$, and $\beta-\mathrm{HCH}$ levels in the $1^{\text {st }}$ to $3^{\text {rd }}$ trimester maternal blood or umbilical cord blood and obesity indices in school-aged children (103, 118, 130, 133-136, 139, 149). One study found positive associations of 2-week postpartum HCB levels, but not other OCs, with anthropometric indices in 18month-old and 5-year-old children (121). Among the OCs, DDT and its metabolite DDE showed potent positive associations with obesity indices in the overall population or in school-aged boys and girls $(103,118,130,134,135)$. Only one study investigated the relationship between prenatal exposure levels of DDE and adult obesity measures, and subsequently addressed the positive associations of adults aged 20-50 years. PCBs showed null associations in the same study participants (147). Again, associations sometimes varied among the countries within the study. A prospective cohort study of 412 Norwegian and Swedish mother-child pairs observed a non-monotonic dose-response relationship between PCB-153 concentrations and child overweight/obesity among Swedish children at 5 years of age, but not in Norwegian children (115). Exposure levels of PCB153 and DDE metabolites in infants were not associated with obesity measures in preschool and school-aged children (133). Early childhood or preschooler exposure levels of $\mathrm{HCB}, \mathrm{DDE}$, and PCBs were negatively associated with anthropometric parameters in preschoolers (121). School-aged exposure levels of PCBs, DDE, and HCB showed inconsistent associations with obesity indices in school-aged children, adolescents, and adults $(125,129)$. Exposure levels of DDE and $\beta-\mathrm{HCH}$ in adults ( $\geq 18$ years) showed positive associations, $\mathrm{PCBs}$ showed inconsistent associations (positive and negative), and other OCs also showed null associations with different anthropometric indices of overweight and obesity (117, $119,128,131,143,144)$. OC exposure in elderly people also showed 
TABLE 3 | Associations of environmental persistent organic pollutants with anthropometric overweight and obesity indices.

\begin{tabular}{cccc}
\hline Ref. $\begin{array}{c}\text { Study type } \\
\text { (country), }\end{array}$ & Exposure & $\begin{array}{c}\text { Outcome } \\
\text { ass. time }\end{array}$ & Covariate \\
$\begin{array}{c}\text { Subjects } \\
\text { (n) }\end{array}$ & Markers & $\begin{array}{c}\text { Biomonitoring findings } \\
\text { time }\end{array}$ & \\
& \multicolumn{2}{c}{}
\end{tabular}

(4) Birth cohort 9 PBDEs At birth (cord (China), serum) Motherchild (318)

(51) Birth cohort PFHxS, PFOS, $11.3 \mathrm{GW}$ (Denmark), PFOA, PFNA, (median) Mother- PFDA child (649)

(3) Birth cohort (USA), Motherchild (212)

(113) Birth cohort (China), Motherchild (404)

PFOS, PFOA, $16 \mathrm{GW}$, at PFNA, PFHXS birth, 3, 8, $12 y$

(114) Cohort (USA), Children PBDEs (BDE 28, 47, 99, (206) $100,153)$

(115) Birth cohort PFOS, PFOA, (Norway 7 PCBs, HCB, and $\quad p, p^{\prime}$-DDE Sweden), oxychlordane, Mother- $\quad p, p^{\prime}$-DDT, $\beta$ child (412) $\mathrm{HCH}, \mathrm{t}-\mathrm{NC}$

$<20 \mathrm{GW}$
$3 \mathrm{~m}, \quad 1 \mathrm{a}, 2,3 \mathrm{a}, \quad$ - At $3 \mathrm{~m}$ and $18 \mathrm{~m}$ of age, $1 \mathrm{ng} / \mathrm{ml}$ increases in PFOA, PFNA, and PFDA were $18 \mathrm{~m} \quad 5 \mathrm{a}, 7 \mathrm{a}, \quad \quad$ associated with average increases in the PI SDS of $0.07(0.01,0.13), 0.24(0.08$,

11a, $17 \mathrm{a} \quad 0.41)$, and $0.60(0.18,1.02)$, respectively and BMI SDS of $0.18(0.02,0.34), 0.42$ (0.01, 0.84), and $0.04(-0.01,0.10)$, respectively.

- In girls aged $3 \mathrm{~m}$ and $18 \mathrm{~m}$, PFNA and PFDA concentrations were associated with increased BMI SDS [PFNA: $0.26(0.03,0.49)$, PFDA: $0.58(-0.03,1.19)]$ and PI SDS [PFNA: $0.36(0.13,0.59)$, PFDA: $1.02(0.40,1.64)]$. Associations were null in boys.

- $\quad$ PFNA and PFDA were positively associated with \%BF SDS at $3 \mathrm{~m}[\beta=0.20$ (0.06, $0.34)]$ and $[\beta=0.40(0.04,0.75)]$ for $1 \mathrm{ng} / \mathrm{ml}$ increases, respectively), but not at 18 $\mathrm{m}$.

12 y $\quad 1 \mathrm{ab}, 2 \mathrm{a}, \quad$ - Serum PFOA and PFHxS concentrations during pregnancy were associated with 3a, 5a, 7a, increase in AO across all anthropometric measures and overweight/obesity.

10a, 11a, - A 2-fold increase in prenatal PFOA concentration was associated with WtHR $12,16 \quad[\beta=0.02(0.00,0.03)]$ but not with $W C[\beta=2.0(-0.8,4.8)]$ and other obesity indices.

- $\quad$ PFOA and PFHxS concentrations during pregnancy were associated with higher overall obesity and $\mathrm{AO}$ across all measures in girls, while non consistent results found in boys.

- $\quad$ Childhood PFAS concentrations were not associated with adiposity measures.

y $\quad 1 \mathrm{a}, 3 \mathrm{a}, 5 \mathrm{a}, \quad$ - In girls, a 10-fold increase in PFBS concentration was associated with increases $7 \mathrm{~b}, 11 \mathrm{a}, \quad$ in $\mathrm{WC}[\beta=1.48(0.32,2.53)], \mathrm{FM}[\beta=0.50(0.008,0.99)], \% B F[\beta=1.79 \%(0.04$, 3.54)], and WHtR $[\beta=0.01(0.001,0.02)]$.

- Girls at T3 of PFBS concentrations had higher WC $[\beta=2.06(0.43,3.68)]$, FM $[\beta=0.79(0.08,1.51)]$, \%BF $[\beta=2.84(0.29,5.39)]$ and $W H t R[\beta=0.01(0.0008$, 0.03)] in compared with T1.

- Increased PFDoA concentrations were associated with lower WC $[\beta=-1.95$ $(-3.61,-0.3)]$, FM $[\beta=-0.93(-1.65,-0.2)]$, and $\% B F[\beta=-3.02(-5.61,-0.43)]$ at T2 compared with T1 girls. PFNA concentrations were associated with higher $\%$ BF [T3 vs T1: $\beta=2.16(0.07,4.25)]$ in boys. Other PFAS showed null associations with obesity indices.

8 y $1 \mathrm{ab}, 2 \mathrm{a}, \quad$ - A 10-fold increase in BDE153 concentration at 1, 2, 3, 5, and 8 y were $4 a, 5 a$ $6 a b, 7 a, 8$ $9 a b c, 10 a$,

$12,14 \mathrm{a}$ - A 10-fold increase in BDE153 concentration at 2, 5, and 8 y were associated associated with lower \%BF of $2.0 \%(-3.9,-0.1), 2.9 \%(-4.9,-0.9), 3.6 \%(-5.5$, $-1.7), 5.6 \%(-7.8,-3.4)$, and $6.9 \%(-9.1,-4.7)$, respectively. Associations were stronger in boys. with a decrease of $4.0 \mathrm{~cm}(-6.9,-1.1), 7.3 \mathrm{~cm}(-10.5,-4.0)$, and $9.3 \mathrm{~cm}$ $(-12.5,-6.1)$ in WC.

$1 \mathrm{a}, 3 \mathrm{a}$, $5 a b, 6 c$, $7 a, 10 b$,

$11 \mathrm{a} \quad$ Overall, a 2.72-fold increase in maternal serum PFOS and PFOA concentrations were associated with increased odds for child overweight/obesity [OR=2.04 $(1.11,3.74)$ and $\mathrm{OR}=1.61(0.75,3.46)$, respectively]. But greater odds were reported among Norwegian children $[O R=2.96(1.42,6.15)]$ for PFOS and [OR=2.90 (1.10, 7.63) for PFOA.

- $\quad$ PFOS and PCB153 concentrations in Swedish children showed dose-dependent

\begin{tabular}{|c|c|c|c|c|c|}
\hline (116) & $\begin{array}{l}\text { Birth cohort } \\
\text { (South } \\
\text { Africa), }\end{array}$ & $\begin{array}{l}\text { OCs (p, p } \\
\text { '-DDE, p, p } \\
\text { '-DDT) }\end{array}$ & Near delivery & $\leq 2 \mathrm{y}$ & $\begin{array}{c}1 \mathrm{a}, 3 \mathrm{a}, 4 \\
5 \mathrm{a}, 11 \mathrm{a}, \\
14 \mathrm{bc}\end{array}$ \\
\hline
\end{tabular}

\section{associations with child overweight/obesity.}

girls, maternal $\mathrm{p}, \mathrm{p}^{\prime}$-DDT level was associated with higher BMl-for-age $[\beta=0.22(0.10,0.35)]$, weight-for-height $[\beta=0.22(0.09,0.34)]$, and weight-for-age $[\beta=0.17(0.05,0.29)] . p, p^{\prime}$-DDE also showed similar associations in a single pollutant model, but not in a Bayesian kernel machine regression model. 
TABLE 3 | Continued

\begin{tabular}{|c|c|c|c|c|c|c|}
\hline \multirow[t]{2}{*}{ Ref. } & \multirow{2}{*}{$\begin{array}{l}\text { Study type } \\
\text { (country), } \\
\text { Subjects } \\
\text { (n) }\end{array}$} & \multicolumn{2}{|c|}{ Exposure } & \multirow{2}{*}{$\begin{array}{l}\text { Outcome } \\
\text { ass. time }\end{array}$} & \multirow[t]{2}{*}{ Covariate } & \multirow[t]{2}{*}{ Key findings } \\
\hline & & Markers & $\begin{array}{l}\text { Biomonitoring } \\
\text { time }\end{array}$ & & & \\
\hline & $\begin{array}{l}\text { Mother- } \\
\text { child (708) }\end{array}$ & & & & & \\
\hline (117) & $\begin{array}{l}\text { Birth cohort } \\
\text { (USA), } \\
\text { Women } \\
(468)\end{array}$ & $\begin{array}{l}9 \text { OCs, } 10 \\
\text { PBDEs, } 35 \\
\text { PCBs }\end{array}$ & $\geq 18 y$ & $\geq 18 y$ & 1, 4a, 13a & 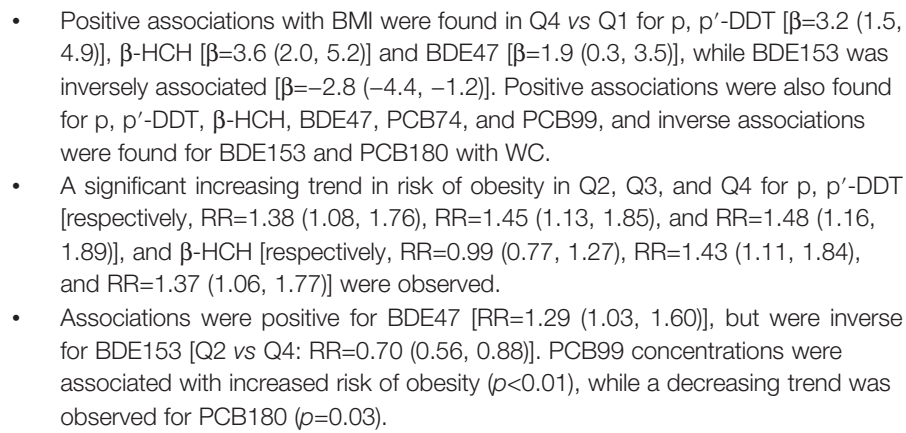 \\
\hline (118) & $\begin{array}{l}\text { Birth cohort } \\
\text { (USA), } \\
\text { Mother- } \\
\text { child (240) }\end{array}$ & $\begin{array}{l}\text { OCs (o, p } \\
\text { '-DDT, p, p } \\
\text { '-DDT, p, p } \\
\text { '-DDE) }\end{array}$ & $\begin{array}{l}26 \\
\text { GW }\end{array}$ & $12 \mathrm{y}$ & $4,5 a, 13 a$ & $\begin{array}{l}\text { - In boys, 10-fold increase in prenatal } 0, p^{\prime} \text {-DDT, } p, p^{\prime} \text {-DDT and } p, p^{\prime} \text {-DDE } \\
\text { concentrations were associated with increased } B M I Z \text { and } W C Z[\beta=0.37(0.08 \text {, } \\
0.65) \text { and } \beta=0.31(0.07,0.56)] ;[\beta=0.26(0.03,0.48) \text { and } \beta=0.25(0.05,0.45)] \text {, } \\
\text { and }[\beta=0.31(0.02,0.59) \text { and } \beta=0.27(0.01,0.53)] \text {, respectively. } \\
\text { Similarly, a } 10 \text {-fold increase in } 0, p^{\prime} \text {-DDT and } p, p^{\prime} \text {-DDT were associated with } \\
\text { increased risk of obesity [RR=1.46 }(1.07,1.97)] \text { and [RR=1.28 }(1.01,1.64)] \text {, } \\
\text { respectively. }\end{array}$ \\
\hline (119) & $\begin{array}{l}\text { Cross- } \\
\text { sectional } \\
\text { (Spain), } \\
\text { Adults (429) }\end{array}$ & $\begin{array}{l}30 \text { POPs } \\
\text { (includes } \\
\text { PCBs, DDTs, } \\
\text { DDEs) }\end{array}$ & $\geq 18 y$ & $\geq 18 y$ & $\mathrm{NC}$ & $\begin{array}{l}\text { - Median level of } p, p^{\prime}-D D E \text { among participants with } B M I \leq 25 \text { was significantly } \\
\text { lower than that of participants with } B M I \geq 25(0.83 \mu \mathrm{g} / \mathrm{l} \text { vs. } 1.26 \mu \mathrm{g} / \mathrm{l}, p<0.0001) \text {. } \\
\text { - } \mathrm{p}, \mathrm{p}^{\prime}-\mathrm{DDE} \text { identified as a risk factor for the development of overweight }[\mathrm{BMl} \geq 25 \text { : } \\
\text { Exo }(\mathrm{B})=1.38(1.15,1.64)] \text {, and obesity }[\mathrm{BMI} \geq 30 \text { : Exo }(\mathrm{B})=1.22(1.08,1.38)] \text {. }\end{array}$ \\
\hline (120) & $\begin{array}{l}\text { Birth } \\
\text { Cohort } \\
\text { (USA), } \\
\text { Mother- } \\
\text { child (1006 }\end{array}$ & $\begin{array}{l}\text { PFOA, PFOS, } \\
\text { PFHxS, PFNA }\end{array}$ & $<22$ GW & $\begin{array}{l}3.2,7.7 \text { y } \\
\text { (mean) }\end{array}$ & $\begin{array}{l}1 \mathrm{ab}, 2 \mathrm{a} \\
3 \mathrm{a}, 4 \mathrm{a} \\
10 \mathrm{a}, 11 \mathrm{a} \\
17 \mathrm{c}\end{array}$ & $\begin{array}{l}\text { - In girls in mid-childhood }(7.7 \mathrm{y}) \text {, each IQR increment of prenatal PFOA } \\
\left.\text { concentrations was associated with } 0.21 \mathrm{~kg} / \mathrm{m}^{2} \text { higher } \mathrm{BMI}(-0.05,0.48)\right], 0.76 \\
\text { mm higher sum of subscapular and triceps ST, }(-0.17,1.70)] \text {, and } 0.17 \mathrm{~kg} / \mathrm{m}^{2} \\
\text { higher total FMI }(-0.02,0.36)] \text { Similar associations were observed for PFOS, } \\
\text { PFHxS, and PFNA. }\end{array}$ \\
\hline & \& 876) & & & & & $\begin{array}{l}\text { - Null associations found for early-childhood (3.2 y) PFAS concentrations and } \\
\text { adiposity measures in boys and girls. }\end{array}$ \\
\hline (121) & $\begin{array}{l}\text { Birth cohort } \\
\text { (Faroe } \\
\text { Islands), } \\
\text { Mother- } \\
\text { child (444) }\end{array}$ & $\begin{array}{l}\text { HCB, DDE, } \\
\text { PFOS, PFOA, } \\
\text { PCBs, p, p'- } \\
\text { PFHxS, PFNA, } \\
\text { PFDA }\end{array}$ & $\begin{array}{l}2 \text { wk of } \\
\text { postpartum, } 5 \text { y }\end{array}$ & 18 m, 5 y & $\begin{array}{c}1 \mathrm{a}, 2 \mathrm{a} \\
5 \mathrm{abc}, 6 \mathrm{~d} \\
7 \mathrm{a}, 10 \mathrm{~b} \\
11 \mathrm{ab}\end{array}$ & $\begin{array}{l}\text { - A 10-fold increase in maternal } \mathrm{HCB} \text { concentrations were associated with } \\
\text { increased } \mathrm{BMIZ} \text { at } 18 \mathrm{~m}[\beta=0.15(0.01,0.30)] \text { and at } 5 \mathrm{y}[\beta=0.19(0.04,0.34)] \text {. } \\
\text { Similar associations were found between PFOS concentrations and } \mathrm{BMIZ} \\
{[\beta=0.23(0.04,0.42)] \text { and overweight risk }[\mathrm{RR}=1.29(1.01,1.64)] \text { at } 18 \mathrm{~m} \text {. }} \\
\text { Associations were null at } 5 \mathrm{y} . \mathrm{A}, 10 \text {-fold increase in maternal PFOA was } \\
\text { associated with the risk of being overweight at } 5 \mathrm{y}[\mathrm{RR}=1.50(1.01,2.24)] \text {. } \\
\text { Child serum-POPs (except PFHXS and DDE) levels inversely associated with } \\
\text { BMIZ or overweight risk at } 5 \mathrm{y} \text {. }\end{array}$ \\
\hline (122) & $\begin{array}{l}\text { Birth cohort } \\
\text { (USA), } \\
\text { Mother- } \\
\text { child (285) }\end{array}$ & $\begin{array}{l}\text { PFOA, PFOS, } \\
\text { PFNA, PFHXS }\end{array}$ & $\begin{array}{l}16 \mathrm{GW}, 26 \mathrm{GW} \\
\text { (mean) and at } \\
\text { birth }\end{array}$ & $2-8 y$ & $\begin{array}{c}\text { 1a, 3a, 4a, } \\
6 a e, 7 c \\
10 a, 11 a \\
12,14 a \\
15 a\end{array}$ & $\begin{array}{l}\text { - WC was higher among children in the T2 }(4.3-6.4 \mathrm{ng} / \mathrm{ml})[\beta=4.3(1.7,6.9)] \text { and } \\
\text { T3 }(6.6-25 \mathrm{ng} / \mathrm{ml})[\beta=2.2(-0.5,4.9)] \text { compared with } \mathrm{T} 1(0.5-4.2 \mathrm{ng} / \mathrm{ml}) \text { of } \\
\text { prenatal PFOA. } \\
\text { Between } 2 \text { and } 8 \mathrm{y} \text {, BMIZ increased at a greater rate among children at T2 } \\
{[\beta=0.44(0.23,0.64)] \text { and T3 }[\beta=0.37(0.14,0.60)] \text { of PFOA compared with T1 }} \\
{[\beta=0.12(-0.08,0.32)] \text {. }} \\
\text { Children born to women with T2 and T3 PFOA concentrations had increased } \\
\text { risk of overweight }[\mathrm{RR}=1.84(0.97,3.50)] \text { or obesity }[\mathrm{RR}=1.54(0.77,3.07)] \text { at } 8 \mathrm{y} \\
\text { compared to children born to women in the T1 category. }\end{array}$ \\
\hline (123) & $\begin{array}{l}\text { Birth cohort } \\
\text { (USA), } \\
\text { Mother- } \\
\text { child (318) }\end{array}$ & $\begin{array}{l}10 \text { PBDEs } \\
\text { (LPBDEs: } \\
\text { BDEs 28, 47, } \\
99,100,153)\end{array}$ & 16 GW (mean) & $1-8 y$ & $\begin{array}{c}1 \mathrm{a}, 3 \mathrm{a}, 4 \mathrm{a} \\
7 \mathrm{a}, 10 \mathrm{a} \\
14 \mathrm{a}, 6 \mathrm{~d}\end{array}$ & $\begin{array}{l}\text { - Ten-fold increases in BDE100 and } \sum \text { PBDEs were associated with decreased WC } \\
{[\beta=-1.50(-2.93,-0.08) \text { and } \beta=-1.57(-3.11,-0.02) \text {, respectively] among }} \\
\text { children } 4-8 \text { y in age. } \\
\text { In contrast, a 10-fold increase in BDE153 was associated with lower BMIZ }[\beta= \\
-0.36(-0.60,-0.13)] \text { at } 2-8 y \text { and lower } \% \text { BF }[\beta=-2.37(-4.21,-0.53)] \text { at } 8 \mathrm{y} \text {. }\end{array}$ \\
\hline (103) & $\begin{array}{l}\text { Birth cohort } \\
\text { (Spain), } \\
\text { Mother- } \\
\text { child (470) }\end{array}$ & $\begin{array}{l}27 \text { POPs } \\
\text { including } 6 \\
\text { OCs, } 6 \text { PBDEs }\end{array}$ & $1^{\text {st }}, 3^{\text {rd }} T_{r}$ & $7 y$ & $\begin{array}{c}1 a b \\
2 a, 4,5 a b c \\
6 c, 7 a \\
10 b, 11 c\end{array}$ & $\begin{array}{l}\text { - Maternal concentrations of } \mathrm{HCB}, \beta \mathrm{HCH}, \mathrm{PCB} 138 \text {, and } \mathrm{PCB} 180 \text { were associated } \\
\text { with increased child BMIZ, } \mathrm{HCB}, \beta \mathrm{HCH}, \mathrm{PCB} 138 \text {, and DDE with overweight risk. } \\
\text { In principle component analysis, the OC factors (DDE, HCB, } \beta \mathrm{HCH}, \mathrm{PCB} 138 \text {, } \\
\text { PCB153, PCB180) were positively associated with BMIZ [T3 vs. T1, } \beta=0.37 \\
(0.03,0.72)] \text { and with overweight [T3 vs. T1, RR=2.59 }(1.19,5.63)] \text {. }\end{array}$ \\
\hline
\end{tabular}


TABLE 3 | Continued

\begin{tabular}{|c|c|c|c|c|c|c|}
\hline \multirow[t]{2}{*}{ Ref. } & \multirow{2}{*}{$\begin{array}{l}\text { Study type } \\
\text { (country), } \\
\text { Subjects } \\
\text { (n) }\end{array}$} & \multicolumn{2}{|c|}{ Exposure } & \multirow{2}{*}{$\begin{array}{l}\text { Outcome } \\
\text { ass. time }\end{array}$} & \multirow[t]{2}{*}{ Covariate } & \multirow[t]{2}{*}{ Key findings } \\
\hline & & Markers & $\begin{array}{c}\text { Biomonitoring } \\
\text { time }\end{array}$ & & & \\
\hline (124) & $\begin{array}{l}\text { Birth cohort } \\
\text { (Greenland, } \\
\text { Ukraine), } \\
\text { Mother- } \\
\text { child (1022) }\end{array}$ & PFOA, PFOS & 24 GW (mean) & $5-9 y$ & $\begin{array}{c}1 \mathrm{ab}, 2 \mathrm{a}, \\
3 \mathrm{a}, 5 \mathrm{a}, 7 \mathrm{a}, \\
11 \mathrm{a}\end{array}$ & $\begin{array}{l}\text { - A 2.72-fold increase in pregnancy PFOA concentrations were associated with } \\
\text { increased risk of offspring overweight }[R R=1.11(0.82,1.53)] \text { in Greenlandic } \\
\text { children and }[R R=1.02(0.72,1.44) \text { in Ukrainian children. } \\
\text { - A } 2.72 \text {-fold increase of prenatal PFOA and PFOS were associated with } \\
\text { increased risk of having WHtR }>0.5[R R=1.30(0.97,1.74)] \text { and }[R R=1.38(1.05 \text {, } \\
\text { 1.82)], respectively, in the total study subjects. }\end{array}$ \\
\hline (125) & $\begin{array}{l}\text { Cross- } \\
\text { sectional } \\
\text { (Denmark), } \\
\text { Children } \\
\text { (509) }\end{array}$ & $\begin{array}{l}\text { PCBs, p, p } \\
\text { '-DDE, HCBs }\end{array}$ & $8-10 y$ & $\begin{array}{c}14-16,20 \\
-22 y\end{array}$ & $\begin{array}{c}3 \mathrm{a}, 4,5 \mathrm{ad} \\
6 \mathrm{c}, 7 \mathrm{a}\end{array}$ & $\begin{array}{l}\text { - Child } \Sigma \text { PCB concentrations were inversely associated with WC and \%BF in girls } \\
14-16 \text { y old }(p=0.04 \text { and } p=0.03 \text {, respectively). } \\
\text { - The inverse association between } \Sigma \text { PCB (PCB138, } 153 \text {, and } 180) \text { and BMIZ was } \\
\text { evident among those in the T3 }>0.28 \mu \mathrm{g} / \mathrm{g} \text { lipid) compared with the T1 }(<0.16 \\
\mu \mathrm{g} / \mathrm{g} \text { lipid) among women } 20-22 \text { y old }[\beta=-0.44(-0.80,-0.08)] \text {. }\end{array}$ \\
\hline (126) & $\begin{array}{l}\text { Birth cohort } \\
\text { (Greece), } \\
\text { Mother- } \\
\text { child (689) }\end{array}$ & $\begin{array}{l}\text { PCBs, DDE, } \\
\text { HCBs }\end{array}$ & $1^{s t} T_{r}$ & $4 y$ & $\begin{array}{c}1 \mathrm{ab}, 2 \mathrm{a} \\
3 \mathrm{a}, 5 \mathrm{ac} \\
6 c, 7 \mathrm{a} \\
11 \mathrm{ac}, 14 \mathrm{~b}\end{array}$ & $\begin{array}{l}\text { A 10-fold increase in maternal HCB concentrations was associated with a higher } \\
B M I Z[\beta=0.49(0.12,0.86)] \text {, obesity }[R R=8.14(1.85,35.81)], A O[R R=3.49(1.08 \text {, } \\
\text { 11.28)], and greater sum of } S T[\beta=7.71(2.04,13.39)] \text { at } 4 \text { y of age. } \\
\text { Prenatal DDE exposure was also associated with higher } B M I Z[\beta=0.27(0.04, \\
\text { 0.5)], } A O[R R=3.76(1.70,8.30)] \text {. }\end{array}$ \\
\hline (127) & $\begin{array}{l}\text { Birth cohort } \\
\text { (Canada), } \\
\text { Mother- } \\
\text { child } \\
(224 \& 216)\end{array}$ & $\begin{array}{l}10 \text { PBDEs, } \\
\text { (penta PBDE= } \\
\text { BDEs } 47,99 \\
100,153, \Sigma 4 \\
\text { PBDE) }\end{array}$ & $\begin{array}{l}26.7 \mathrm{GW} \\
\text { (mean), } 7 \text { y }\end{array}$ & $7 y$ & $\begin{array}{l}1 \mathrm{a}, 2,3 \mathrm{a} \\
4,5 \mathrm{ab} \\
6 \mathrm{df}, 11 \mathrm{c} \\
13 \mathrm{a}\end{array}$ & $\begin{array}{l}\text { - Maternal serum } \Sigma 4 \text { PBDE concentration was not associated with the BMIZ }[\beta= \\
-0.08(-0.41,0.25)] \text {, WCZ }[\beta=-0.02(-2.45,0.28)] \text {, or the odds of being } \\
\text { overweight }[O R=0.82(0.38,1.79)] \text { at } 7 \text { y of age. } \\
\text { A } 10 \text {-fold increase in } \Sigma 4 \text { PBDE concentration was associated with decrease } \\
\text { BMIZ in girls }[\beta=-0.41(-0.87,-0.05) \text { compared with boys }[\beta=0.26(-0.19 \text {, } \\
0.72)] \text {. } \\
\text { Child's serum BDE153 concentration showed inverse associations with BMIZ } \\
{[\beta=-1.15(-1.53,-0.77)] \text { and } \text { WCZ }[\beta=-0.95(-1.26,-0.64)] \text { at } 7 \text { y of age. }}\end{array}$ \\
\hline (128) & $\begin{array}{l}\text { Cross- } \\
\text { sectional } \\
\text { (USA), } \\
\text { Adults } \\
\text { (2358) }\end{array}$ & $\begin{array}{l}\text { POPs }(\beta-H C H, \\
\text { dioxins, PCBs } \\
\text { and few } \\
\text { others) }\end{array}$ & $\geq 20 y$ & $\geq 20 y$ & $\begin{array}{c}1,2,3,7 d \\
8,9 d, 10 a \\
11 a, 13 b\end{array}$ & $\begin{array}{l}\text { - } \beta \text { - } \mathrm{HCH} \text {, heptachlorodibenzo-p-dioxin, octachlorodibenzo-p-dioxin, and PCB126 } \\
\text { showed stronger positive correlations, whereas PCBs with } \geq 6 \text { chlorines inversely } \\
\text { correlated with trunk \%FM than with leg \%FM. } \\
\text { - Stronger inverse correlations existed between POPs and trunk \%FM mainly in } \\
\text { participants }<40 \text { y of age. Stronger positive correlations between POPs and } \\
\text { trunk \%FM were observed in older participants. }\end{array}$ \\
\hline (129) & $\begin{array}{l}\text { Cross- } \\
\text { sectional } \\
\text { (Belgium), } \\
\text { Child (114) }\end{array}$ & $\begin{array}{l}\text { PCBs, dioxins, } \\
\mathrm{p}, \mathrm{p}^{\prime} \text {-DDE } \\
\text {-DDE, HCB }\end{array}$ & At delivery & $7-9 y$ & $\begin{array}{c}1 \mathrm{ab}, 5 \mathrm{a} \\
3 \mathrm{a}, 7 \mathrm{a}\end{array}$ & $\begin{array}{l}\text { - In unadjusted analysis, prenatal exposure to } \mathrm{HCB} \text { and } \mathrm{p}, \mathrm{p}^{\prime} \text {-DDE were } \\
\text { significantly and positively associated with } \mathrm{BMIZ}, \mathrm{WC}, \mathrm{WH} \mathrm{H} \text {, and sum of four } \\
\text { ST. } \\
\text { - After adjustment, a } 2.72 \text {-fold increase in prenatal } \mathrm{p}, \mathrm{p}^{\prime} \text {-DDE concentrations were } \\
\text { associated with } \mathrm{WC}[\beta=1.02(1.00,1.03)] \text { and } \mathrm{WH} R[\beta=1.04(1.01,1.07)] \text { in } \\
\text { girls. }\end{array}$ \\
\hline (130) & $\begin{array}{l}\text { Birth cohort } \\
\text { (Faroe } \\
\text { Islands), } \\
\text { Mother- } \\
\text { child (656) }\end{array}$ & PCBs, DDE & 34 GW & $5 y, 7 y$ & $1 \mathrm{a}, 11 \mathrm{a}$ & $\begin{array}{l}\text { - The Q4 (>1.95 } \mu \mathrm{g} / \mathrm{g} \text { lipid) of prenatal PCB exposure was associated with } \\
\text { increased BMI }[\beta=2.07(0.59,3.55)] \text { at age } 7 \mathrm{y} \text { in girls with overweight mothers. } \\
\text { - High prenatal PCB and DDE exposure was associated with increased BM } \\
{[\beta=1.2(0.42,2.05) \text { and } \beta=1.11(0.30,1.92) \text {, respectively] and WC }[\beta=2.48(1.10 \text {, }} \\
\text { 3.85) and } \beta=2.21(0.84,3.56) \text {, respectively] from } 5 \text { to } 7 \text { y of age. } \\
\text { PCB was associated with increased WC in girls both with overweight ( } \beta=2.48) \\
\text { and normal-weight mothers }(\beta=1.25) \text {, whereas DDE was associated with } \\
\text { increased WC only in girls with overweight mothers }(\beta=2.21) \text {. }\end{array}$ \\
\hline (131) & $\begin{array}{l}\text { Cross- } \\
\text { sectional } \\
\text { (Belgium), } \\
\text { Adults (151) }\end{array}$ & $\begin{array}{l}28 \text { PCBs, p, p } \\
\text { '-DDE }\end{array}$ & $\geq 18 y$ & $\geq 18 y$ & $\mathrm{NC}$ & $\begin{array}{l}\text { - } \log _{10} \text {-transformed serum PCBs levels, but not } p, p^{\prime}-D D E \text {, showed an inverse } \\
\text { relationship with weight and BMI in spearman correlation analysis }(p<0.01) \text {. } \\
\text { - Total serum POPs levels (sum of } 28 \text { PCBs and } p, p^{\prime} \text {-DDE) were positively } \\
\text { associated with WC and WtHR }(p<0.01) \text {. }\end{array}$ \\
\hline (132) & $\begin{array}{l}\text { Birth cohort } \\
\text { (Spain) } \\
\text { Mother- } \\
\text { child (1198) }\end{array}$ & $\begin{array}{l}\text { DDT, DDE, } \\
\text { HCB, } \beta-H C H, \\
\text { PCBs }(153 \\
138,180)\end{array}$ & $1^{s t} T_{r}$ & $14 \mathrm{~m}$ & $\begin{array}{c}1 a b, 2 a, \\
3 a, 5 a, 6 c, \\
7 a, 10 b \\
13 c\end{array}$ & $\begin{array}{l}\text { - A } 10 \text {-fold increase in DDE and HCB were associated with overweight }[R R=1.15 \\
(1.03,1.28) \text { and } R R=1.19(1.05-1.34) \text {, respectively]. } \\
\text { Effect of } 10 \text {-fold increase in DDE on overweight was stronger in infants who were } \\
\text { breastfed } \leq 16 \text { weeks compared with those breastfed for a longer period } \\
{[R R=1.26(1.11,1.43) \text { and } R R=1.02(0.86,1.21) \text {, respectively]. }}\end{array}$ \\
\hline (133) & $\begin{array}{l}\text { Birth cohort } \\
\text { (Greenland, } \\
\text { Poland, } \\
\text { Ukraine), } \\
\text { Mother- } \\
\text { child (1109) }\end{array}$ & $\begin{array}{l}\text { PCB153, p,p } \\
\text { '-DDE }\end{array}$ & $\begin{array}{l}\text { 9-40 GW, } \\
12 \mathrm{~m}\end{array}$ & $5-9 y$ & $\begin{array}{c}1 \mathrm{a}, 3 \mathrm{a} \\
5 \mathrm{ae}, 6 \mathrm{c} \\
7 \mathrm{a}, 8,9 \mathrm{~d} \\
11 \mathrm{a}, 17 \mathrm{a}\end{array}$ & $\begin{array}{l}\text { - Null associations were found between pregnancy PCB153 and } p, p^{\prime}-D D E \text {, and } \\
\text { child BMI in T3 vs T1 were }[\beta=-0.07(-0.32,0.18)] \text { and }[\beta=-0.10(-0.30,0.10)] \text {, } \\
\text { respectively. } \\
\text { Null associations were also observed for estimated postnatal PCB153 and p, } p \\
\text { '-DDE concentrations during the first } 12 \mathrm{~m} \text { of life and BMl in T3 vs T1 }[\beta=0.12 \\
(-0.15,0.39)] \text { and }[\beta=-0.03(-0.20,0.27)] \text {, respectively, at } 5-9 \mathrm{y} \text {. }\end{array}$ \\
\hline
\end{tabular}

(Continued) 
TABLE 3 | Continued

\begin{tabular}{|c|c|c|c|c|c|c|}
\hline \multirow[t]{2}{*}{ Ref. } & \multirow{2}{*}{$\begin{array}{l}\text { Study type } \\
\text { (country), } \\
\text { Subjects } \\
\text { (n) }\end{array}$} & \multicolumn{2}{|c|}{ Exposure } & \multirow{2}{*}{$\begin{array}{l}\text { Outcome } \\
\text { ass. time }\end{array}$} & \multirow[t]{2}{*}{ Covariate } & \multirow[t]{2}{*}{ Key findings } \\
\hline & & Markers & $\begin{array}{c}\text { Biomonitoring } \\
\text { time }\end{array}$ & & & \\
\hline (134) & $\begin{array}{l}\text { Birth cohort } \\
\text { (USA), } \\
\text { Mother- } \\
\text { child (261) }\end{array}$ & $\begin{array}{l}\text { O, p'-DDT, p, } \\
\mathrm{p}^{\prime}-\mathrm{DDT}, \mathrm{p}, \mathrm{p} \\
\text { '-DDE }\end{array}$ & $26 \mathrm{GW}$ & $9 y$ & $5 a, 13 a$ & $\begin{array}{l}\text { - Among boys, 10-fold increases in lipid adjusted prenatal DDT and DDE } \\
\text { concentrations were associated with increased odds of being overweight or } \\
\text { obese [o, } p^{\prime} \text {-DDT: OR=2.5 (1.0, 6.3); } p, p^{\prime} \text {-DDT: OR=2.1 (1.0, 4.5); and } p, p \\
\text { '-DDE: OR=1.97 }(0.94,4.13)] \text {. } \\
\text { - Similar results were found for increased WC and o, } p^{\prime} \text {-DDT [OR=1.98 (0.95, } \\
\text { 4.11)], p, p'-DDT [OR=2.05 (1.10, 3.82)] and p, p'-DDE [OR=1.98 (0.97, 4.04). } \\
\text { Positive associations were also observed among prenatal exposure levels of DDT } \\
\text { and DDE metabolites with BMIZ, WCZ and \%BF. }\end{array}$ \\
\hline (135) & $\begin{array}{l}\text { Birth cohort } \\
(\text { USA), } \\
\text { Mother- } \\
\text { child (270) }\end{array}$ & DDT, DDE & $\approx 26 \mathrm{GW}$ & $2-7 y$ & $5 a c, 9 b$ & $\begin{array}{l}\text { - A 10-fold increase in o, } p^{\prime} \text {-DDT, } p, p^{\prime}-D D T \text { and } p, p^{\prime} \text {-DDE was associated with } \\
\text { obesity }\left[0, p^{\prime} \text {-DDT, OR=1.17 }(0.75,1.82) ; p, p^{\prime}-D D T, O R=1.19(0.81,1.74) ; p, p\right. \\
\text { '-DDE, OR=1.22 }(0.72,2.06)] \text {, and BMIZ }\left[p, p^{\prime} D D E, \beta=0.12(-0.11,0.35)\right] \text {. } \\
\text { Significant positive associations were found between DDT and DDE exposure } \\
\text { levels with increasing age }(2,3.5,5 \text {, and } 7 \mathrm{y}) \text { and obesity. }\end{array}$ \\
\hline (136) & $\begin{array}{l}\text { Birth cohort } \\
\text { (USA), } \\
\text { Mother- } \\
\text { child (1915) }\end{array}$ & $\begin{array}{l}11 \text { PCBs, } \beta- \\
\text { HCH, DDT, } \\
\text { HCB, t-NC } \\
\text { dieldrin }\end{array}$ & $3^{\text {rd }} T_{r}$ & $7 y$ & $\begin{array}{l}1 \mathrm{~b}, 3 \mathrm{a}, 4 \\
5 \mathrm{a}, 7 \mathrm{a} \\
10 \mathrm{a}, 11 \mathrm{~d} \\
13 \mathrm{c}, 14 \mathrm{~b}\end{array}$ & $\begin{array}{l}\text { - Null associations were found between exposure to OCs and BMI, and } \\
\text { overweight/obesity after adjustment of potential covariates. } \\
\text { Dieldren was associated with obesity [Q4 }(0.92-1.18 \mu \mathrm{g} / \mathrm{l}) \text { vs Q1 }(<0.57 \mu \mathrm{g} / \mathrm{l}) \text {, } \\
\text { OR=3.6 (1.3-10.5) and Q5 (>1.18 } \mu \mathrm{g} / \mathrm{l}) \mathrm{vs} \mathrm{Q} 1 \text {, OR=2.3 (0.8-7.1)]. }\end{array}$ \\
\hline (137) & $\begin{array}{l}\text { Birth cohort } \\
\text { (Denmark), } \\
\text { Mother- } \\
\text { child (1400) }\end{array}$ & PFOA, PFOS & $1^{\text {st }}-2^{\text {nd }} T_{r}$ & $7 y$ & $\begin{array}{l}1 \mathrm{ab}, 4,5 \mathrm{a} \\
7 \mathrm{a}, 10 \mathrm{a} \\
11 \mathrm{a}, 17 \mathrm{a}\end{array}$ & $\begin{array}{l}\text { - Maternal PFOS }(7.3 \text { to } \leq 44 \mathrm{ng} / \mathrm{ml} \text { for boys and } 6.4 \text { to } \leq 43.5 \mathrm{ng} / \mathrm{ml} \text { for girls) and } \\
\text { PFOA }(0.5 \text { to } \leq 7.10 \mathrm{ng} / \mathrm{ml} \text { for boys and } 1.10 \text { to } \leq 6.70 \mathrm{ng} / \mathrm{ml} \text { for girls) } \\
\text { concentrations were not associated with BMl or overweight at } 7 \mathrm{y} \text {. }\end{array}$ \\
\hline (138) & $\begin{array}{l}\text { Birth cohort } \\
\text { (Denmark), } \\
\text { Mother- } \\
\text { child (665) }\end{array}$ & $\begin{array}{l}\text { PFOA, PFAS, } \\
\text { PFOSA, PFNA }\end{array}$ & $30 \mathrm{GW}$ & $20 y$ & $\begin{array}{l}1 \mathrm{ac}, 3 \mathrm{a} \\
5 \mathrm{ac}, 7 \mathrm{a} \\
11 \mathrm{a}\end{array}$ & $\begin{array}{l}\text { - Maternal PFOA concentration was associated with } \mathrm{GO} \text { and } \mathrm{AO} \text { at female } \\
\text { offspring [Q4 vs Q1 (median: } 5.8 \mathrm{vs} .2 .3 \mathrm{ng} / \mathrm{ml}): \mathrm{RR}=3.1(1.4,6.9) \text { and } \mathrm{RR}=3.0 \\
(1.3,6.8) \text {, respectively]. } \\
\text { Maternal PFOS, PFOSA and PFNA concentrations were not associated with } \\
\text { offspring BMI and WC. }\end{array}$ \\
\hline (139) & $\begin{array}{l}\text { Birth cohort } \\
\text { (Spain), } \\
\text { Child (344) }\end{array}$ & $\begin{array}{l}\text { HCB, DDE, } \\
\text { DDT, PCBs }\end{array}$ & $\begin{array}{l}\text { At birth (Cord } \\
\text { blood) }\end{array}$ & $6.5 y$ & $\begin{array}{l}1 a, 3 a \\
5 a c, 6 b \\
7 a, 11 a \\
15 b\end{array}$ & $\begin{array}{l}\text { - Increased risk of overweight was observed in the T3 of cord blood PCB } \\
\text { concentrations }[T 3(>0.9 \mathrm{ng} / \mathrm{ml}) \text { vs } T 1(<0.6 \mathrm{ng} / \mathrm{ml}), \mathrm{RR}=1.70(1.09,2.64)] \text { and } \\
\text { the T2 of DDE exposure }[\mathrm{T} 2(0.7-1.5 \mathrm{ng} / \mathrm{ml}) \mathrm{vs} T 1(<0.7 \mathrm{ng} / \mathrm{ml}), \mathrm{RR}=1.67(1.10 \text {, } \\
\text { 2.55)], but null association with DDT exposure in overall population. } \\
\text { A significant association was found for PCBs and overweight in the T3 vs T1 in } \\
\text { girls }[R R=2.13(0.99,4.57)] \text { than in boys }[R R=1.43(0.82,2.48)] \text {. Similar } \\
\text { associations also found for DDE. }\end{array}$ \\
\hline$(140)$ & $\begin{array}{l}\text { Cross- } \\
\text { sectional } \\
\text { (USA), } \\
\text { Women } \\
\text { (109) }\end{array}$ & $\begin{array}{l}36 \text { PCBs, } 9 \\
\text { OCs, }\end{array}$ & $50-75$ y & $50-75$ y & $\begin{array}{l}1,3,4 a \\
5 c, 11 e \\
\quad 12\end{array}$ & $\begin{array}{l}\text { - Plasma PCB180 concentrations were negatively and significantly associated with } \\
\text { BMI, \%BF, subcutaneous fat, intra-abdominal fat, WC, hip circumference, and } \\
\text { WtHR. PCB118 showed significant positive associations with subcutaneous fat, } \\
\text { intra-abdominal fat, WC, and WtHR. } \\
\text { Conversely, PCB105 and p, } \mathrm{p}^{\prime} \text {-DDE were generally increased or showed null } \\
\text { association with these obesity indices. }\end{array}$ \\
\hline$(141)$ & $\begin{array}{l}\text { Cohort } \\
\text { (Sweden), } \\
\text { Elder } \\
\text { people }(970 \\
\& 511)\end{array}$ & $\begin{array}{l}16 \text { PCBs, } 3 \\
\text { OCs, BDE, } \\
\text { dioxin }\end{array}$ & 70,75 y & 70,75 y & $\begin{array}{c}6 \mathrm{~g}, 7 \mathrm{~d}, 8 \\
14 \mathrm{~b}, 9 \mathrm{e}\end{array}$ & $\begin{array}{l}\text { - In the cross-sectional analyses, concentrations of the less chlorinated PCBs, } \mathrm{p} \text {, } \\
\mathrm{p}^{\prime} \text { - DDE and dioxin had adjusted odds ratios of } 2 \text { to } 3 \text { for AO. Highly chlorinated } \\
\text { PCBs were inversely associated. } \\
\text { - In the prospective analyses, similar but slightly weaker associations were seen } \\
\text { between POPs and risk of development of abdominal obesity. }\end{array}$ \\
\hline (142) & $\begin{array}{l}\text { Birth cohort } \\
\text { (Spain), } \\
\text { Mother- } \\
\text { child (657) }\end{array}$ & $\begin{array}{l}\text { HCB, } 2,2 \text { DDE, } \\
2,2 \text { DDT, } \beta- \\
\mathrm{HCH}, 4 \text { PCBs }\end{array}$ & $1^{\text {st }} T_{r}$ & $14 \mathrm{~m}$ & $\begin{array}{l}1 \mathrm{ab}, 5 \mathrm{fg} \\
7 \mathrm{a}, 10 \mathrm{~b}\end{array}$ & $\begin{array}{l}\text { - A } 10 \text {-fold increase in prenatal serum DDE was associated with elevated BMIZ } \\
{[R R=1.50(1.11,2.03) \text { for normal pre-pregnancy-weight mothers, and } R R=1.40} \\
(1.12,1.75) \text { for all mothers] at } 14 \mathrm{~m} \text {. } \\
\text { OCs were positively associated with rapid weight gain and subsequent } \\
\text { development of overweight. }\end{array}$ \\
\hline (143) & $\begin{array}{l}\text { Cohort } \\
\text { (African and } \\
\text { white } \\
\text { American), } \\
\text { Adults (90) }\end{array}$ & $\begin{array}{l}8 \text { OCs, } 22 \\
\text { PCBs, PBB }\end{array}$ & $18-30 y$ & $18-30 y$ & $\begin{array}{l}1,2,5 d \\
10 a, 14 b\end{array}$ & $\begin{array}{l}\text { - Among OCs, } p, p^{\prime} \text {-DDE predicted higher } \mathrm{BMI} \text { forming inverted } \mathrm{U} \text {-shaped dose- } \\
\text { response relations at } 20 \text { y after adjusting for the baseline values ( } p_{\text {quadratic }}<0.01 \text {, } \\
\text { from Q1 to Q4). } \\
\text { Persistent PCBs with } \geq 7 \text { chlorides predicted higher BMl at } 20 \text { y with similar } \\
\text { dose-response curves. }\end{array}$ \\
\hline (144) & $\begin{array}{l}\text { Cross- } \\
\text { sectional } \\
\text { (Belgium), } \\
\text { Adults (144) }\end{array}$ & $\begin{array}{l}4 \text { PCBs, p, p } \\
\text { '-DDE, } \beta-\mathrm{HCH}\end{array}$ & $\geq 18 y$ & $\geq 18 y$ & $\mathrm{NC}$ & $\begin{array}{l}\text { - A significant negative correlation between serum levels of PCB153, 180, } 170 \\
\text { and sumPCBs, and BMI, WC, and \%FM in entire groups (lean and obese } \\
\text { together). } \\
\text { Conversely, } \beta-\mathrm{HCH} \text { showed significant positive correlation with WtHR, BMI, WC, } \\
\text { and \%FM in entire groups. }\end{array}$ \\
\hline
\end{tabular}


TABLE 3 | Continued

\begin{tabular}{|c|c|c|c|c|c|c|}
\hline \multirow[t]{2}{*}{ Ref. } & \multirow{2}{*}{$\begin{array}{l}\text { Study type } \\
\text { (country), } \\
\text { Subjects } \\
\text { (n) }\end{array}$} & \multicolumn{2}{|c|}{ Exposure } & \multirow{2}{*}{$\begin{array}{l}\text { Outcome } \\
\text { ass. time }\end{array}$} & \multirow[t]{2}{*}{ Covariate } & \multirow[t]{2}{*}{ Key findings } \\
\hline & & Markers & $\begin{array}{c}\text { Biomonitoring } \\
\text { time }\end{array}$ & & & \\
\hline$(145)$ & $\begin{array}{l}\text { Cross- } \\
\text { sectional } \\
\text { (Sweden), } \\
\text { Elder } \\
\text { people } \\
(890)\end{array}$ & $\begin{array}{l}16 \text { PCBs, } 3 \\
\text { OCs, BDE47, } \\
\text { dioxin }\end{array}$ & $70 y$ & $70 y$ & $\begin{array}{c}\text { 2, 3, 5hi, } \\
6 \mathrm{~g}, 7 \mathrm{~d}, 8 \\
9 \mathrm{~d}\end{array}$ & $\begin{array}{l}\text { - Plasma concentrations of the PCB105, PCB118 and HCB, TNK, and DDE were } \\
\text { all positively related to FM }(p \leq 0.03) \text {. Subjects in the Q5 for PCB105 and } \\
\text { PCB118 showed a mean FM that was } 4.8(3.0,6.7) \text { and } 4.6(2.8,6.5) \text { more than } \\
\text { subjects in the Q1. } \\
\text { In contrast, the PCB156, 157, 169, } 170,180,189,194,206 \text {, and } 209 \text { were } \\
\text { negatively related to FM ( } p=0.0001) \text {. For PCB194, subjects in the Q5 showed a } \\
\text { mean FM that was } 10.8 \text { less than subjects in the Q1. }\end{array}$ \\
\hline (146) & $\begin{array}{l}\text { Birth cohort } \\
\text { (Denmark) } \\
\text { Mother- } \\
\text { child (1400) }\end{array}$ & PFOA, PFOS & $1^{\text {st }}-2^{\text {nd }} T_{r}$ & $5 \mathrm{~m}, 12 \mathrm{~m}$ & $\begin{array}{c}1 \mathrm{a}, 4,5 a \\
6 c, 7 a \\
11 a, 17 a\end{array}$ & $\begin{array}{l}\text { - A } 1 \mathrm{ng} / \mathrm{ml} \text { increase in the maternal blood levels of PFOS were inversely } \\
\text { associated to children's weight, after adjustment }[\beta=-5.8(-10.4,-1.2)] \text { at } 12 \mathrm{~m} \text {. } \\
\text { - Maternal PFOA concentrations was also associated with BMIZ at } 12 \mathrm{~m} \text { of age } \\
{[\beta=-0.007(-0.011,-0.002)] \text {. }}\end{array}$ \\
\hline$(147)$ & $\begin{array}{l}\text { Birth cohort } \\
\text { (USA), } \\
\text { Mother- } \\
\text { child } \\
\text { (151\&129) }\end{array}$ & PCBs, DDE & $\begin{array}{l}\text { During } \\
\text { pregnancy }\end{array}$ & $20-50$ y & $\begin{array}{c}1 b, 5 a c h, \\
6 b, 11 f \\
13 b, 17 d\end{array}$ & $\begin{array}{l}\text { - Compared with maternal DDE levels of }<1.503 \mu \mathrm{g} / \mathrm{l} \text {, daughter weight was } 5.93 \mathrm{~g} \\
\text { higher when prenatal DDE levels were } 1.503-2.9 \mu \mathrm{g} / \mathrm{l} \text {, and } 9.92 \mathrm{~g} \text { if levels were } \\
>2.9 \mu \mathrm{g} / \mathrm{l} \text {, and offspring BMl was } 1.65 \text { times higher when prenatal DDE levels } \\
\text { were } 1.503-2.9 \mu \mathrm{g} / \mathrm{l} \text { and } 2.88 \text { if levels were }>2.9 \mu \mathrm{g} / \mathrm{l} \text {. } \\
\text { - Prenatal PCBs showed null associations with offspring weight and BMl. }\end{array}$ \\
\hline$(148)$ & $\begin{array}{l}\text { Birth cohort } \\
\text { (Belgium), } \\
\text { Mother- } \\
\text { infant (138) }\end{array}$ & $\begin{array}{l}5 \text { PCBs, HCB, } \\
\text { DDE }\end{array}$ & $\begin{array}{l}\text { At birth (Cord } \\
\text { blood) }\end{array}$ & $1-3 y$ & $\mathrm{NC}$ & $\begin{array}{l}\text { - Increasing concentrations of cord blood PCBs were associated with higher BMI } \\
\text { SDS values at } 1-3 \text { y of ages }[\beta=0.003(0.001) ; p=0.03] \text {. } \\
\text { - } p, p^{\prime} \text {-DDE had a small effect on BMI SDS in children of nonsmoking mothers but } \\
\text { smoking enhanced the relation between DDE and BMI SDS at } 3 \mathrm{y} \text {. }\end{array}$ \\
\hline (149) & $\begin{array}{l}\text { Birth cohort } \\
\text { (Spain), } \\
\text { Children } \\
(482)\end{array}$ & $\begin{array}{l}\text { HCB, } 7 \text { PCBs, } \\
p, p^{\prime}-D D E, p \text {, } \\
p^{\prime} \text {-DDT }\end{array}$ & $\begin{array}{l}\text { At birth (Cord } \\
\text { blood) }\end{array}$ & $6.5 y$ & $\begin{array}{c}1 \mathrm{ab}, 2,3 \mathrm{a} \\
5 \mathrm{cj}, 7 \mathrm{a} \\
11 \mathrm{a}\end{array}$ & $\begin{array}{l}\text { - Children with HCB levels }>1.03 \mathrm{ng} / \mathrm{ml} \text { in cord blood had a higher } \mathrm{BMI}[\beta=0.80 \\
\text { (SE:0.34)] than children with } \mathrm{HCB} \text { levels }<0.46 \mathrm{ng} / \mathrm{ml} \text {. } \\
\text { Prenatal exposure to } \mathrm{HCB} \text { was also associated with an increased risk of being } \\
\text { overweight }[\mathrm{RR}=1.69(1.05,2.72)] \text { and obese }[\mathrm{RR}=2.02(1.06,3.85)] \text { at } 6.5 \mathrm{y} \text {. } \\
\text { - A } 10 \text {-fold increase in } \mathrm{HCB} \text { concentrations at birth associated with reduced BMl } \\
\text { and weight at age } 6.5(\beta=0.39 \text { and } 0.84 \text {, respectively), in the children from } \\
\text { normoweight women. }\end{array}$ \\
\hline
\end{tabular}

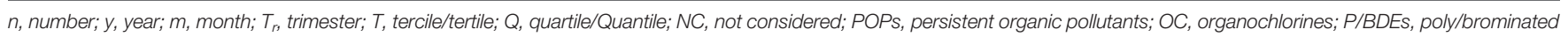
diphenyl ethers; PFAS, per and polyfluoroalkyl substances; PFOA, perfluorooctanoate; PFOS, perfluorooctane sulfonate; PFOSA, perfluorooctane sulfonamide; PFNA,

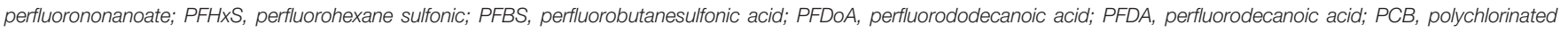
biphenyl; HCB, hexachlorobenzene; DDE, dichlorodiphenyldichloroethylene; DDT, dichlorodiphenyltrichloroethane; $\beta$-HCH, $\beta$-hexachlorohexane; $t$-NC, trans-nonachlor; TNK, transnonachlordane, SDS, standard deviation score; IQR, inter quartile range; GW, weeks of gestation; RR, relative risk; OR, odd ratio; BMI, body mass index; BMIZ, BMI Z-Score; FM, fat mass; BF, body fat, ST, skinfold thickness; WC, waist circumference; WCZ, WC z-score; WHtR, waist to height ratio; WtHR, weight to height ratio; PI, ponderal index; GO, general obesity; $A O$, abdominal/central obesity.

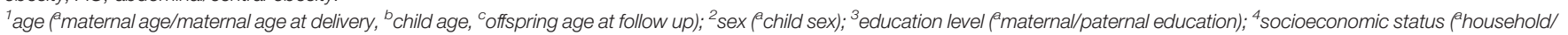
family income); ${ }^{5}$ physique ( ${ }^{\circ}$ pre-pregnancy/maternal BMI, ${ }^{b}$ gestational weight gain, ${ }^{c}$ birth weight, ${ }^{d}$ baseline BMI/obesity, ${ }^{e}$ paternal BMI, ${ }^{f}$ parental overweight/obesity, ${ }^{9}$ rapid growth status,

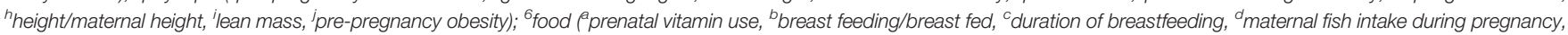
${ }^{e}$ maternal diet, ${ }^{f}$ child diet, ${ }^{9}$ total energy/calorie intake); ${ }^{7}$ smoking ${ }^{3}$ active/passive smoking during pregnancy, ${ }^{b}$ paternal smoking during pregnancy, ${ }^{c}$ maternal serum cotinine, ${ }^{d}$ Cigarette

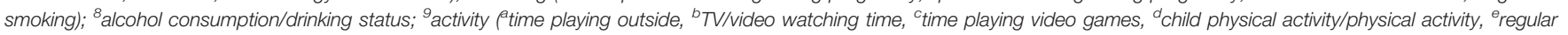

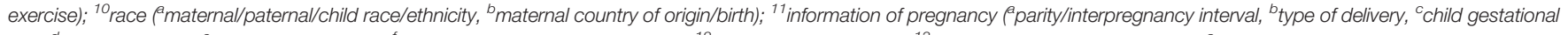

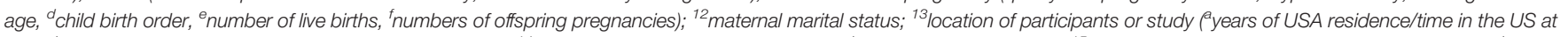

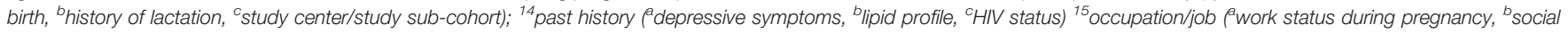

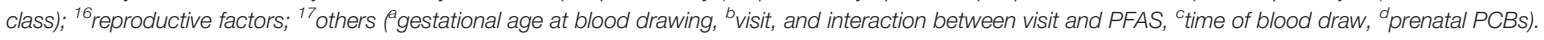

[In all cases in the outcome, ranges within the first bracket indicate the $95 \% \mathrm{Cl}$ ].

contradictory findings. DDE exposure levels showed positive or null associations, whereas PCBs showed very inconsistent associations (positive, negative, and null) with anthropometric indices in elderly people aged 50 to 75 years $(140,141,145)$. Furthermore, cord blood HCB levels $>1.03 \mathrm{ng} / \mathrm{ml}$ were associated with increased BMI in children at 6.5 years of age (149).

\section{DISCUSSION}

\section{Controversies and Elucidation}

We present evidence of the relationship between urinary/blood levels of selected EOs and their metabolites or congeners, and anthropometric overweight and obesity indices. These relationships are contentious. Prenatal or in utero, newborn, and early childhood to elder life exposure to selected EOs might contribute to the development of adiposity at different stages of life, although the findings were inconsistent depending on exposure and outcome assessment periods. Some studies have clarified positive associations, whereas other studies described negative or null associations for the same EO exposure levels and the subsequent anthropometric indices of obesity (Tables 1-3).

A representative example is two separate birth cohort studies from China and the United States $(8,72)$ with almost the same number of children (430 and 408). The studies indicated contradictory associations of BPA concentrations at age 3 years with anthropometric obesity indices at age 7 years. The study from China found positive associations, whereas the US study 
found null associations, despite the same exposures and outcome ages $(8,72)$. Many other studies have also reported contradictory findings among the same exposure and outcome age groups (Tables 1-3). In contrast, some studies conducted in different countries recruiting different populations reported similar associations between the same or different EO and obesity outcomes $(7,34,62,82,83,89,92)$. These conflicting findings across studies might be explained by methodological variations, particularly the characteristics of the study populations. Other potential reasons are exposure levels (low, medium, or high) and the timing and duration of EO exposure. Associations seem to differ between boys and girls, adult males, and females (Tables 1-3). Some studies reported ethnicity-specific associations between EO exposure and obesity indices (83, 99, 112). The reasons for racial and ethnic differences in overweight and obesity are largely unknown. Possible reasons might be the different patterns of calorie intake or energy consumption, physical activity, metabolic activity, endocrine, and genetic susceptibility among racial and ethnic groups $(150,151)$.

Among the environmental phenols, BPA has been widely investigated and has been positively associated with anthropometric overweight and obesity indices, mainly in school-aged children, adolescents, and adults. The use of BPA has been decreasing to reduce its negative health impact. This has led to increased use of BPS and BPF. Several studies investigated the association of BPS and BPF with obesity measures and described inconsistent relationships $(7,34,48,50,67)$. These few studies might be insufficient to conclusively determine the reason for the contradictory associations. Both DEHP and nonDEHP metabolites showed inconsistent associations with overweight and obesity indices at different stages of life. Among the non-DEHP metabolites, MEP, MMP, and MBzP seem to have obesogenic roles in adult and elderly humans. Among the POPs, DDE and PFOA showed almost consistent positive associations with obesity. PFOS also seems to be positively associated with obesity measures, but the associations were sometimes inconsistent. Compared with DDE, DDT showed a weaker association with obesity indices. Although DDT and DDE have already been banned in many countries, the long half-lives of these EOs (7 and 10 years for DDT and DDE, respectively) in both the environment and humans might be responsible for the adverse effects (152-157). Similarly, PFAS metabolites are also very persistent in the environment (half-lives of 3-10 years) and humans are exposed through ingestion of contaminated food, drinking water, and ingestion or inhalation of PFAS from contaminated dust and soil, and even via transplacental and breast milk passage from mother to child (158-163).

Usually, a single EO or a group of similar EOs was included in previous studies, making the results straightforward and easily interpretable. The rising concern is that generalized linear regression can provide a simple relationship between a single chemical or a group of similar chemicals and outcomes, but cannot explore the joint effect of mixed exposure (48). In addition, to study causality, researchers need to consider mixed environmental exposures and their complex nonlinear interactions. Eventually, ignoring the joint effects of other chemicals could contribute to false-positive or false-negative results (164). We found only a limited number of studies that investigated the associations between cumulative exposure to EOs and overweight and obesity indices using a multipollutant approach. Findings were inconsistent $(48,103,116,117)$. In one study, the associations of phthalate metabolites and bisphenols with obesity indices varied when considering single and cumulative exposure levels using three different statistical models (48). Thus, the application of a multipollutant statistical model to clarify the joint effects of mixed EOs should be accepted and utilized to explore the effect of a cumulative exposure burden on the outcomes in one direction per occasion, and the exposure-response function of each chemical, while controlling other chemicals at certain levels.

Some EOs (e.g., bisphenols and phthalates) are lipophilic. They can accumulate in adipose tissue of obese women and can influence the development of obesity in their offspring. A recent population-based prospective cohort of 1396 mothers showed that women in highest group of pre-pregnancy BMI $\left(>30 \mathrm{~kg} / \mathrm{m}^{2}\right)$ had significant higher concentrations of BPS [OR $=0.15(0.01$, $0.27)$ total bisphenols (sum of BPA, BPS, and BPF) $[\mathrm{OR}=1.88$ $(0.13,4.78)]$, phthalic acid $[\mathrm{OR}=13.16(2.51,29.86)]$, high molecular weight phthalate (HMWP) $[\mathrm{OR}=46.73$ (14.56, 93.72)] and DEHP $[\mathrm{OR}=32.34(6.90,70.75)]$ concentrations in comparison to women in normal pre-pregnancy BMI (20$24.9 \mathrm{~kg} / \mathrm{m}^{2}$ ) group (165). Another study found that prenatal exposure to PCBs $(>1.95 \mu \mathrm{g} / \mathrm{g}$ lipid) was associated with increased BMI in girls from overweight mothers, but not in normal-weight mothers (130). Thus, pre-pregnancy BMI is an important confounder that must be considered when investigating obesity outcomes in a birth cohort. Three studies considered pre-pregnancy BMI as a confounder in birth cohorts $(103,132,142)$. Adjustment of pre-pregnancy BMI might shed light on the relationship between EO exposure and obesity.

Daily consumable items (diet or foods and personal care products) are an important route of exposure to several EOs and are intrinsically related to energy balance. BPA and phthalate exposures occur primarily through ingestion and dermal absorption, as these compounds are found in common consumer goods, such as food containers, children's toys, and personal care products (166-169). Thus, it can be predicted that those who consume or use more of these products are more likely to have higher exposure levels and, perhaps, are more likely to be obese. Several studies reported a direct link between dietary exposure to EOs and obesity $(41,83,85)$. Most of the studies in the current review considered diet, calorie intake, energy consumption, and physical activity as potential confounders to address the relationships that strengthen the findings (Tables 1-3).

Puberty features hormonal transition. Both girls and boys undergo physical changes. Puberty has been associated with the development of obesity (170). Several studies evaluated the relationship between EOs and anthropometric measures of obesity in an age- and sex-specific manner before and after puberty $(7,61,66,72,73,78,79,81,96)$. A sex-stratified analyses 
found that increased exposure to urinary concentrations of BPA was positively associated with the sum of skinfold thickness (ST) in girls, while exposure to MEHP, MEHHP, MECPP, and MEOHP were inversely related to BMI z-score, WC, and the sum of ST in boys (70). However, when the analyze was restricted to children who had not yet begun the pubertal transition, the results shifted and showed positive relationships between BPA in girls and MEHP in boys with the sum of ST. In the prenatal exposure period, the authors observed an inverse relationship between MBzP and a child's BMI z-score, but this finding did not persist when the analyses were restricted to children prior to puberty. In a case-control study, prepubertal girls showed positive associations between \%MEHHP and BMI, WC, and \% $\mathrm{BF}$, and showed significantly increased odds in the $3^{\text {rd }}$ and $4^{\text {th }}$ quartiles compare to the $1^{\text {st }}$ quartile, whereas the relationship was null in pubertal girls (90). How the associations differ before and after puberty is not yet clearly understood. Knowledge of hormone levels related to pubertal growth, including thyroid hormones, leptin, adiponectin, and others, might provide more insight into the potential mechanisms of EO-mediated $s$ adiposity (171).

\section{Research Gap}

One of the limitations of the birth cohort studies outlined here is the use of single spot urine during the $1^{\text {st }}, 2^{\text {nd, }}$ or $3^{\text {rd }}$ trimester to estimate EO exposure. The biological half-lives of some of these chemicals are short and they are quickly excreted in urine (e.g., phthalates and bisphenols). Epidemiologists ideally prefer to use 24 $\mathrm{h}$ urine and repeated urine sampling when assessing these chemicals in relation to obesity, which occurs incrementally over time and has a multifactorial etiology $(172,173)$. The time of the day or season could account for some intrapersonal or interpersonal variations in urinary concentrations of analytes in single spot urine samples (174-177). However, single spot is the conventional test, despite these methodological limitations. In most of the included studies, biomonitoring EOs were done using methods lacking validated external quality assurance. Maintaining internal and external quality control and quality assurance might make study findings comparable and could strengthen the findings. Some studies had very limited information on pre-pregnancy BMI due to the availability of self-reported weight and the timing of recruitment in their original birth cohorts. These studies relied on maternal BMI. However, most of the studies collected data using self-reported questionnaires or home visits. Therefore, under- or over-estimated data could not be avoided. There was little or no data of phthalate metabolite (both DEHP and non-DEHP) levels and subsequent obesity assessment in infants and toddlers (Matrix Tables 2, 3). In addition, the assessment of obesity in adolescents related to $\mathrm{OC}$ (DDT, DDE, $\beta-\mathrm{HCH}, \mathrm{HCB}$, and PCBs) exposure was insufficient (Matrix Table 6). Very few studies investigated the relationship between cumulative EO exposure levels and overweight or obesity indices. Therefore, the possibility that prenatal and/or postnatal exposure to other unmeasured chemicals correlated with measured chemicals may have confounded the associations under study cannot be excluded. Finally, there are scant data concerning the trajectories of exposure and outcome assessments.

\section{Future Contemplations and Research Design}

Environmental epidemiologists should clearly infer whether exposure to ECs might influence weight gain or obesity, or whether obese study participants might have greater exposure to, or excretion of, ECs by conducting long-term follow-up studies in child and adult populations. Further prospective studies should aim to collect data with repeated measures over extended periods to improve exposure classification, increase general understanding of the timing of exposure, and address the temporal relationship between ECs and obesity. Given the gradual decrease of some ECs and increase exposure to some alternate ECs in human populations, continued biomonitoring of these alternate ECs and further investigations on their obesogenic effects in humans could be undertaken. Researchers should target study participants at all stages of life to assess exposure and obesity outcomes at each age. Many other chemicals, including pesticides, heavy metals, and particulate matter, have been reportedly associated with obesity outcomes in vitro and in vivo in animal studies. However, their obesogenic effects have not yet been completely evaluated in humans (178-186). Thus, an exposome-based approach needs to be developed to investigate the possible obesogenic effects of chemicals, xenobiotics, and pollutants in humans to explore the overall scenario of cumulative exposure. Studies of the obesogenic effects of ECs in the context of diet, stress, ethnicity, gender, and other factors, using sophisticated statistical models to assess complex exposures should be done.

\section{CONCLUSIONS}

The collective data indicate that BPA, DDE, and PFOA have consistent obesogenic effects in humans. Other bisphenols, phthalates, and POP metabolites or congeners have contradictory relationships with obesity at different outcome assessment times. Further prospective cohort studies with cumulative exposure assessments are required. The findings of this review will increase the awareness of the obesogenic effects of ECs among the general population.

\section{AUTHOR CONTRIBUTIONS}

NCM: investigation, data curation, analysis, and writing-original draft. SK: data curation and writing-review and editing. YI and MK: conceptualization, project administration, funding acquisition, supervision, and writing-review and editing. All authors contributed to the article and approved the submitted version.

\section{FUNDING}

This research was conducted with the support of the Grants-inAid for Scientific Research $19 \mathrm{H} 01078$ and $19 \mathrm{H} 03888$ provided by the Japan Society for the Promotion of Science (JSPS). 


\section{ACKNOWLEDGMENTS}

The first author is grateful to the Department of Biochemistry and Molecular Biology, Shahjalal University of Science and Technology, Sylhet, Bangladesh, for approval of his study leave.

\section{REFERENCES}

1. Allison DB, Downey M, Atkinson RL, Billington CJ, Bray GA, Eckel RH, et al. Obesity as a Disease: A White Paper on Evidence and Arguments Commissioned by the Council of the Obesity Society. Obesity (Silver Spring) (2008) 16(6):1161-77. doi: 10.1038/oby.2008.231

2. Lim JE, Choi B, Jee SH. Urinary Bisphenol A, Phthalate Metabolites, and Obesity: Do Gender and Menopausal Status Matter? Environ Sci Pollut Res Int (2020) 27(27):34300-10. doi: 10.1007/s11356-020-09570-X

3. Liu Y, Li N, Papandonatos GD, Calafat AM, Eaton CB, Kelsey KT, et al. Exposure to Per- and Polyfluoroalkyl Substances and Adiposity at Age 12 Years: Evaluating Periods of Susceptibility. Environ Sci Technol (2020) 54 (24):16039-49. doi: 10.1021/acs.est.0c06088

4. Guo J, Miao W, Wu C, Zhang J, Qi X, Yu H, et al. Umbilical Cord Serum PBDE Concentrations and Child Adiposity Measures at 7 Years. Ecotoxicol Environ Saf (2020) 203:111009. doi: 10.1016/j.ecoenv.2020.111009

5. Sommer I, Teufer B, Szelag M, Nussbaumer-Streit B, Titscher V, Klerings I, et al. The Performance of Anthropometric Tools to Determine Obesity: A Systematic Review and Meta-Analysis. Sci Rep (2020) 10(1):12699. doi: 10.1038/s41598-020-69498-7

6. World Health Organization. Obesity and Overweight. Available at: https:// www.who.int/news-room/fact-sheets/detail/obesity-and-overweight (Accessed Accesssed August 30, 2021).

7. Liu B, Lehmler HJ, Sun Y, Xu G, Sun Q, Snetselaar LG, et al. Association of Bisphenol A and Its Substitutes, Bisphenol F and Bisphenol S, With Obesity in United States Children and Adolescents. Diabetes Metab J (2019) 43 (1):59-75. doi: 10.4093/dmj.2018.0045

8. Guo J, Zhang J, Wu C, Xiao H, Lv S, Lu D, et al. Urinary Bisphenol A Concentrations and Adiposity Measures at Age 7 Years in a Prospective Birth Cohort. Chemosphere (2020) 251:126340. doi: 10.1016/ j.chemosphere.2020.126340

9. James PT, Leach R, Kalamara E, Shayeghi M. The Worldwide Obesity Epidemic. Obes Res (2001) 9 Suppl 4:228s-33s. doi: 10.1038/oby.2001.123

10. Poirier P, Giles TD, Bray GA, Hong Y, Stern JS, Pi-Sunyer FX, et al. Obesity and Cardiovascular Disease: Pathophysiology, Evaluation, and Effect of Weight Loss. Arterioscler Thromb Vasc Biol (2006) 26(5):968-76. doi: 10.1161/01.ATV.0000216787.85457.f3

11. Patterson RE, Frank LL, Kristal AR, White E. A Comprehensive Examination of Health Conditions Associated With Obesity in Older Adults. Am J Prev Med (2004) 27(5):385-90. doi: 10.1016/j.amepre.2004.08.001

12. Klein S, Burke LE, Bray GA, Blair S, Allison DB, Pi-Sunyer X, et al. Clinical Implications of Obesity With Specific Focus on Cardiovascular Disease: A Statement for Professionals From the American Heart Association Council on Nutrition, Physical Activity, and Metabolism: Endorsed by the American College of Cardiology Foundation. Circulation (2004) 110(18):2952-67. doi: 10.1161/01.Cir.0000145546.97738.1e

13. Vincent HK, Vincent KR, Seay AN, Hurley RW. Functional Impairment in Obesity: A Focus on Knee and Back Pain. Pain Manag (2011) 1(5):427-39. doi: $10.2217 / \mathrm{pmt} .11 .39$

14. Pimenta FB, Bertrand E, Mograbi DC, Shinohara H, Landeira-Fernandez J. The Relationship Between Obesity and Quality of Life in Brazilian Adults. Front Psychol (2015) 6:966. doi: 10.3389/fpsyg.2015.00966

15. Busutil R, Espallardo O, Torres A, Martínez-Galdeano L, Zozaya N, HidalgoVega Á. The Impact of Obesity on Health-Related Quality of Life in Spain. Health Qual Life Outcomes (2017) 15(1):197. doi: 10.1186/s12955-017-0773-y

16. Fontaine KR, Redden DT, Wang C, Westfall AO, Allison DB. Years of Life Lost Due to Obesity. Jama (2003) 289(2):187-93. doi: 10.1001/jama.289.2.187

17. Conway B, Rene A. Obesity as a Disease: No Lightweight Matter. Obes Rev (2004) 5(3):145-51. doi: 10.1111/j.1467-789X.2004.00144.x

\section{SUPPLEMENTARY MATERIAL}

The Supplementary Material for this article can be found online at: https://www.frontiersin.org/articles/10.3389/fendo.2021. 778737/full\#supplementary-material

18. Bray GA. Medical Consequences of Obesity. J Clin Endocrinol Metab (2004) 89(6):2583-9. doi: 10.1210/jc.2004-0535

19. Keith SW, Redden DT, Katzmarzyk PT, Boggiano MM, Hanlon EC, Benca RM, et al. Putative Contributors to the Secular Increase in Obesity: Exploring the Roads Less Traveled. Int JObes (Lond) (2006) 30(11):1585-94. doi: 10.1038/sj.ijo.0803326

20. Bray GA, Champagne CM. Beyond Energy Balance: There Is More to Obesity Than Kilocalories. J Am Diet Assoc (2005) 105(5 Suppl 1):S17-23. doi: $10.1016 /$ j.jada.2005.02.018

21. Eisenmann JC. Insight Into the Causes of the Recent Secular Trend in Pediatric Obesity: Common Sense Does Not Always Prevail for Complex Multi-Factorial Phenotypes. Prev Med (2006) 42(5):329-35. doi: 10.1016/ j.ypmed.2006.02.002

22. Patterson WB, Glasson J, Naik N, Jones RB, Berger PK, Plows JF, et al. Prenatal Exposure to Ambient Air Pollutants and Early Infant Growth and Adiposity in the Southern California Mother's Milk Study. Environ Health (2021) 20(1):67. doi: 10.1186/s12940-021-00753-8

23. Liu M, Tang W, Zhang Y, Wang Y, Baima K, Li Y, et al. Urban-Rural Differences in the Association Between Long-Term Exposure to Ambient Air Pollution and Obesity in China. Environ Res (2021) 201:111597. doi: 10.1016/j.envres.2021.111597

24. Bowe B, Gibson AK, Xie Y, Yan Y, Donkelaar AV, Martin RV, et al. Ambient Fine Particulate Matter Air Pollution and Risk of Weight Gain and Obesity in United States Veterans: An Observational Cohort Study. Environ Health Perspect (2021) 129(4):47003. doi: 10.1289/ehp7944

25. Zhong Q, Qin QR, Yang WJ, He JL, Zhu JL, Zhu ZY, et al. Multiple Metal Exposure and Obesity: A Prospective Cohort Study of Adults Living Along the Yangtze River, China. Environ Pollut (2021) 285:117150. doi: 10.1016/ j.envpol.2021.117150

26. Jia P, Cao X, Yang H, Dai S, He P, Huang G, et al. Green Space Access in the Neighbourhood and Childhood Obesity. Obes Rev (2021) 22 Suppl 1(Suppl 1):e13100. doi: 10.1111/obr.13100

27. Foraster M, Eze IC, Vienneau D, Schaffner E, Jeong A, Héritier H, et al. Long-Term Exposure to Transportation Noise and Its Association With Adiposity Markers and Development of Obesity. Environ Int (2018) 121(Pt 1):879-89. doi: 10.1016/j.envint.2018.09.057

28. Berger K, Hyland C, Ames JL, Mora AM, Huen K, Eskenazi B, et al. Prenatal Exposure to Mixtures of Phthalates, Parabens, and Other Phenols and Obesity in Five-Year-Olds in the CHAMACOS Cohort. Int J Environ Res Public Health (2021) 18(4):1796. doi: 10.3390/ijerph18041796

29. Wang X, Mukherjee B, Park SK. Associations of Cumulative Exposure to Heavy Metal Mixtures With Obesity and its Comorbidities Among US Adults in NHANES 2003-2014. Environ Int (2018) 121(Pt 1):683-94. doi: 10.1016/j.envint.2018.09.035

30. Pyko A, Eriksson C, Lind T, Mitkovskaya N, Wallas A, Ögren M, et al. Long-Term Exposure to Transportation Noise in Relation to Development of Obesity-a Cohort Study. Environ Health Perspect (2017) 125(11):117005. doi: 10.1289/ehp1910

31. Shao W, Xu J, Xu C, Weng Z, Liu Q, Zhang X, et al. Early-Life Perfluorooctanoic Acid Exposure Induces Obesity in Male Offspring and the Intervention Role of Chlorogenic Acid. Environ Pollut (2021) 272:115974. doi: 10.1016/j.envpol.2020.115974

32. Grün F, Blumberg B. Perturbed Nuclear Receptor Signaling by Environmental Obesogens as Emerging Factors in the Obesity Crisis. Rev Endocr Metab Disord (2007) 8(2):161-71. doi: 10.1007/s11154-007-9049-x

33. Meeker JD. Exposure to Environmental Endocrine Disruptors and Child Development. Arch Pediatr Adolesc Med (2012) 166(10):952-8. doi: 10.1001/ archpediatrics.2012.241

34. Jacobson MH, Woodward M, Bao W, Liu B, Trasande L. Urinary Bisphenols and Obesity Prevalence Among US Children and Adolescents. J Endocr Soc (2019) 3(9):1715-26. doi: 10.1210/js.2019-00201 
35. Arbuckle TE, Davis K, Marro L, Fisher M, Legrand M, LeBlanc A, et al. Phthalate and Bisphenol A Exposure Among Pregnant Women in Canadaresults From the MIREC Study. Environ Int (2014) 68:55-65. doi: 10.1016/ j.envint.2014.02.010

36. González-Mariño I, Ares L, Montes R, Rodil R, Cela R, López-García E, et al. Assessing Population Exposure to Phthalate Plasticizers in Thirteen Spanish Cities Through the Analysis of Wastewater. J Hazard Mater (2021) 401:123272. doi: 10.1016/j.jhazmat.2020.123272

37. Katsikantami I, Sifakis S, Tzatzarakis MN, Vakonaki E, Kalantzi OI, Tsatsakis AM, et al. A Global Assessment of Phthalates Burden and Related Links to Health Effects. Environ Int (2016) 97:212-36. doi: 10.1016/j.envint.2016.09.013

38. Vizcaino E, Grimalt JO, Fernández-Somoano A, Tardon A. Transport of Persistent Organic Pollutants Across the Human Placenta. Environ Int (2014) 65:107-15. doi: 10.1016/j.envint.2014.01.004

39. Ahrens L, Bundschuh M. Fate and Effects of Poly- and Perfluoroalkyl Substances in the Aquatic Environment: A Review. Environ Toxicol Chem (2014) 33(9):1921-9. doi: 10.1002/etc.2663

40. Kim D, Ryu HY, Lee JH, Lee JH, Lee YJ, Kim HK, et al. Organochlorine Pesticides and Polychlorinated Biphenyls in Korean Human Milk: Contamination Levels and Infant Risk Assessment. J Environ Sci Health B (2013) 48(4):243-50. doi: 10.1080/03601234.2013.742413

41. Carwile JL, Michels KB. Urinary Bisphenol A and Obesity: NHANES 20032006. Environ Res (2011) 111(6):825-30. doi: 10.1016/j.envres.2011.05.014

42. Krysiak-Baltyn K, Toppari J, Skakkebaek NE, Jensen TS, Virtanen HE, Schramm KW, et al. Country-Specific Chemical Signatures of Persistent Environmental Compounds in Breast Milk. Int J Androl (2010) 33(2):270-8. doi: 10.1111/j.1365-2605.2009.00996.x

43. Fäys F, Hardy EM, Palazzi P, Haan S, Beausoleil C, Appenzeller BMR. Biomonitoring of Fast-Elimination Endocrine Disruptors - Results From a 6-Month Follow Up on Human Volunteers With Repeated Urine and Hair Collection. Sci Total Environ (2021) 778:146330. doi: 10.1016/ j.scitotenv.2021.146330

44. Cao Z, Lin S, Zhao F, Lv Y, Qu Y, Hu X, et al. Cohort Profile: China National Human Biomonitoring (CNHBM)-A Nationally Representative, Prospective Cohort in Chinese Population. Environ Int (2021) 146:106252. doi: 10.1016/ j.envint.2020.106252

45. Pollock T, Karthikeyan S, Walker M, Werry K, St-Amand A. Trends in Environmental Chemical Concentrations in the Canadian Population: Biomonitoring Data From the Canadian Health Measures Survey 20072017. Environ Int (2021) 155:106678. doi: 10.1016/j.envint.2021.106678

46. Karrer C, Andreassen M, von Goetz N, Sonnet F, Sakhi AK, Hungerbühler $\mathrm{K}$, et al. The EuroMix Human Biomonitoring Study: Source-To-Dose Modeling of Cumulative and Aggregate Exposure for the Bisphenols BPA, BPS, and BPF and Comparison With Measured Urinary Levels. Environ Int (2020) 136:105397. doi: 10.1016/j.envint.2019.105397

47. Jeon HL, Hong S, Choi K, Lee C, Yoo J. First Nationwide Exposure Profile of Major Persistent Organic Pollutants Among Korean Adults and Their Determinants: Korean National Environmental Health Survey Cycle 3 (2015-2017). Int J Hyg Environ Health (2021) 236:113779. doi: 10.1016/ j.ijheh.2021.113779

48. Zhang Y, Dong T, Hu W, Wang X, Xu B, Lin Z, et al. Association Between Exposure to a Mixture of Phenols, Pesticides, and Phthalates and Obesity: Comparison of Three Statistical Models. Environ Int (2019) 123:325-36. doi: 10.1016/j.envint.2018.11.076

49. Li YL, Lv J, Du ZP, Feng S, Sheng J, Jin ZX, et al. The Levels of Phthalate Exposure and Associations With Obesity in an Elderly Population in China. Ecotoxicol Environ Saf (2020) 201:110749. doi: 10.1016/j.ecoenv.2020.110749

50. Sol CM, Santos S, Duijts L, Asimakopoulos AG, Martinez-Moral MP, Kannan K, et al. Fetal Exposure to Phthalates and Bisphenols and Childhood General and Organ Fat. A Population-Based Prospective Cohort Study. Int J Obes (Lond) (2020) 44(11):2225-35. doi: 10.1038/ s41366-020-00672-7

51. Jensen RC, Andersen MS, Larsen PV, Glintborg D, Dalgård C, Timmermann CAG, et al. Prenatal Exposures to Perfluoroalkyl Acids and Associations With Markers of Adiposity and Plasma Lipids in Infancy: An Odense Child Cohort Study. Environ Health Perspect (2020) 128(7):77001. doi: 10.1289/ ehp5184
52. Egusquiza RJ, Blumberg B. Environmental Obesogens and Their Impact on Susceptibility to Obesity: New Mechanisms and Chemicals. Endocrinology (2020) 161(3):1-14. doi: 10.1210/endocr/bqaa024

53. Wu W, Li M, Liu A, Wu C, Li D, Deng Q, et al. Bisphenol A and the Risk of Obesity a Systematic Review With Meta-Analysis of the Epidemiological Evidence. Dose Response (2020) 18(2):1559325820916949. doi: 10.1177/ 1559325820916949

54. Cano-Sancho G, Salmon AG, La Merrill MA. Association Between Exposure to $\mathrm{P}, \mathrm{P}^{\prime}-\mathrm{DDT}$ and Its Metabolite P,P'-DDE With Obesity: Integrated Systematic Review and Meta-Analysis. Environ Health Perspect (2017) 125 (9):096002. doi: 10.1289/ehp527

55. Wassenaar PNH, Trasande L, Legler J. Systematic Review and Meta-Analysis of Early-Life Exposure to Bisphenol A and Obesity-Related Outcomes in Rodents. Environ Health Perspect (2017) 125(10):106001. doi: 10.1289/ ehp1233

56. de Cock M, van de Bor M. Obesogenic Effects of Endocrine Disruptors, What do We Know From Animal and Human Studies? Environ Int (2014) 70:15-24. doi: 10.1016/j.envint.2014.04.022

57. Goodman M, Lakind JS, Mattison DR. Do Phthalates Act as Obesogens in Humans? A Systematic Review of the Epidemiological Literature. Crit Rev Toxicol (2014) 44(2):151-75. doi: 10.3109/10408444.2013.860076

58. Kim SH, Park MJ. Phthalate Exposure and Childhood Obesity. Ann Pediatr Endocrinol Metab (2014) 19(2):69-75. doi: 10.6065/apem.2014.19.2.69

59. Karoutsou E, Polymeris A. Environmental Endocrine Disruptors and Obesity. Endocr Regul (2012) 46(1):37-46. doi: 10.4149/endo_2012_01_37

60. Kail R. Children and Their Development. 6th Edition. Englewood Cliffs, N.J; Prentice Hall (2011).

61. Braun JM, Li N, Arbuckle TE, Dodds L, Massarelli I, Fraser WD, et al. Association Between Gestational Urinary Bisphenol a Concentrations and Adiposity in Young Children: The MIREC Study. Environ Res (2019) 172:454-61. doi: 10.1016/j.envres.2019.02.038

62. Amin MM, Ebrahim K, Hashemi M, Shoshtari-Yeganeh B, Rafiei N, Mansourian M, et al. Association of Exposure to Bisphenol A With Obesity and Cardiometabolic Risk Factors in Children and Adolescents. Int J Environ Health Res (2019) 29(1):94-106. doi: 10.1080/ 09603123.2018.1515896

63. Okubo Y, Handa A, Belin T. Serial Cross-Sectional Study for the Association Between Urinary Bisphenol A and Paediatric Obesity: Recent Updates Using NHANES 2003-2014. Pediatr Obes (2019) 14(12):e12566. doi: 10.1111/ ijpo. 12566

64. Do MT, Chang VC, Mendez MA, de Groh M. Urinary Bisphenol A and Obesity in Adults: Results From the Canadian Health Measures Survey. Health Promot Chronic Dis Prev Can (2017) 37(12):403-12. doi: 10.24095/ hpcdp.37.12.02

65. Hong SH, Sung YA, Hong YS, Ha E, Jeong K, Chung H, et al. Urinary Bisphenol A is Associated With Insulin Resistance and Obesity in Reproductive-Aged Women. Clin Endocrinol (Oxf) (2017) 86(4):506-12. doi: $10.1111 /$ cen.13270

66. Li J, Lai H, Chen S, Zhu H, Lai S. Gender Differences in the Associations Between Urinary Bisphenol A and Body Composition Among American Children: The National Health and Nutrition Examination Survey, 20032006. J Epidemiol (2017) 27(5):228-34. doi: 10.1016/j.je.2016.12.001

67. Liu B, Lehmler HJ, Sun Y, Xu G, Liu Y, Zong G, et al. Bisphenol A Substitutes and Obesity in US Adults: Analysis of a Population-Based, Cross-Sectional Study. Lancet Planet Health (2017) 1(3):e114-22. doi: 10.1016/s2542-5196 (17)30049-9

68. Deierlein AL, Wolff MS, Pajak A, Pinney SM, Windham GC, Galvez MP, et al. Phenol Concentrations During Childhood and Subsequent Measures of Adiposity Among Young Girls. Am J Epidemiol (2017) 186(5):581-92. doi: 10.1093/aje/kwx136

69. Hao M, Ding L, Xuan L, Wang T, Li M, Zhao Z, et al. Urinary Bisphenol A Concentration and the Risk of Central Obesity in Chinese Adults: A Prospective Study. J Diabetes (2018) 10(6):442-8. doi: 10.1111/17530407.12531

70. Yang TC, Peterson KE, Meeker JD, Sánchez BN, Zhang Z, Cantoral A, et al. Bisphenol A and Phthalates In Utero and in Childhood: Association With Child BMI Z-Score and Adiposity. Environ Res (2017) 156:326-33. doi: 10.1016/j.envres.2017.03.038 
71. Buckley JP, Herring AH, Wolff MS, Calafat AM, Engel SM. Prenatal Exposure to Environmental Phenols and Childhood Fat Mass in the Mount Sinai Children's Environmental Health Study. Environ Int (2016) 91:350-6. doi: 10.1016/j.envint.2016.03.019

72. Hoepner LA, Whyatt RM, Widen EM, Hassoun A, Oberfield SE, Mueller NT, et al. Bisphenol A and Adiposity in an Inner-City Birth Cohort. Environ Health Perspect (2016) 124(10):1644-50. doi: 10.1289/ehp205

73. Vafeiadi M, Roumeliotaki T, Myridakis A, Chalkiadaki G, Fthenou E, Dermitzaki E, et al. Association of Early Life Exposure to Bisphenol A With Obesity and Cardiometabolic Traits in Childhood. Environ Res (2016) 146:379-87. doi: 10.1016/j.envres.2016.01.017

74. Lee MR, Kim JH, Choi YH, Bae S, Park C, Hong YC. Association of Bisphenol A Exposure With Overweight in the Elderly: A Panel Study. Environ Sci Pollut Res Int (2015) 22(12):9370-7. doi: 10.1007/s11356-0154087-5

75. Andra SS, Makris KC. Association Between Urinary Levels of Bisphenol A and its Monochlorinated Derivative and Obesity. J Environ Sci Health A Tox Hazard Subst Environ Eng (2015) 50(11):1169-79. doi: 10.1080/ 10934529.2015.1047674

76. Savastano S, Tarantino G, D'Esposito V, Passaretti F, Cabaro S, Liotti A, et al. Bisphenol-A Plasma Levels are Related to Inflammatory Markers, Visceral Obesity and Insulin-Resistance: A Cross-Sectional Study on Adult Male Population. J Transl Med (2015) 13:169. doi: 10.1186/s12967-015-0532-y

77. Ko A, Hwang MS, Park JH, Kang HS, Lee HS, Hong JH. Association Between Urinary Bisphenol A and Waist Circumference in Korean Adults. Toxicol Res (2014) 30(1):39-44. doi: 10.5487/tr.2014.30.1.039

78. Braun JM, Lanphear BP, Calafat AM, Deria S, Khoury J, Howe CJ, et al. Early-Life Bisphenol a Exposure and Child Body Mass Index: A Prospective Cohort Study. Environ Health Perspect (2014) 122(11):1239-45. doi: 10.1289/ehp. 1408258

79. Harley KG, Aguilar Schall R, Chevrier J, Tyler K, Aguirre H, Bradman A, et al. Prenatal and Postnatal Bisphenol A Exposure and Body Mass Index in Childhood in the CHAMACOS Cohort. Environ Health Perspect (2013) 121 (4):514-20. doi: 10.1289/ehp.1205548

80. Valvi D, Casas M, Mendez MA, Ballesteros-Gómez A, Luque N, Rubio S, et al. Prenatal Bisphenol a Urine Concentrations and Early Rapid Growth and Overweight Risk in the Offspring. Epidemiology (2013) 24(6):791-9. doi: 10.1097/EDE.0b013e3182a67822

81. Li DK, Miao M, Zhou Z, Wu C, Shi H, Liu X, et al. Urine Bisphenol-A Level in Relation to Obesity and Overweight in School-Age Children. PloS One (2013) 8(6):e65399. doi: 10.1371/journal.pone.0065399

82. Bhandari R, Xiao J, Shankar A. Urinary Bisphenol A and Obesity in US Children. Am J Epidemiol (2013) 177(11):1263-70. doi: 10.1093/aje/kws391

83. Trasande L, Attina TM, Blustein J. Association Between Urinary Bisphenol A Concentration and Obesity Prevalence in Children and Adolescents. Jama (2012) 308(11):1113-21. doi: 10.1001/2012.jama.11461

84. Wang T, Li M, Chen B, Xu M, Xu Y, Huang Y, et al. Urinary Bisphenol A (BPA) Concentration Associates With Obesity and Insulin Resistance. J Clin Endocrinol Metab (2012) 97(2):E223-7. doi: 10.1210/jc.2011-1989

85. Wang HX, Zhou Y, Tang CX, Wu JG, Chen Y, Jiang QW. Association Between Bisphenol A Exposure and Body Mass Index in Chinese School Children: A Cross-Sectional Study. Environ Health (2012) 11:79. doi: 10.1186/1476-069x-11-79

86. Shankar A, Teppala S, Sabanayagam C. Urinary Bisphenol a Levels and Measures of Obesity: Results From the National Health and Nutrition Examination Survey 2003-2008. ISRN Endocrinol (2012) 2012:965243. doi: 10.5402/2012/965243

87. Bowman A, Peterson KE, Dolinoy DC, Meeker JD, Sánchez BN, MercadoGarcia A, et al. Phthalate Exposures, DNA Methylation and Adiposity in Mexican Children Through Adolescence. Front Public Health (2019) 7:162. doi: 10.3389/fpubh.2019.00162

88. Kang Y, Park J, Youn K. Association Between Urinary Phthalate Metabolites and Obesity in Adult Korean Population: Korean National Environmental Health Survey (KoNEHS), 2012-2014. Ann Occup Environ Med (2019) 31: e23. doi: 10.35371/aoem.2019.31.e23

89. Amin MM, Ebrahimpour K, Parastar S, Shoshtari-Yeganeh B, Hashemi M, Mansourian M, et al. Association of Urinary Concentrations of Phthalate Metabolites With Cardiometabolic Risk Factors and Obesity in Children and
Adolescents. Chemosphere (2018) 211:547-56. doi: 10.1016/ j.chemosphere.2018.07.172

90. Kim SH, On JW, Pyo H, Ko KS, Won JC, Yang J, et al. Percentage Fractions of Urinary Di(2-Ethylhexyl) Phthalate Metabolites: Association With Obesity and Insulin Resistance in Korean Girls. PloS One (2018) 13(11): e0208081. doi: 10.1371/journal.pone.0208081

91. Xia B, Zhu Q, Zhao Y, Ge W, Zhao Y, Song Q, et al. Phthalate Exposure and Childhood Overweight and Obesity: Urinary Metabolomic Evidence. Environ Int (2018) 121(Pt 1):159-68. doi: 10.1016/j.envint.2018.09.001

92. Amin MM, Parastar S, Ebrahimpour K, Shoshtari-Yeganeh B, Hashemi M, Mansourian M, et al. Association of Urinary Phthalate Metabolites Concentrations With Body Mass Index and Waist Circumference. Environ Sci Pollut Res Int (2018) 25(11):11143-51. doi: 10.1007/s11356-018-1413-8

93. Vafeiadi M, Myridakis A, Roumeliotaki T, Margetaki K, Chalkiadaki G, Dermitzaki E, et al. Association of Early Life Exposure to Phthalates With Obesity and Cardiometabolic Traits in Childhood: Sex Specific Associations. Front Public Health (2018) 6:327. doi: 10.3389/fpubh.2018.00327

94. Wu W, Wu P, Yang F, Sun DL, Zhang DX, Zhou YK. Association of Phthalate Exposure With Anthropometric Indices and Blood Pressure in First-Grade Children. Environ Sci Pollut Res Int (2018) 25(23):23125-34. doi: 10.1007/s11356-018-2447-7

95. Harley KG, Berger K, Rauch S, Kogut K, Claus Henn B, Calafat AM, et al. Association of Prenatal Urinary Phthalate Metabolite Concentrations and Childhood BMI and Obesity. Pediatr Res (2017) 82(3):405-15. doi: 10.1038/ pr.2017.112

96. Shoaff J, Papandonatos GD, Calafat AM, Ye X, Chen A, Lanphear BP, et al. Early-Life Phthalate Exposure and Adiposity at 8 Years of Age. Environ Health Perspect (2017) 125(9):097008. doi: 10.1289/ehp1022

97. Dong R, Zhou T, Chen J, Zhang M, Zhang H, Wu M, et al. Gender- and AgeSpecific Relationships Between Phthalate Exposures and Obesity in Shanghai Adults. Arch Environ Contam Toxicol (2017) 73(3):431-41. doi: 10.1007/ s00244-017-0441-6

98. Buckley JP, Engel SM, Mendez MA, Richardson DB, Daniels JL, Calafat AM, et al. Prenatal Phthalate Exposures and Childhood Fat Mass in a New York City Cohort. Environ Health Perspect (2016) 124(4):507-13. doi: 10.1289/ ehp. 1509788

99. Buckley JP, Engel SM, Braun JM, Whyatt RM, Daniels JL, Mendez MA, et al. Prenatal Phthalate Exposures and Body Mass Index Among 4- to 7-YearOld Children: A Pooled Analysis. Epidemiology (2016) 27(3):449-58. doi: 10.1097/ede.0000000000000436

100. Kim JH, Park H, Lee J, Cho G, Choi S, Choi G, et al. Association of Diethylhexyl Phthalate With Obesity-Related Markers and Body Mass Change From Birth to 3 Months of Age. J Epidemiol Community Health (2016) 70(5):466-72. doi: 10.1136/jech-2015-206315

101. Maresca MM, Hoepner LA, Hassoun A, Oberfield SE, Mooney SJ, Calafat AM, et al. Prenatal Exposure to Phthalates and Childhood Body Size in an Urban Cohort. Environ Health Perspect (2016) 124(4):514-20. doi: 10.1289/ ehp. 1408750

102. Deierlein AL, Wolff MS, Pajak A, Pinney SM, Windham GC, Galvez MP, et al. Longitudinal Associations of Phthalate Exposures During Childhood and Body Size Measurements in Young Girls. Epidemiology (2016) 27 (4):492-9. doi: 10.1097/ede.0000000000000489

103. Agay-Shay K, Martinez D, Valvi D, Garcia-Esteban R, Basagaña X, Robinson $\mathrm{O}$, et al. Exposure to Endocrine-Disrupting Chemicals During Pregnancy and Weight at 7 Years of Age: A Multi-Pollutant Approach. Environ Health Perspect (2015) 123(10):1030-7. doi: 10.1289/ehp.1409049

104. Yaghjyan L, Sites S, Ruan Y, Chang SH. Associations of Urinary Phthalates With Body Mass Index, Waist Circumference and Serum Lipids Among Females: National Health and Nutrition Examination Survey 1999-2004. Int J Obes (Lond) (2015) 39(6):994-1000. doi: 10.1038/ijo.2015.8

105. Hou JW, Lin CL, Tsai YA, Chang CH, Liao KW, Yu CJ, et al. The Effects of Phthalate and Nonylphenol Exposure on Body Size and Secondary Sexual Characteristics During Puberty. Int J Hyg Environ Health (2015) 218(7):60315. doi: 10.1016/j.ijheh.2015.06.004

106. Buser MC, Murray HE, Scinicariello F. Age and Sex Differences in Childhood and Adulthood Obesity Association With Phthalates: Analyses of NHANES 2007-2010. Int J Hyg Environ Health (2014) 217(6):687-94. doi: 10.1016/ j.ijheh.2014.02.005 
107. Zhang Y, Meng X, Chen L, Li D, Zhao L, Zhao Y, et al. Age and Sex-Specific Relationships Between Phthalate Exposures and Obesity in Chinese Children at Puberty. PloS One (2014) 9(8):e104852. doi: 10.1371/journal. pone. 0104852

108. Trasande L, Attina TM, Sathyanarayana S, Spanier AJ, Blustein J. Race/ ethnicity-Specific Associations of Urinary Phthalates With Childhood Body Mass in a Nationally Representative Sample. Environ Health Perspect (2013) 121(4):501-6. doi: 10.1289/ehp.1205526

109. Wang H, Zhou Y, Tang C, He Y, Wu J, Chen Y, et al. Urinary Phthalate Metabolites are Associated With Body Mass Index and Waist Circumference in Chinese School Children. PloS One (2013) 8(2):e56800. doi: 10.1371/ journal.pone. 0056800

110. Teitelbaum SL, Mervish N, Moshier EL, Vangeepuram N, Galvez MP, Calafat AM, et al. Associations Between Phthalate Metabolite Urinary Concentrations and Body Size Measures in New York City Children. Environ Res (2012) 112:186-93. doi: 10.1016/j.envres.2011.12.006

111. Hatch EE, Nelson JW, Qureshi MM, Weinberg J, Moore LL, Singer M, et al. Association of Urinary Phthalate Metabolite Concentrations With Body Mass Index and Waist Circumference: A Cross-Sectional Study of NHANES Data, 1999-2002. Environ Health (2008) 7:27. doi: 10.1186/1476-069x-7-27

112. Stahlhut RW, van Wijngaarden E, Dye TD, Cook S, Swan SH. Concentrations of Urinary Phthalate Metabolites are Associated With Increased Waist Circumference and Insulin Resistance in Adult US Males. Environ Health Perspect (2007) 115(6):876-82. doi: 10.1289/ehp.9882

113. Chen Q, Zhang X, Zhao Y, Lu W, Wu J, Zhao S, et al. Prenatal Exposure to Perfluorobutanesulfonic Acid and Childhood Adiposity: A Prospective Birth Cohort Study in Shanghai, China. Chemosphere (2019) 226:17-23. doi: 10.1016/j.chemosphere.2019.03.095

114. Vuong AM, Braun JM, Wang Z, Yolton K, Xie C, Sjodin A, et al. Exposure to Polybrominated Diphenyl Ethers (PBDEs) During Childhood and Adiposity Measures at Age 8 Years. Environ Int (2019) 123:148-55. doi: 10.1016/ j.envint.2018.11.050

115. Lauritzen HB, Larose TL, Øien T, Sandanger TM, Odland J, van de Bor M, et al. Prenatal Exposure to Persistent Organic Pollutants and Child Overweight/Obesity at 5-Year Follow-Up: A Prospective Cohort Study. Environ Health (2018) 17(1):9. doi: 10.1186/s12940-017-0338-x

116. Coker E, Chevrier J, Rauch S, Bradman A, Obida M, Crause M, et al. Association Between Prenatal Exposure to Multiple Insecticides and Child Body Weight and Body Composition in the VHEMBE South African Birth Cohort. Environ Int (2018) 113:122-32. doi: 10.1016/j.envint.2018.01.016

117. Warner M, Rauch S, Coker ES, Harley K, Kogut K, Sjödin A, et al. Obesity in Relation to Serum Persistent Organic Pollutant Concentrations in CHAMACOS Women. Environ Epidemiol (2018) 2(4):e032. doi: 10.1097/ ee 9.0000000000000032

118. Warner M, Ye M, Harley K, Kogut K, Bradman A, Eskenazi B. Prenatal DDT Exposure and Child Adiposity at Age 12: The CHAMACOS Study. Environ Res (2017) 159:606-12. doi: 10.1016/j.envres.2017.08.050

119. Henríquez-Hernández LA, Luzardo OP, Valerón PF, Zumbado M, SerraMajem L, Camacho M, et al. Persistent Organic Pollutants and Risk of Diabetes and Obesity on Healthy Adults: Results From a Cross-Sectional Study in Spain. Sci Total Environ (2017) 607-608:1096-102. doi: 10.1016/ j.scitotenv.2017.07.075

120. Mora AM, Oken E, Rifas-Shiman SL, Webster TF, Gillman MW, Calafat AM, et al. Prenatal Exposure to Perfluoroalkyl Substances and Adiposity in Early and Mid-Childhood. Environ Health Perspect (2017) 125(3):467-73. doi: $10.1289 / \mathrm{ehp} 246$

121. Karlsen M, Grandjean P, Weihe P, Steuerwald U, Oulhote Y, Valvi D. EarlyLife Exposures to Persistent Organic Pollutants in Relation to Overweight in Preschool Children. Reprod Toxicol (2017) 68:145-53. doi: 10.1016/ j.reprotox.2016.08.002

122. Braun JM, Chen A, Romano ME, Calafat AM, Webster GM, Yolton K, et al. Prenatal Perfluoroalkyl Substance Exposure and Child Adiposity at 8 Years of Age: The HOME Study. Obesity (Silver Spring) (2016) 24(1):231-7. doi: $10.1002 /$ oby. 21258

123. Vuong AM, Braun JM, Sjödin A, Webster GM, Yolton K, Lanphear BP, et al. Prenatal Polybrominated Diphenyl Ether Exposure and Body Mass Index in Children Up To 8 Years of Age. Environ Health Perspect (2016) 124 (12):1891-7. doi: 10.1289/ehp139
124. Høyer BB, Ramlau-Hansen CH, Vrijheid M, Valvi D, Pedersen HS, Zviezdai $\mathrm{V}$, et al. Anthropometry in 5- to 9-Year-Old Greenlandic and Ukrainian Children in Relation to Prenatal Exposure to Perfluorinated Alkyl Substances. Environ Health Perspect (2015) 123(8):841-6. doi: 10.1289/ ehp. 1408881

125. Tang-Péronard JL, Jensen TK, Andersen HR, Ried-Larsen M, Grøntved A, Andersen LB, et al. Associations Between Exposure to Persistent Organic Pollutants in Childhood and Overweight Up to 12 Years Later in a Low Exposed Danish Population. Obes Facts (2015) 8(4):282-92. doi: 10.1159/ 000438834

126. Vafeiadi M, Georgiou V, Chalkiadaki G, Rantakokko P, Kiviranta H, Karachaliou M, et al. Association of Prenatal Exposure to Persistent Organic Pollutants With Obesity and Cardiometabolic Traits in Early Childhood: The Rhea Mother-Child Cohort (Crete, Greece). Environ Health Perspect (2015) 123(10):1015-21. doi: 10.1289/ehp.1409062

127. Erkin-Cakmak A, Harley KG, Chevrier J, Bradman A, Kogut K, Huen K, et al. In Utero and Childhood Polybrominated Diphenyl Ether Exposures and Body Mass at Age 7 Years: The CHAMACOS Study. Environ Health Perspect (2015) 123(6):636-42. doi: 10.1289/ehp.1408417

128. Zong G, Grandjean P, Wu H, Sun Q. Circulating Persistent Organic Pollutants and Body Fat Distribution: Evidence From NHANES 19992004. Obesity (Silver Spring) (2015) 23(9):1903-10. doi: 10.1002/oby.21161

129. Delvaux I, Van Cauwenberghe J, Den Hond E, Schoeters G, Govarts E, Nelen V, et al. Prenatal Exposure to Environmental Contaminants and Body Composition at Age 7-9 Years. Environ Res (2014) 132:24-32. doi: 10.1016/j.envres.2014.03.019

130. Tang-Péronard JL, Heitmann BL, Andersen HR, Steuerwald U, Grandjean P, Weihe P, et al. Association Between Prenatal Polychlorinated Biphenyl Exposure and Obesity Development at Ages 5 and 7 Y: A Prospective Cohort Study of 656 Children From the Faroe Islands. Am J Clin Nutr (2014) 99(1):5-13. doi: 10.3945/ajen.113.066720

131. Dirinck EL, Dirtu AC, Govindan M, Covaci A, Van Gaal LF, Jorens PG. Exposure to Persistent Organic Pollutants: Relationship With Abnormal Glucose Metabolism and Visceral Adiposity. Diabetes Care (2014) 37 (7):1951-8. doi: 10.2337/dc13-2329

132. Valvi D, Mendez MA, Garcia-Esteban R, Ballester F, Ibarluzea J, Goñi F, et al. Prenatal Exposure to Persistent Organic Pollutants and Rapid Weight Gain and Overweight in Infancy. Obesity (Silver Spring) (2014) 22(2):488-96. doi: 10.1002/oby.20603

133. Høyer BB, Ramlau-Hansen CH, Henriksen TB, Pedersen HS, Góralczyk K, Zviezdai V, et al. Body Mass Index in Young School-Age Children in Relation to Organochlorine Compounds in Early Life: A Prospective Study. Int J Obes (Lond) (2014) 38(7):919-25. doi: 10.1038/ijo.2014.58

134. Warner M, Wesselink A, Harley KG, Bradman A, Kogut K, Eskenazi B. Prenatal Exposure to Dichlorodiphenyltrichloroethane and Obesity at 9 Years of Age in the CHAMACOS Study Cohort. Am J Epidemiol (2014) 179(11):1312-22. doi: 10.1093/aje/kwu046

135. Warner M, Aguilar Schall R, Harley KG, Bradman A, Barr D, Eskenazi B. In Utero DDT and DDE Exposure and Obesity Status of 7-Year-Old MexicanAmerican Children in the CHAMACOS Cohort. Environ Health Perspect (2013) 121(5):631-6. doi: 10.1289/ehp.1205656

136. Cupul-Uicab LA, Klebanoff MA, Brock JW, Longnecker MP. Prenatal Exposure to Persistent Organochlorines and Childhood Obesity in the US Collaborative Perinatal Project. Environ Health Perspect (2013) 121(9):11039. doi: 10.1289/ehp.1205901

137. Andersen CS, Fei C, Gamborg M, Nohr EA, Sørensen TI, Olsen J. Prenatal Exposures to Perfluorinated Chemicals and Anthropometry at 7 Years of Age. Am J Epidemiol (2013) 178(6):921-7. doi: 10.1093/aje/kwt057

138. Halldorsson TI, Rytter D, Haug LS, Bech BH, Danielsen I, Becher G, et al. Prenatal Exposure to Perfluorooctanoate and Risk of Overweight at 20 Years of Age: A Prospective Cohort Study. Environ Health Perspect (2012) 120 (5):668-73. doi: 10.1289/ehp.1104034

139. Valvi D, Mendez MA, Martinez D, Grimalt JO, Torrent M, Sunyer J, et al. Prenatal Concentrations of Polychlorinated Biphenyls, DDE, and DDT and Overweight in Children: A Prospective Birth Cohort Study. Environ Health Perspect (2012) 120(3):451-7. doi: 10.1289/ehp.1103862

140. De Roos AJ, Ulrich CM, Sjodin A, McTiernan A. Adiposity, Body Composition, and Weight Change in Relation to Organochlorine Pollutant 
Plasma Concentrations. J Expo Sci Environ Epidemiol (2012) 22(6):617-24. doi: $10.1038 /$ jes. 2012.43

141. Lee DH, Lind L, Jacobs DRJr., Salihovic S, van Bavel B, Lind PM. Associations of Persistent Organic Pollutants With Abdominal Obesity in the Elderly: The Prospective Investigation of the Vasculature in Uppsala Seniors (PIVUS) Study. Environ Int (2012) 40:170-8. doi: 10.1016/ j.envint.2011.07.010

142. Mendez MA, Garcia-Esteban R, Guxens M, Vrijheid M, Kogevinas M, Goñi F, et al. Prenatal Organochlorine Compound Exposure, Rapid Weight Gain, and Overweight in Infancy. Environ Health Perspect (2011) 119(2):272-8. doi: 10.1289/ehp.1002169

143. Lee DH, Steffes MW, Sjödin A, Jones RS, Needham LL, Jacobs DRJr. Low Dose Organochlorine Pesticides and Polychlorinated Biphenyls Predict Obesity, Dyslipidemia, and Insulin Resistance Among People Free of Diabetes. PloS One (2011) 6(1):e15977. doi: 10.1371/journal.pone.0015977

144. Dirinck E, Jorens PG, Covaci A, Geens T, Roosens L, Neels H, et al. Obesity and Persistent Organic Pollutants: Possible Obesogenic Effect of Organochlorine Pesticides and Polychlorinated Biphenyls. Obesity (Silver Spring) (2011) 19(4):709-14. doi: 10.1038/oby.2010.133

145. Rönn M, Lind L, van Bavel B, Salihovic S, Michaëlsson K, Lind PM. Circulating Levels of Persistent Organic Pollutants Associate in Divergent Ways to Fat Mass Measured by DXA in Humans. Chemosphere (2011) 85 (3):335-43. doi: 10.1016/j.chemosphere.2011.06.095

146. Andersen CS, Fei C, Gamborg M, Nohr EA, Sørensen TI, Olsen J. Prenatal Exposures to Perfluorinated Chemicals and Anthropometric Measures in Infancy. Am J Epidemiol (2010) 172(11):1230-7. doi: 10.1093/aje/kwq289

147. Karmaus W, Osuch JR, Eneli I, Mudd LM, Zhang J, Mikucki D, et al. Maternal Levels of Dichlorodiphenyl-Dichloroethylene (DDE) may Increase Weight and Body Mass Index in Adult Female Offspring. Occup Environ Med (2009) 66(3):143-9. doi: 10.1136/oem.2008.041921

148. Verhulst SL, Nelen V, Hond ED, Koppen G, Beunckens C, Vael C, et al. Intrauterine Exposure to Environmental Pollutants and Body Mass Index During the First 3 Years of Life. Environ Health Perspect (2009) 117(1):1226. doi: 10.1289/ehp. 0800003

149. Smink A, Ribas-Fito N, Garcia R, Torrent M, Mendez MA, Grimalt JO, et al. Exposure to Hexachlorobenzene During Pregnancy Increases the Risk of Overweight in Children Aged 6 Years. Acta Paediatr (2008) 97(10):1465-9. doi: 10.1111/j.1651-2227.2008.00937.x

150. Kimbro RT, Brooks-Gunn J, McLanahan S. Racial and Ethnic Differentials in Overweight and Obesity Among 3-Year-Old Children. Am J Public Health (2007) 97(2):298-305. doi: 10.2105/ajph.2005.080812

151. Stryjecki C, Alyass A, Meyre D. Ethnic and Population Differences in the Genetic Predisposition to Human Obesity. Obes Rev (2018) 19(1):62-80. doi: 10.1111/obr.12604

152. Czaja K, Ludwicki JK, Góralczyk K, Struciński P. Relationship Between Two Consecutive Lactations and Fat Level in Persistent Organochlorine Compound Concentrations in Human Breast Milk. Chemosphere (2001) 43(4-7):889-93. doi: 10.1016/s0045-6535(00)00449-5

153. Jacobson JL, Fein GG, Jacobson SW, Schwartz PM, Dowler JK. The Transfer of Polychlorinated Biphenyls (PCBs) and Polybrominated Biphenyls (PBBs) Across the Human Placenta and Into Maternal Milk. Am J Public Health (1984) 74(4):378-9. doi: 10.2105/ajph.74.4.378

154. Longnecker MP. Invited Commentary: Why DDT Matters Now. Am J Epidemiol (2005) 162(8):726-8. doi: 10.1093/aje/kwi277

155. Porta $\mathrm{M}$, Puigdomènech E, Ballester F, Selva J, Ribas-Fitó N, Llop $\mathrm{S}$, et al. Monitoring Concentrations of Persistent Organic Pollutants in the General Population: The International Experience. Environ Int (2008) 34(4):546-61. doi: 10.1016/j.envint.2007.10.004

156. Shen H, Main KM, Virtanen HE, Damggard IN, Haavisto AM, Kaleva M, et al. From Mother to Child: Investigation of Prenatal and Postnatal Exposure to Persistent Bioaccumulating Toxicants Using Breast Milk and Placenta Biomonitoring. Chemosphere (2007) 67(9):S256-62. doi: 10.1016/ j.chemosphere.2006.05.106

157. Woodruff T, Wolff MS, Davis DL, Hayward D. Organochlorine Exposure Estimation in the Study of Cancer Etiology. Environ Res (1994) 65(1):13244. doi: 10.1006/enrs.1994.1026

158. Awad R, Zhou Y, Nyberg E, Namazkar S, Yongning W, Xiao Q, et al. Emerging Per- and Polyfluoroalkyl Substances (PFAS) in Human Milk From
Sweden and China. Environ Sci Process Impacts (2020) 22(10):2023-30. doi: 10.1039/d0em00077a

159. Domingo JL, Nadal M. Human Exposure to Per- and Polyfluoroalkyl Substances (PFAS) Through Drinking Water: A Review of the Recent Scientific Literature. Environ Res (2019) 177:108648. doi: 10.1016/j.envres.2019.108648

160. Fromme H, Dreyer A, Dietrich S, Fembacher L, Lahrz T, Völkel W. Neutral Polyfluorinated Compounds in Indoor Air in Germany-the LUPE 4 Study. Chemosphere (2015) 139:572-8. doi: 10.1016/j.chemosphere.2015.07.024

161. Fromme H, Tittlemier SA, Völkel W, Wilhelm M, Twardella D. Perfluorinated Compounds-Exposure Assessment for the General Population in Western Countries. Int J Hyg Environ Health (2009) 212 (3):239-70. doi: 10.1016/j.ijheh.2008.04.007

162. Monroy R, Morrison K, Teo K, Atkinson S, Kubwabo C, Stewart B, et al. Serum Levels of Perfluoroalkyl Compounds in Human Maternal and Umbilical Cord Blood Samples. Environ Res (2008) 108(1):56-62. doi: 10.1016/j.envres.2008.06.001

163. Schecter A, Colacino J, Haffner D, Patel K, Opel M, Päpke O, et al. Perfluorinated Compounds, Polychlorinated Biphenyls, and Organochlorine Pesticide Contamination in Composite Food Samples From Dallas, Texas, USA. Environ Health Perspect (2010) 118(6):796-802. doi: 10.1289/ehp.0901347

164. Czarnota J, Gennings C, Colt JS, De Roos AJ, Cerhan JR, Severson RK, et al. Analysis of Environmental Chemical Mixtures and Non-Hodgkin Lymphoma Risk in the NCI-SEER NHL Study. Environ Health Perspect (2015) 123(10):965-70. doi: 10.1289/ehp.1408630

165. Philips EM, Jaddoe VWV, Asimakopoulos AG, Kannan K, Steegers EAP, Santos S, et al. Bisphenol and Phthalate Concentrations and its Determinants Among Pregnant Women in a Population-Based Cohort in the Netherlands, 2004-5. Environ Res (2018) 161:562-72. doi: 10.1016/j.envres.2017.11.051

166. Lewis RC, Meeker JD, Peterson KE, Lee JM, Pace GG, Cantoral A, et al. Predictors of Urinary Bisphenol A and Phthalate Metabolite Concentrations in Mexican Children. Chemosphere (2013) 93(10):2390-8. doi: 10.1016/ j.chemosphere.2013.08.038

167. Meeker JD, Sathyanarayana S, Swan SH. Phthalates and Other Additives in Plastics: Human Exposure and Associated Health Outcomes. Philos Trans $R$ Soc Lond B Biol Sci (2009) 364(1526):2097-113. doi: 10.1098/rstb.2008.0268

168. Serrano SE, Braun J, Trasande L, Dills R, Sathyanarayana S. Phthalates and Diet: A Review of the Food Monitoring and Epidemiology Data. Environ Health (2014) 13(1):43. doi: 10.1186/1476-069x-13-43

169. Vandenberg LN, Hauser R, Marcus M, Olea N, Welshons WV. Human Exposure to Bisphenol A (BPA). Reprod Toxicol (2007) 24(2):139-77. doi: 10.1016/j.reprotox.2007.07.010

170. Li W, Liu Q, Deng X, Chen Y, Liu S, Story M. Association Between Obesity and Puberty Timing: A Systematic Review and Meta-Analysis. Int J Environ Res Public Health (2017) 14(10):1266. doi: 10.3390/ijerph14101266

171. Mantzoros CS, Rifas-Shiman SL, Williams CJ, Fargnoli JL, Kelesidis T, Gillman MW. Cord Blood Leptin and Adiponectin as Predictors of Adiposity in Children at 3 Years of Age: A Prospective Cohort Study. Pediatrics (2009) 123(2):682-9. doi: 10.1542/peds.2008-0343

172. Aylward LL, Hays SM, Zidek A. Variation in Urinary Spot Sample, $24 \mathrm{H}$ Samples, and Longer-Term Average Urinary Concentrations of Short-Lived Environmental Chemicals: Implications for Exposure Assessment and Reverse Dosimetry. J Expo Sci Environ Epidemiol (2017) 27(6):582-90. doi: 10.1038 /jes.2016.54

173. Grundy SM. Multifactorial Causation of Obesity: Implications for Prevention. Am J Clin Nutr (1998) 67(3 Suppl):563s-72s. doi: 10.1093/ ajcn/67.3.563S

174. Frederiksen H, Kranich SK, Jørgensen N, Taboureau O, Petersen JH, Andersson AM. Temporal Variability in Urinary Phthalate Metabolite Excretion Based on Spot, Morning, and 24-H Urine Samples: Considerations for Epidemiological Studies. Environ Sci Technol (2013) 47 (2):958-67. doi: 10.1021/es303640b

175. Fromme H, Bolte G, Koch HM, Angerer J, Boehmer S, Drexler H, et al. Occurrence and Daily Variation of Phthalate Metabolites in the Urine of an Adult Population. Int J Hyg Environ Health (2007) 210(1):21-33. doi: 10.1016/j.ijheh.2006.09.005

176. Preau JLJr., Wong LY, Silva MJ, Needham LL, Calafat AM. Variability Over 1 Week in the Urinary Concentrations of Metabolites of Diethyl Phthalate and 
Di(2-Ethylhexyl) Phthalate Among Eight Adults: An Observational Study. Environ Health Perspect (2010) 118(12):1748-54. doi: 10.1289/ehp.1002231

177. Ye X, Wong LY, Bishop AM, Calafat AM. Variability of Urinary Concentrations of Bisphenol A in Spot Samples, First Morning Voids, and 24-Hour Collections. Environ Health Perspect (2011) 119(7):983-8. doi: 10.1289/ehp.1002701

178. Biserni M, Mesnage R, Ferro R, Wozniak E, Xenakis T, Mein CA, et al. Quizalofop-P-Ethyl Induces Adipogenesis in 3T3-L1 Adipocytes. Toxicol Sci (2019) 170(2):452-61. doi: 10.1093/toxsci/kfz097

179. Blanco J, Guardia-Escote L, Mulero M, Basaure P, Biosca-Brull J, Cabré M, et al. Obesogenic Effects of Chlorpyrifos and its Metabolites During the Differentiation of 3T3-L1 Preadipocytes. Food Chem Toxicol (2020) 137:111171. doi: 10.1016/j.fct.2020.111171

180. Brulport A, Le Corre L, Chagnon MC. Chronic Exposure of 2,3,7,8Tetrachlorodibenzo-P-Dioxin (TCDD) Induces an Obesogenic Effect in C57BL/6J Mice Fed a High Fat Diet. Toxicology (2017) 390:43-52. doi: 10.1016/j.tox.2017.07.017

181. Chappell VA, Janesick A, Blumberg B, Fenton SE. Tetrabromobisphenol-A Promotes Early Adipogenesis and Lipogenesis in 3T3-L1 Cells. Toxicol Sci (2018) 166(2):332-44. doi: 10.1093/toxsci/kfy209

182. Lee HW, Pyo S. Acrylamide Induces Adipocyte Differentiation and Obesity in Mice. Chem Biol Interact (2019) 298:24-34. doi: 10.1016/j.cbi.2018.10.021

183. Li X, Pham HT, Janesick AS, Blumberg B. Triflumizole Is an Obesogen in Mice That Acts Through Peroxisome Proliferator Activated Receptor Gamma (PPAR $\gamma$ ). Environ Health Perspect (2012) 120(12):1720-6. doi: 10.1289/ehp.1205383

184. Mesnage R, Biserni M, Genkova D, Wesolowski L, Antoniou MN. Evaluation of Neonicotinoid Insecticides for Oestrogenic, Thyroidogenic and
Adipogenic Activity Reveals Imidacloprid Causes Lipid Accumulation. J Appl Toxicol (2018) 38(12):1483-91. doi: 10.1002/jat.3651

185. Smith A, Yu X, Yin L. Diazinon Exposure Activated Transcriptional Factors CCAAT-Enhancer-Binding Proteins $\alpha(\mathrm{C} / \mathrm{Ebp} \alpha)$ and Peroxisome Proliferator-Activated Receptor $\gamma(\operatorname{PPAR} \gamma)$ and Induced Adipogenesis in 3T3-L1 Preadipocytes. Pestic Biochem Physiol (2018) 150:48-58. doi: 10.1016/j.pestbp.2018.07.003

186. Xie X, Yu C, Ren Q, Wen Q, Zhao C, Tang Y, et al. Exposure to HBCD Promotes Adipogenesis Both In Vitro and In Vivo by Interfering With Wnt6 Expression. Sci Total Environ (2020) 705:135917. doi: 10.1016/ j.scitotenv.2019.135917

Conflict of Interest: The authors declare that the research was conducted in the absence of any commercial or financial relationships that could be construed as a potential conflict of interest.

Publisher's Note: All claims expressed in this article are solely those of the authors and do not necessarily represent those of their affiliated organizations, or those of the publisher, the editors and the reviewers. Any product that may be evaluated in this article, or claim that may be made by its manufacturer, is not guaranteed or endorsed by the publisher.

Copyright (๑) 2021 Mohanto, Ito, Kato and Kamijima. This is an open-access article distributed under the terms of the Creative Commons Attribution License (CC BY). The use, distribution or reproduction in other forums is permitted, provided the original author(s) and the copyright owner(s) are credited and that the original publication in this journal is cited, in accordance with accepted academic practice. No use, distribution or reproduction is permitted which does not comply with these terms. 